\title{
Prey deposits and den sites of the Upper Pleistocene hyena Crocuta crocuta spelaea (Goldfuss, 1823) in horizontal and vertical caves of the Bohemian Karst (Czech Republic)
}

\author{
CAJUS G. DIEDRICH \& KAREL ŽÁK
}

\begin{abstract}
Middle and Upper Pleistocene bone accumulations in caves of the Bohemian Karst, Czech Republic, are newly classified as several types of hyena dens or hyena bone deposits, and cave bear dens. This new taphonomical and paleoecological interpretation of localities that have been known for decades is based on revision of available bone collections, additional field observations at existing localities, and on comparisons with recent spotted hyenas. The thousands of bones from this region, including about seven hundred Pleistocene hyena remains, are strongly fragmented by having been cracked and chewed, consistent with typical hyena activities. The localities can be subdivided chronologically as Middle and Upper Pleistocene, or taphonomically as horizontal and vertical caves and karst depressions. Horizontal and vertical caves show contrasting types of bone accumulations. Several vertical cavities were filled in the Middle Pleistocene and contain the remains of Pachycrocuta brevirostris and its prey. This is the case of the areas of Srbsko-Chlum and Koněprusy-Zlatý Kůň Hill. In the Upper Pleistocene, at least eight caves in the Bohemian Karst were used by hyenas of Crocuta crocuta spelaea as dens and prey storage, some of which were also used by cave bears for hibernating. Upper Pleistocene cave bears were scavenged postmortally by Ice Age spotted hyenas at four cave sites, where they left cracked and chewed Ursus spelaeus bones. Hyenas also stored the remains of their prey in the caves. These remains also include rests of other hyenas, which indicates cannibalism. Fecal pellets were used for marking the den sites. The Nad Kačákem Cave near Hostim is shown to have been a frequented hyena den based on the presence of many "nibbling sticks" and the remains of juvenile hyena bones. Many hyena skeletons of $C$. c. spelaea, including juveniles and adults, their coprolites, and the partly cracked bones of their stored prey, were found in vertical caves such as Srbsko-Chlum-Komín. The most spectacular finds are a nearly complete skeleton of the female steppe lion Panthera leo spelaea and an embryo of the Przewalski horse Equus ferus przewalskii. A nearly complete hyena skeleton in the Koněprusy Caves-Prošek Dome is another remarkable find. The most bone-rich localities at Koněprusy-Zlatý Kůn̆ Hill and Srbsko-Chlum Hill are located on, or close to, exposed hill tops, where hyenas had an overview of the surrounding landscape. Statistical analysis of the remains shows that the main animals preyed upon by Upper Pleistocene hyenas were Equus ferus przewalskii and Coelodonta antiquitatis. Additionally, the hyenas fed on Bison priscus, Rangifer tarandus, Cervus elaphus, Megaloceros giganteus, Equus hydruntinus, the Bohemian alpine fauna including Rupricapra rupricapra and Capra ibex, and even the carnivores Ursus spelaeus, Panthera leo spelaea, Canis lupus and possibly Gulo gulo. The very few remains of the mammoth Mammuthus primigenius seem to indicate its scarcity in the hilly Bohemian Karst. Sediments in the horizontal caves show that, after being used by cave bears or hyenas, they were inhabited by foxes or marmots, and more recently by humans, especially during the Magdalenian period and later in the Holocene. - Key words: Crocuta crocuta spelaea, Upper Pleistocene, prey deposit types, prey bone accumulations, bone taphonomy, hyena paleoecology, Bohemian Karst, Czech Republic.
\end{abstract}

DIEDRICH, C.G. \& ŽÁK, K. 2006. Prey deposits and den sites of the Upper Pleistocene hyena Crocuta crocuta spelaea (Goldfuss, 1823) in horizontal and vertical caves of the Bohemian Karst (Czech Republic). Bulletin of Geosciences 81(4), 237-276 (25 figures). Czech Geological Survey, Prague. ISSN 1214-1119. Manuscript received July 31, 2006, accepted in revised form November 6, 2006, issued December 31, 2006.

Cajus G. Diedrich, Academy of Sciences of the Czech Republic, Institute of Geology, Rozvojová 269, 16502 Praha 6-Lysolaje, Czech Republic; cdiedri@gmx.net • Karel Žák, Academy of Sciences of the Czech Republic, Institute of Geology, Rozvojová 269, 16502 Praha 6-Lysolaje, Czech Republic; zak@gli.cas.cz 


\section{Introduction}

The Bohemian Karst is located SW of Prague, approximately between Prague and Zdice. The area in which Silurian and Devonian limestones (folded and faulted into the complex Prague Synform) outcrop is about $33 \mathrm{~km}$ long and up to $8 \mathrm{~km}$ wide. There are 672 known caves with a total length of more than $21 \mathrm{~km}$ in the Bohemian Karst (Žák et al. 2005). The caves are usually small, of complex morphology, have long evolutionary histories, and are frequently filled with sediments of mostly Tertiary and Quaternary age. Details about speleogenic processes will be discussed in Žák et al. (submitted). Paleontological finds (bones, molluscs) are recorded from the sediments of 58 caves, but only several localities yielded large bone collections. About $60 \%$ of the known caves have been discovered in limestone quarries, which also contain numerous sedimentfilled karst depressions ("karst pockets"). However, only a few of the several hundred quarried-out karst depressions contained rich bone material. The small number and the richness of the bone localities shows that the frequently considered explanation of animals falling into caves, or their remains being washed down into the depressions, were not the dominant mechanisms by which these bone accumulations formed. There are numerous vertical caves with dangerous-looking entrances in the Bohemian Karst that contained no Pleistocene bones at all. Similarly, larger animals were not found to fall inside the Bohemian caves under present conditions (as happens frequently to frogs and snakes), and all modern bone accumulations inside and close to caves are a result of the activity of common foxes (Vulpes vulpes) or badgers (Meles meles). Therefore, other processes of formation for these rich Pleistocene bone accumulations must be considered.

During more than 180 years of scientific cave palaeontology within this area, initiated in 1824 by Count Kašpar Šternberk in caves near Srbsko, tens of thousands of large Pleistocene animal bones have been found, some of which have been mentioned or figured in local Czech journals and books (Woldřich 1893; Kafka 1892b, 1900, 1903, 1909; Petrbok 1938a, 1939a-c, 1940a, 1940b, 1941, 1942, 1943a, b, 1956; Zázvorka 1954; Fejfar 1956a, b, 1961a, b; Beneš 1970; Horáček 1979, 1982, 2000). None of these publications have described or interpreted the cave sites exclusively as hyena dens or prey deposit caves, though some chew marks at least on bones were mentioned (e.g., Woldřich 1893, Fejfar 1958, 1961a, Beneš 1970). Chew marks on bones from the Srbsko-Chlum-Komín locality were interpreted to indicate hyena activity by Fejfar (1958, 1961a). The possibility that this locality was a hyena den was also mentioned in the review of a book by F. Skřivánek (Kučera et al. 1981). Nevertheless, nearly all interpretations of the bone-rich caves were that the bones must have been washed into the cave (Woldřich 1893; Kafka 1903), or that living an-

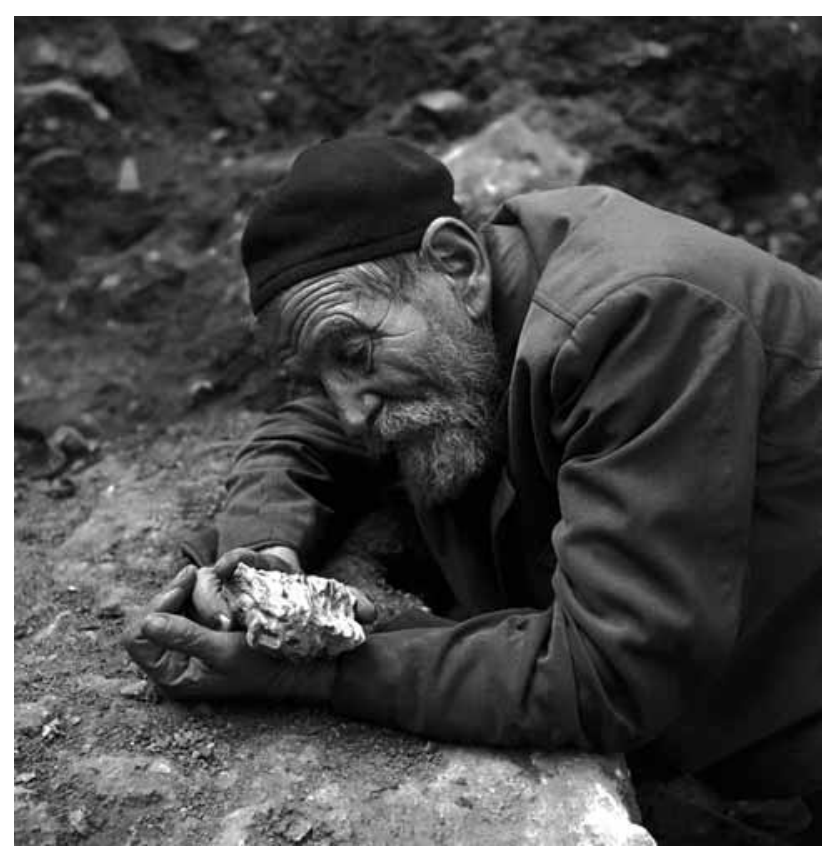

Figure 1. The most famous bone collector of the Bohemian Karst was J. Petrbok (*25 Oct $1881-\dagger 14$ Dec 1960). His large collection is housed at the National Museum in Prague, but lacks exact documentation (Photographic archive of the Czech News Agency, with permission).

imals fell into them, with the bones being gradually destroyed by solifluction and falling stones (Beneš 1970). One of the most interesting interpretations is that of J. Petrbok, a famous bone collector (Fig. 1), who believed that the giant Middle Pleistocene beaver "Trogontherium sp. cf. cuvieri Fischer", found in some remains in the caves near Srbsko, was responsible for the destruction and chewing of the bones (cf. Petrbok 1938b, 1943b). He also frequently misinterpreted scratches on bones to be of Palaeolithic human origin (Petrbok 1947, 1953, 1956; this interpretation was already corrected by Fejfar 1958).

These earlier interpretations will be revised here in the context of new studies on the bone accumulations of the Upper Pleistocene hyena Crocuta crocuta spelaea (Goldfuss) (Fosse et al. 1998, Currant 2004, Diedrich 2004b, $2006 \mathrm{~b}, \mathrm{c})$, and by actuopaleontological comparisons to the ecological behaviour of the recent African spotted hyena Crocuta crocuta crocuta Erxleben and its den and prey deposit sites ( $c f$. e.g., Scott \& Klein 1981, Avery et al. 1984, Skinner et al. 1986). For this study, we used research material from East-African hyena dens, kept in the Sutcliffe collection of the British Museum of Natural History in London, some of which is figured here. The old name "cave hyena" is revised here to "Ice Age spotted hyena". The Upper Pleistocene hyena is genetically related to the modern spotted hyena, and did not live only in caves.

The present study is complicated by two factors. First, field documentation during the earlier excavations was generally not good, with bone material from several layers 


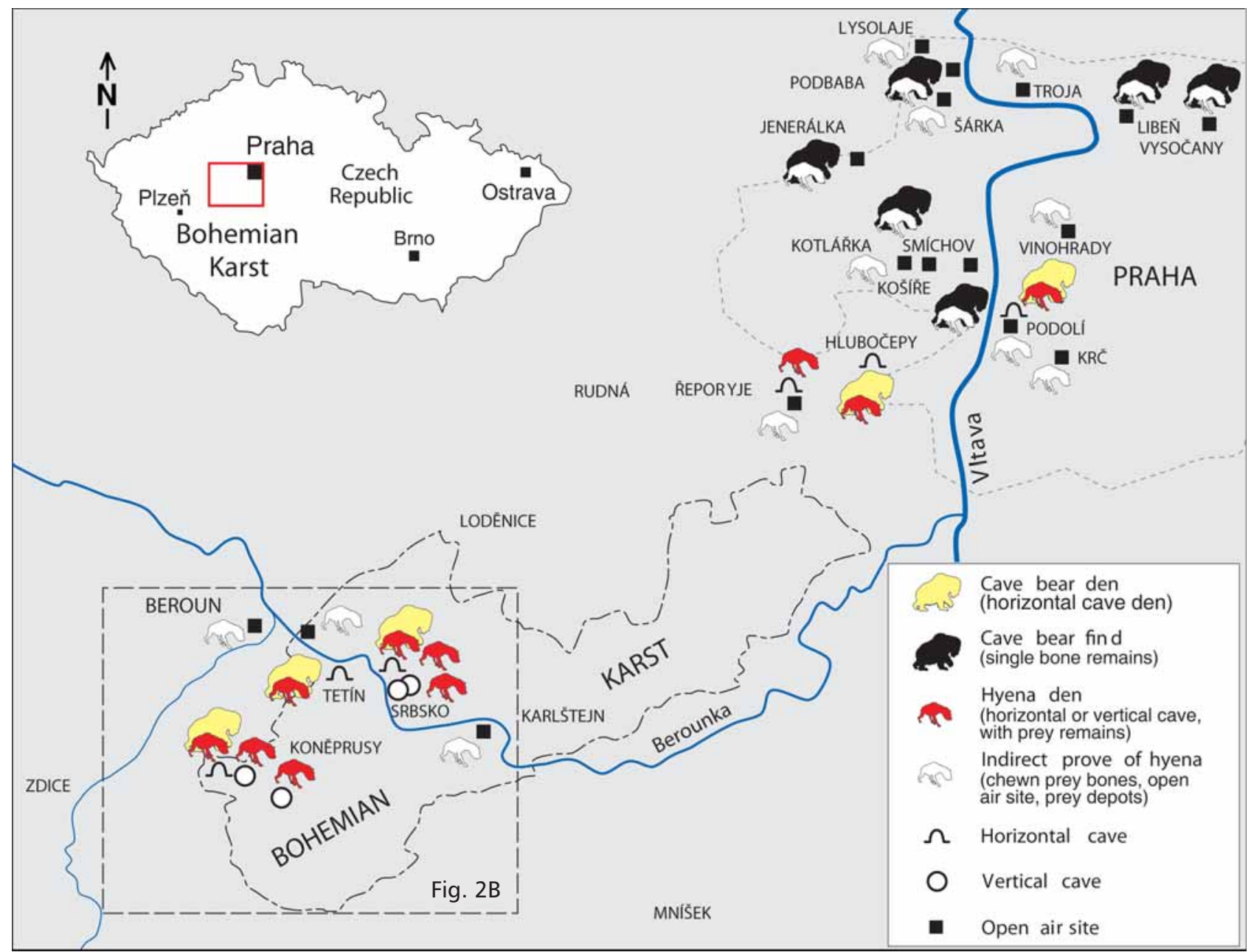

Figure 2A. Locations of the studied sites in the Bohemian Karst and Prague region. Selected bone accumulations at open air loess sites are also included (cave bear sites from Diedrich 2006a).

of different ages and origins being frequently mixed together. Secondly, the hyena sites were frequently used for dens or food storage by smaller animals, such as the arctic fox [Alopex lagopus (Linné)] and common fox [Vulpes vulpes (Linné)]. It is also unclear if the remains of the wolverine Gulo gulo (Linné) represent hyena prey, or if they also used the caves periodically to store mainly reindeer remains. Finally, marmots have also used these caves as their dens. Large mammal remains were brought into the sites only, or at least mainly, by hyenas, or perhaps later by humans during the Magdalenian (Vencl 1995, Svoboda et al. 2004). Such multiple use seems to be quite common in the horizontal caves of the Bohemian Karst.

\section{General characteristics, research history, and bone material of the cave localities}

The studied localities within the Bohemian Karst are shown in Fig. 2. Detailed maps of the two most important areas are presented in Fig. 3 (Srbsko-Chlum) and Fig. 4 (Koněprusy-Zlatý Kůň Hill).

\section{Srbsko-Chlum Hill}

All Pleistocene paleontological sites at Srbsko-Chlum occur within an abandoned limestone quarry (in operation from 1920-1961 and 1970-1974), on the southern slopes of the Chlum Hill. Sediments of nine different sites within the quarry are known to contain bone material of various periods from the Lower Pleistocene to the Upper Pleistocene. This, along with unique finds of nearly complete skeletons (see below), makes this quarry a Quaternary site of European importance.

During the period between 1938 and 1953, the quarrying exposed several sediment-filled, vertical karst cavities (Petrbok 1939a, 1942; Homola 1945) that were subsequently designated as Sluj I to VI (i.e., paleontological localities Chlum I to Chlum VI) (see Fig. 3). The positions of 
Sluj I to Sluj IV are known, and parts of Sluj II to Sluj IV still exist with relics of their sediment filling. Sluj VI was located in the eastern part of the quarry (quarried out in 1957), under which a fossiliferous sediment-filled depression has survived below the quarry bottom, recently named "Locality Chlum VIII".

The position of Sluj V is not known. It may have been the upper part of the Chlum-Komín locality. Sluj V was studied by Petrbok (1943a), who did not give its precise position. Most authors (Skřivánek 1954; Kučera 1985) locate it, based on unwritten tradition, above the Fialová Cave (see Fig. 3). Our opinion is that the occurrence of an Upper Pleistocene fossiliferous locality in this sector of the quarry, more than $50 \mathrm{~m}$ below original surface, is improbable. Petrbok (1943a) states that the upper part of Sluj V was destroyed by the quarrying, and that the sediments collapsed inside the cavity after heavy rains in May 1942. He also states that above his Sluj V is a karst cavity with Miocene sediments, which is present above Chlum-Komín, but is not currently known in the area above Fialová Cave. Kučera (1985) adds that Sluj V was located in the Kotýs Limestone, which is absent above Fialová Cave, but present at Chlum-Komín locality. The fossilization of the bones collected by Petrbok in 1942 at his Sluj V is similar to that of material from Chlum-Komín, and the (limited) faunal assemblage is also similar. These facts indicate that what was called Sluj V might be identical with the Chlum-Komín locality.

The famous Chlum-Komín site (named by Beneš 1970, also called "Locality Chlum VII" by I. Horáček, and "Poslední Dóm” by O. Fejfar) occurs at the southern rim of the quarry. Its bottom connects to Poslední Dóm (Last Dome) of the deeper Srbské Caves. The deeper parts of the cave system began to be explored in the 1940s (Homola 1945, Skřivánek 1954, Kučera 1985). Further explorations have revealed the extent of the complex cave system below the quarry bottom and below the system of Sluj I to IV, while the two most important caves, Srbské Caves and Netopýŕí Cave, were interconnected in 2003 into a one cave system with a present length of $1,230 \mathrm{~m}$ and vertical extent of about $50 \mathrm{~m}$. The vertical cavities of Sluj I to V and Chlum-Komín therefore represent higher parts of the same cave system. The last fossiliferous locality at Chlum was discovered in 2004 by the present authors as a secondary bone accumulation in the Rotunda of Netopýrí Cave, approximately $40 \mathrm{~m}$ below Sluj II and III.

Research in the Chlum area started with the excavations of J. Petrbok in the vertical cavities of Sluj I to V (Petrbok 1938a, b, 1939a, b, 1939c, 1940a, 1941, 1942, 1943a, b, 1944a, 1947, 1953, 1956). The research on Sluj VI was done between 1953 and 1957 by Skřivánek \& Ložek (1953) and by Fejfar (1961b). The localities in the quarry were also studied by O. Fejfar (Fejfar 1956a, 1958, 1961a, b, 1964) and by members of the Karst Section of the Society of the
Czech National Museum (J. Kukla, F. Prošek, A. Absolon, F. Skřivánek). During this period, the early finds from Chlum-Komín were collected and studied, mostly by O. Fejfar. In the period between 1963 and 1970 most of the studies were undertaken by J. Beneš and V. Mostecký, with members of the Speleological Club of Prague guided by V. Vojiŕr. Excavations during this period were focused mostly on Chlum-Komín (Beneš \& Kovanic 1964; Mostecký 1964, Beneš 1970). Later extensive excavations of karst depressions located close to Sluj IV were guided by I. Horáček, and were focused mostly on micromammal dating (Horáček 1979, 1982, see also Horáček \& Ložek 1988, Horáček 2000). The bottom of Chlum-Komín was cleared of modern debris by members of the Speleological Club of Prague in 2005/2006, which yielded some additional bone material. Research on the sediment filling below the former Sluj VI (i.e., locality Chlum VIII) was conducted in 2006 by I. Horáček and co-workers.

Based on their morphology, all sites at Chlum can be considered as accumulations in vertical or steeply dipping cavities, filled by sediments from above and (periodically) opened to the surface. Nevertheless, some of these cavities could have provided partial access to animals through narrow branching corridors, or along the slopes of infilling sediment.

Based on present knowledge, the oldest fossiliferous sediments are represented by the deeper part of the filling of Sluj VI (and the recently excavated locality Chlum VIII below it), where dark-rusty and dark-red coloured loams contain micromammal fauna belonging to the basal part of the Biharian, i.e., Lower Pleistocene (Fejfar 1961b, Ivan Horáček, personal communication 2006). A very rich Biharian fauna corresponding to the lowermost Middle Pleistocene, with spectacular bone breccias, is present in the sediment of Sluj IV, and to a smaller degree in Sluj II and III. Microfauna from adjacent excavations (Horáček 1979, 1982) correspond to the same period, and cover two glacial/interglacial cycles (600-700 ka BP). The dating of these localities is further supported by their relationship to river terraces (Tyráček 2001, Tyráček et al. 2004). The Sluj I assemblage collected by J. Petrbok (Petrbok 1941) was interpreted by Beneš (1970) as being slightly younger, probably representing the end of the Cromerian.

The richest site of the Chlum quarry is that of Chlum-Komín, dated generally into the Upper Pleistocene (Weichselian) as yet without radiocarbon dating (site description and fauna determination by Fejfar 1956a, 1961a, b; Mostecký 1964; and Beneš 1970). Based on the present study, the Chlum-Komín locality contained more than five partial hyena skeletons (three juveniles, one adult male, one young adult female, and one cannibalised adult) and much of their prey, including the skeletons of two lions Panthera leo spelaea, a neonate Przewalski horse Equus ferus przewalskii, and an enormous macrofauna (mainly 


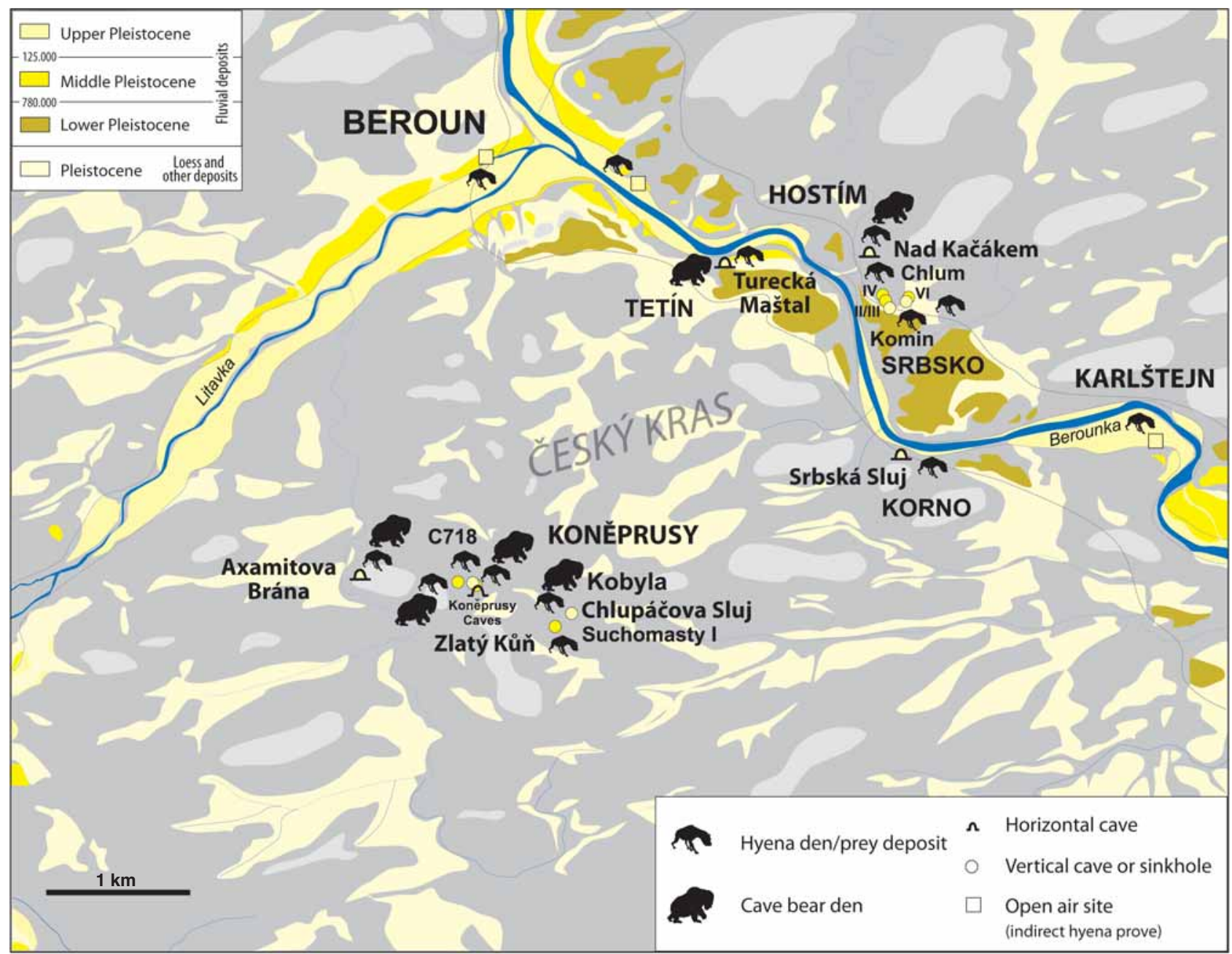

Figure 2B. Locatins of the studied sites in the Bohemian Karst. Selected bone accumulations at open air loess sites are also included (cave bear sites from Diedrich 2006a). For location see also Fig. 2A.

hyena prey) dominated by horses. Other remains at this Weichselian hyena prey deposit site include Coelodonta antiquitatis, Bison priscus, Rangifer tarandus, Rupricapra rupricapra, Capra ibex, and even Canis lupus and Gulo gulo. This site was used later by common foxes Vulpes vulpes for prey storage (mostly fish, frogs and the hare Lepus europaeus/timidus or Lagopus lagopus). Foxes and the snow owl Nyctea scandiaca left tens of thousands of micromammal bones in their excrements. Finally the Chlum-Komín site was inhabited by the marmots Marmota marmota. This vertical cave contained the largest amount of bones, all 3,569 of which are statistically analysed here for the first time. An initial sedimentological study has found a very high percentage of small hyena coprolite fragments, which is typical for strongly frequented hyena den sites. Some of the coprolites are completely preserved.

Of the same Upper Pleistocene age (no radiocarbon data yet) is a deposit of molluscan material and bone matter from the upper part (chimney) of Sluj VI (Bison priscus, Equus ferus przewalskii, R. tarandus etc.), which was incorrectly identified as "Bos primigenius" or "Mammonteus primigenius" (Skřivánek \& Ložek 1953).

\section{Koněprusy-Zlatý Kůň Hill}

Zlatý Kůň ("Golden Horse”) Hill has been strongly damaged by limestone quarries on its southern and western slope. This hill hosts the Koněprusy Caves, the largest cave system of the Bohemian Karst (length 2,050 m, vertical extent more than 70 m, Kučera et al. 1981). Partly superimposed Lower, Middle and Upper Pleistocene fossiliferous layers occur within the Koněprusy Caves in the Prošek (Main) Dome. Aside from this locality inside the caves, a detailed study of the sediment-filled karst depressions exposed in quarries on the southern and western slopes of the hill revealed further important bone material. A general 
map of the area with the positions of Pleistocene paleontological localities is shown in Fig. 4. The extent of the Císařský Quarry, with the location of karst depressions shown on this figure, corresponds to the situation in the early 1950s, and is redrawn after Kukla (1953). Zlatý Kůň Hill also hosts one older Pliocene paleontological site, and younger Holocene paleontological and archaeological sites, which are not discussed here.

The most important period of research was initiated by the discovery of the Koněprusy Caves in 1950 (for the history of the discovery, see Kovanda 2002). The collection of bone material from the surface of a sediment accumulation cone in the Prošek Dome was partly uncontrolled in the past, and bone material thus became distributed among several collections. Well defined terminology had not yet arisen at that time, so Petrbok's collections from the same dome have the labelling and inscription "Petrbokova Sluj" (which today is the name of a partly quarried section of the middle level of the Koněprusy Caves), while some other collections (such as that of O. Fejfar) are labelled as "Main Dome". The Main Dome was renamed Prošek Dome after Prošek's death in 1958. Extensive systematic excavations in the Prošek Dome were carried out shortly after the discovery of the caves (Kukla 1952; Stárka et al. 1952; Vlček 1952a).

Karst depression C718 at the rim of Císařský Quarry is an important locality that was discovered in 1952 (Fejfar 1956a). Further studies were undertaken by Fejfar in 1953. The deeper layers of the depression were studied in 1954, and during a severe winter in early 1956 when F. Prošek performed a rescue excavation of this bone-rich locality, resulting in paleontological material that became famous through the papers of Fejfar (e.g., Fejfar 1956b, and later).

More recent excavations and paleontological studies of Prošek Dome were conducted by Fejfar (1966, 1973), Lysenko (1976), Fejfar \& Heinrich (1983), Horáček (1984, 1990), Ložek (2000), Wagner (2003). The present knowledge was reviewed by Fejfar et al. (2004).

The oldest Lower Pleistocene (Lower Biharian, roughly equivalent to Chlum VI) microfauna, consisting mostly of bats, was found by Horáček (1984) below the collapsed cave roofs in the NW part of Prošek Dome, in an older excavation by Lysenko (1976). The most widespread sediments (covering most of the area of the Prošek Dome, stratigraphically above the fallen roofs) contain abundant bear bones, classified recently by Wagner (2003) as $U$. deningeri (similar to U. deningeri finds from the $\mathrm{C} 718$ site). Only a few remains of Pachycrocuta brevirostris, including its coprolites and prey remains, indicate intermittent hyena habitation. The bones from this level are yellow, impregnated by limonite, and are well fossilized. The distribution of this older layer within the cave was possibly influenced by solifluction and additional freezing, and by being trampled by cave bears (the "Mohyla" stalagmite in the middle of Prošek Dome was also badly damaged by freezing, see U-series dating of Mohyla in Žák et al. 2004a). A tongue of the same sediment layer penetrates into a southern branch of Prošek Dome called "Cave below the Lift" (Lysenko 1976). Close to this section, the $U$. deningeri layer was overlain from the SE by the Uppermost Biharian sediments at the site later called "Southern Chimney", with molluscan fauna and mammalian micro-fauna (Fejfar 1966; Horáček 1990; Ložek 2000).

The surface layer of the sediment cone in the Prošek Dome consists of a bone-rich Upper Pleistocene accumulation. This layer, with its various grey-dark brown or white Weichselian fauna, includes the remains of a hyena (one skeleton, Fig. 5), abundant Przewalski horses E. ferus przewaskii, and the woolly rhinoceros $C$. antiquitatis. Many strongly chewed long bones were found from the latter, including a nearly complete and partly chewed top skull with lower jaw. Additionally, numerous macromammals such as Megaloceros giganteus, Cervus elaphus, Equus hydruntinus, $R$. tarandus, $R$. rupricapra, C. ibex and U. spelaeus or $C$. lupus have been found there. Some complete, articulated skeletons, probably Holocene in age, were also found on the surface of the sediment accumulation cone, such as the skeleton of a wolf (see photo in Mach 1951). The largest number of hyena coprolites (about 50) is known from this cave. The bones of cannibalised hyenas are only of older adults. No material from juveniles is known from this cave, which indicates that it was a $C$. $c$. spelaea prey deposit site. The find of the remains of a scavenged steppe bison Bison priscus, including a completely cracked and chewed top skull, is consistent with this type of cave. An articulated limb, which is possibly from the individual collected by Petrbok, was spread throughout the collections of the National Museum in Prague (NMP) and the Museum of Bohemian Karst in Beroun (MBKB). A total of 711 Upper Pleistocene bones from this cave were used in our analysis, all of which are stored in both of the aforementioned collections. A cranium and a few postcranial bones of a 30-40 year old Magdalenian woman were also found in the surface layer of this site (Vlček 1952a, 1957; Kuželka 1997; Svoboda 2000). Some parts of the skull show evi-

Figure 3. Cave map of the Srbsko-Chlum localities. Map sources: Chlum Quarry map from Geoindustria mapping in 1970s, corrected and supplemented by the mapping of GGS Hořovice in 2004; Fialová Cave from Kolčava (2005); Srbské Caves-Netopýří Caves based on an unpublished map of the Speleological Club of Prague, 1991-2005 mapping, by L. Vlk, C. Piskač, P. Čáslavský, L. Bláha et al. Position of Sluj I to IV is approximate. Position of Sluj VI is from Skřivánek (1954). 


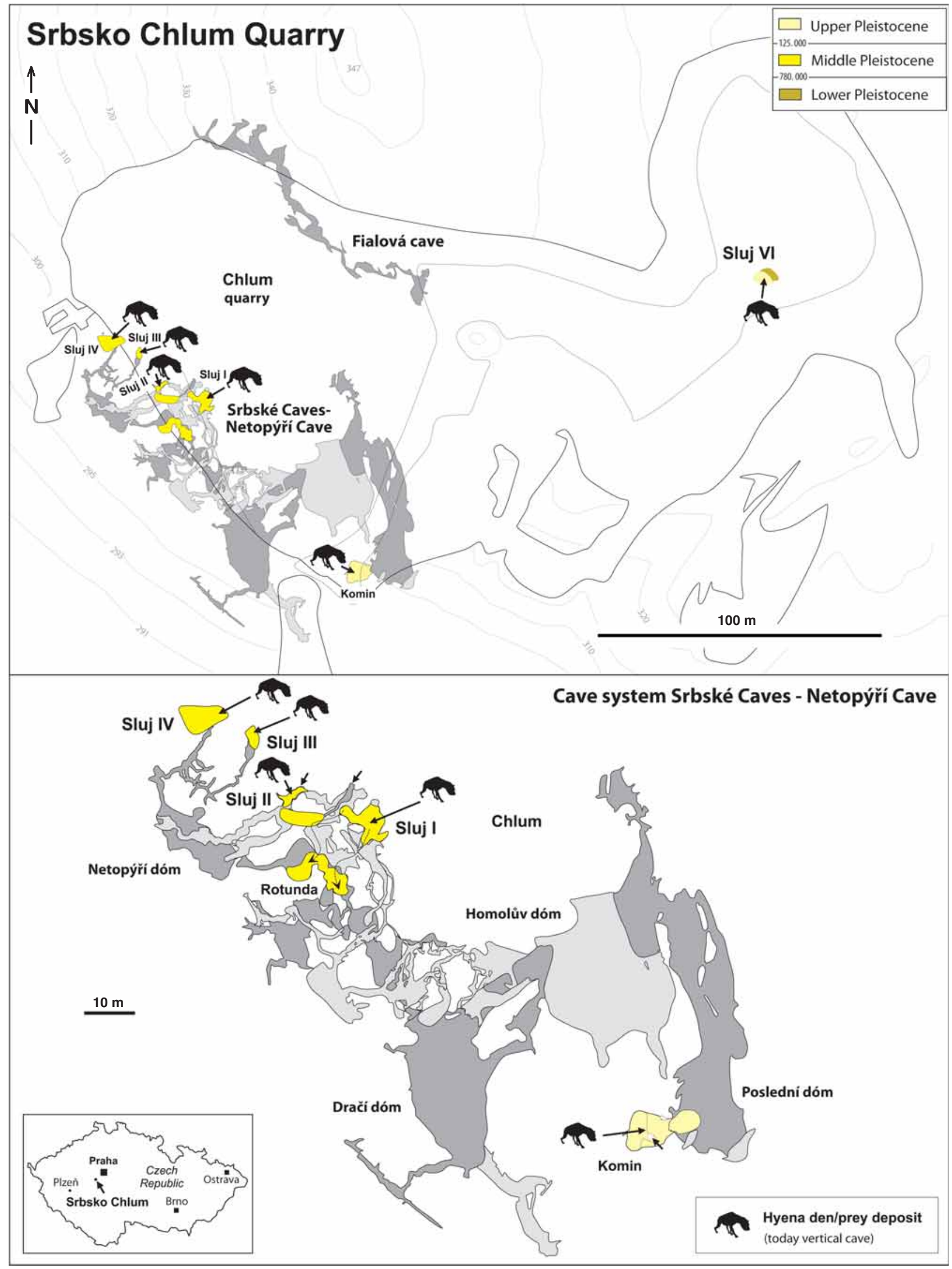


dence of chewing, interpreted by Svoboda et al. (2003) as indicating a hyena or a wolf. The human bones were ${ }^{14} \mathrm{C}$ dated (AMS ${ }^{14} \mathrm{C}$ age of $12,870 \pm 70$ years, Laboratory Groningen GrN-13696) by Svoboda et al. (2002, 2003). Since the hyena became extinct in Central Europe around 24,000 BP, wolves were probably responsible for the chewing on human bones. A recently rediscovered human humerus from the collection of J. Petrbok probably belongs to the same skeleton.

The fossiliferous Middle and Upper Pleistocene sediment filling of Prošek Dome therefore originated mostly by the transport of sediments through two periodically accessible openings located close to each other: the Southern Chimney and Lift Chimney. The taphonomy of the Middle Pleistocene layer containing $U$. deningeri is only partly discussed here, as the present article focuses mostly on the taphonomy of Upper Pleistocene layer with Crocuta crocuta spelaea.

Apart from the Koněprusy Caves, the taphonomy of the Middle Pleistocene (Upper Biharian) bone-rich fill of pocket C718 (Fejfar 1956a, 1956b, 1961b) is also discussed. Pocket C718 is just west of the upper end of Lift Chimney, and is filled by bone remains from a warm-climate Middle Pleistocene fauna including elephants, horses, cervids, bovids, felids or even apes, and hyenas. This material should be restudied in the future. The pocket contained faunal remains in several layers, covering an interglacial-glacial-interglacial cycle, with probable hyena habitation during some periods.

\section{Koněprusy-Kobyla Hill}

Kobyla Hill, located between Koněprusy and Suchomasty, has long been quarried, with use of the red Suchomasty limestone of Červený Quarry dating back possibly to the Middle Ages (written documentation of quarry operations dates from 1840) and the Kobyla Quarry to the second half of the nineteenth century. The first find of Pleistocene bones in Červený Quarry occurred in a horizontal cave called "V Červeném lomu" (later called Suchomasty I, Kafka 1892b) sometime after 1885. Schubert (1900) described the Upper Pleistocene fauna ("Hyaena spelea, Cervus capreolus, Equus caballus fossilis, Rhinoceros sp., and Tetrao urgallus?") from a currently quarried-out cave in the Kobyla Quarry, which was probably part of the Chlupáčova-Zlomená Sluj cave system. Modern research on Chlupáčova Sluj started in 1950, when I. Chlupáč, based on the information from quarry workers, collected bones on the slope of Kobyla Quarry and gave them to J. Petrbok, who then began the first excavations there (Petrbok 1950a, 1952; see also Kovanda 2002). Further excavations (mostly from 1950-1963, and 1968-1971) and research yielded an Eemian and Weichselian fauna (dated by the macrofau- nal assemblages only) and Palaeolithic artefacts, which constitute some of the oldest human traces of the Bohemian Karst (Zázvorka 1954; Petrbok 1954, 1956; Mostecký 1961, 1963, 1966, 1969; Kovanda 1973).

At the beginning of his research, J. Petrbok considered the section to be disturbed and the layers mixed, and he therefore collected all of the bone material together. This mixing of Eemian and Weichselian fauna and the damage to the material present problems for the analysis of this locality. Bones that were broken and show hyena chew marks, in addition to hyena bone remains and coprolites, indicate a hyena prey deposit. Abundant "fireplaces" (charcoal accumulations) and Palaeolithic artefacts also indicate the presence of humans. Because of the faunal mixing, this is the only large site for which faunal assemblage proportions were not analysed in the present study. Nonetheless, some significant remains from this site include that of a juvenile steppe lion, and of a juvenile rhino, the ages of which are as yet unclear. At least 2,500 bones were collected here, mainly by J. Petrbok, which are still mostly unprepared and fragmented.

\section{Tmaň-Axamitova Brána Cave at Kotýz}

This site is located at the western rim of the Kotýz (also Kotýs, Kotys) Plateau, which forms the western part of the Zlatý Kůň-Kotýz Range. It is another site with a complex sedimentation history, repeated prehistoric human activity, and numerous badly documented excavations (see a review of the voluminous literature and research history in Matoušek et al. 1985). The site is characterised by a horizontal passage below a wide rock arch with a vertical, open roof cavity.

Its stratigraphical record has been almost completely destroyed. Discussions as to whether or not the roof of the main cavity collapsed (and if so, when) have not resulted in a generally accepted conclusion. The vertical cavity was probably artificially filled during the Middle Ages, possibly by material from prehistoric and early historic fortifications above the cave. The site and its bone material are therefore not suitable for detailed research, since bone accumulations resulting from animal activity are intermixed with those from Middle Palaeolithic and Magdalenian humans. The former assumption on the den of the cave bear U. spelaeus in this cave was not conclusively proved (U. spelaeus is present as fragmented bone material, $c f$. Beneš in Matoušek et al. 1985). Carcasses of these animals were scavenged by the hyenas $C$. crocuta spelaea, which left many cracked and chewed bones. Altogether $221 \mathrm{Up}$ per Pleistocene bones (dated by the macrofaunal assemblage), including chewed $C$. antiquitatis, E. ferus przewalskii, E. hydruntinus, C. elaphus, R. tarandus, Capra ibex, and C. lupus were studied from the Axamitova 


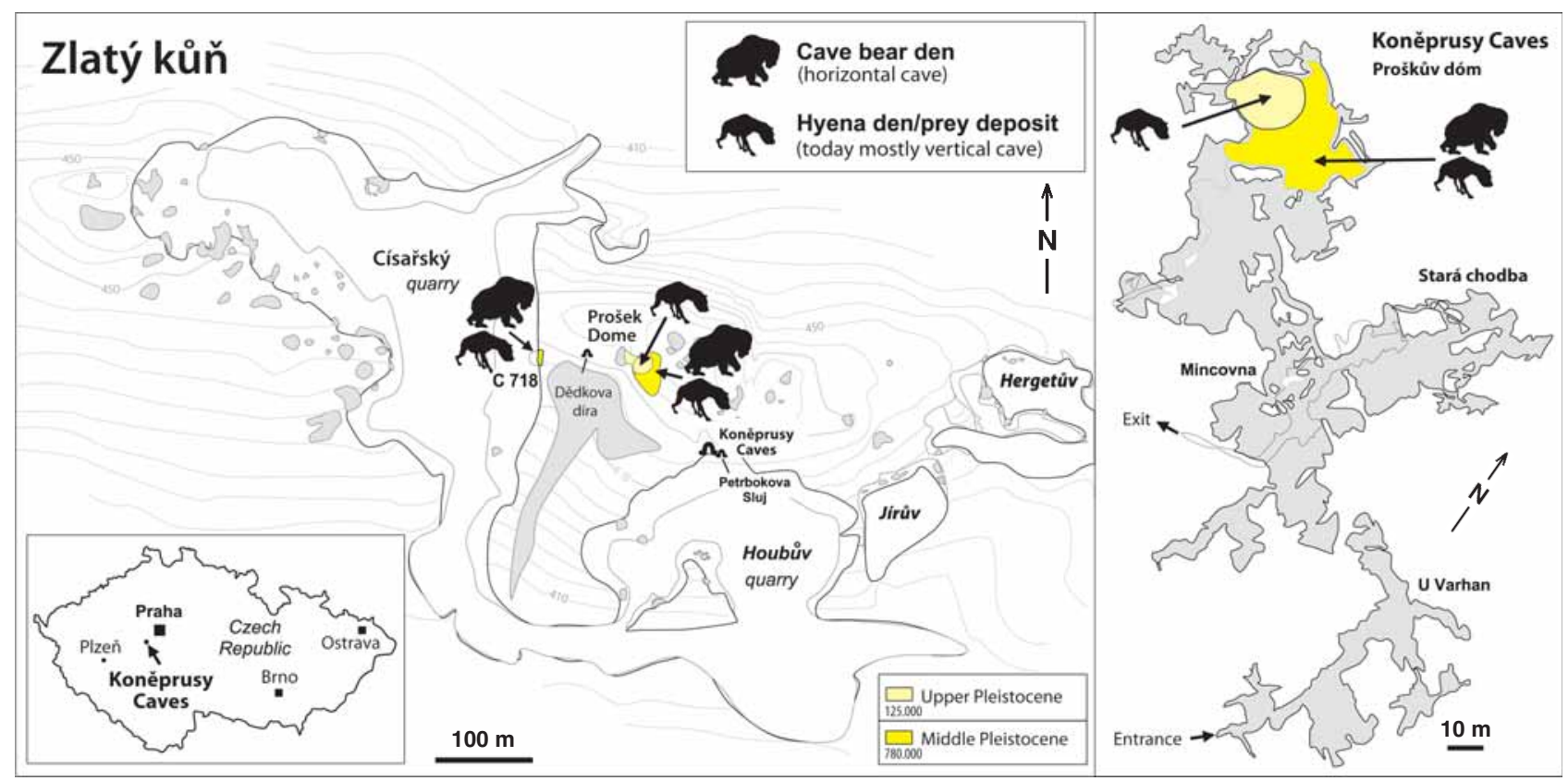

Figure 4. Positions of the vertical cave and hyena prey deposit and den sites at Zlatý Kůn̆ (Golden Horse) Hill. Graphics: Diedrich. The quarry map shows the position of the quarry rims in the 1950s, and is from Kukla (1953). The map of the Koněprusy Caves is from Kučera et al. (1981). The grey marked depressions are filled with Tertiary and Pleistocene deposits.

Brána Cave locality for the present analyses. Bones from Holocene archaeological layers are not evaluated here. No hyena coprolite material was collected or is yet known from this locality, but a few mainly juvenile hyena teeth and jaw remains are present, which are typical of hyena dens.

\section{Nad Kačákem Cave near Hostim}

This cave opens by a large portal in the steep slopes of the Kačák (Loděnice) Valley south of Hostim. The section of the cave located close to the entrance, important for archaeological and paleontological finds, is horizontal or slightly inclined inside the rock massif. The deep and extensive sections of the cave, mostly discovered in 1984 and 2000, are morphologically complex, following a system of faults.

Research in this cave was first initiated by J. Kafka in 1900. Systematic excavations, during which practically all sediments containing archaeological materials (and some Upper Pleistocene layers below) were excavated, were undertaken from 1930 to 1935 by J. Petrbok, and in 1940 by J. Petrbok and F. Prošek. In 1942 the German archaeologist L.F. Zotz, who had a well founded disbelief in the quality of Petrbok's field documentation, excavated the "control pillar" left by Petrbok for future reference. Following this period of research the cave was $28 \mathrm{~m}$ long, and practically all of the archaeological horizons (Middle and Late Paleolithic, Neolithic, Eneolithic, Bronze Age,
Middle Ages) had been removed (see Stehlík 1935, Petrbok 1940b, 1944b, 1956, Zotz 1942, Prošek 1947, Sklenár̆ 1991). New excavations by the Speleological Club of Prague began in the 1980s. No care was taken of the bone content of the Pleistocene sediments during this work. I. Chlupáč later found a part of hyena skull on a waste dump, and publicly criticised the speleologists several times. Only a small relict of fossiliferous sediments (with surface area about $5 \times 2 \mathrm{~m}$ ) survives in the cave today.

A total of 423 bones of $C$. antiquitatis, E. ferus przewalskii, C. elaphus, $R$. tarandus, Capra ibex, $R$. rupricapra, U. spelaeus, C. c. spelaea and C. lupus from this cave indicate an Upper Pleistocene age, and were used in the present study. The bone material labelled by J. Petrbok mostly as from the "archaeological Magdalenian" horizons is clearly from the older horizons of animal den periods. Nearly all of the macromammal bones are strongly chewed and cracked. The degree of fragmentation is very high. However, the large number of preserved "nibbling sticks" (see definition in Diedrich 2005c) is a very unique find from this site. Many juvenile hyena remains and fragmented bones of cannibalised C. c. spelaea are known from this site. Hyena coprolites have not been reported.

\section{Turská Maštal Cave at Tetín}

This locality is one of several that were completely (or almost completely) destroyed by quarrying, and from which 
only published information and some bone specimens are available for study. Finds of bones that are probably from this locality are mentioned in Hájek's "Bohemian Chronicle" from 1541 (Hájek z Libočan 1541). The caves, originally extensive and morphologically complex, were first described in the second half of the nineteenth century. The earliest excavations were done in 1879 by J. Richlý and V. Vojáček. The rock promontory, with a medieval castle on top and the cave below, was mapped by B. Jelínek in 1883. Before most of the cave was quarried out, the locality was studied by J. Kafka in 1890 and J.L. Píč in 1891. The last excavations were conducted between 1930 and 1933 by Petrbok (see Píč 1891; Kafka 1893; Woldřich 1893; Petrbok 1920, 1932, 1950b). The cliff face above the cave entrance partly collapsed in June 1956, and was later modified by several blasts. The unstable cliff face was injected with concrete in 1972-1975. The cave was used by humans in two periods of the Middle Paleolithic, and possibly in the Late Upper Palaeolithic (Magdalenian), and again in the Neolithic and Bronze Ages. J. Petrbok found a bear skull in the cave and interpreted its position as resulting from a "ceremonious burial" by humans. Unfortunately, neither photographs of this find nor the skull itself are available today.

At this locality it was necessary to separate the Pleistocene bones from the Holocene bones brought by humans, the distinction between which is obvious from the manner of bone preservation and the different Pleistocene and Holocene macrofauna. The cave bear $U$. spelaeus also seems to have hibernated in this cave, which would mean that it represents one of the few cave bear dens in the Bohemian Karst. This was clearly a multi-use cave throughout different periods. Altogether 357 Upper Pleistocene bones of C. antiquitatis, B. priscus, E. ferus przewalskii, C. elaphus, $R$. tarandus, C. ibex, P. leo spelaea, U. spelaeus, C. c. spelaea and $C$. lupus from this locality were studied for the present article. Very few hyena coprolites are preserved, although a large percentage of destroyed pellet material in the matrix of an old sediment sample confirms that it was a frequented hyena den. Many juvenile C. c. spelaea remains, mainly tooth and jaw material, further support this conclusion.

\section{Hlubočepy-Svatoprokopská Cave}

This locality, which was once famous as a place of pilgrimage and a hermitage, was destroyed by the Prokopský Quarry after 1887. The cave was located in Prokopské Valley near Prague. Part of the cave was open to the public in the second half of the nineteenth century. The cave was about $120 \mathrm{~m}$ long, generally horizontal or slightly inclined, with some chimneys (see map and longitudinal profile by K. Ebner \& F. Špatný from 1845, published e.g., by Vlček 1952b). A voluminous list of references, including imagi- native literature, relates to this locality (e.g., Kořenský 1883a, b, 1888, 1890; Woldřich 1889, 1919; Kafka 1890, 1892a; Babor 1904; Skutil 1952a, 1953; Vlček 1952b-d; Cílek 1993, 1995).

The most abundant bone material was collected in 1887 (Kořenský 1888). It was sound in a narrow cavity below the cave bottom, cemented by cave sinter into a bone breccia. The faunal remains recovered from the bone breccia include the following typical Upper Pleistocene (Weichselian) species (after Kořenský 1988; Kafka 1892a; Vlček 1952c): "Elephas primigenius (= M. primigenius), Atelodus merckii (=C. antiquitatis), Bos? priscus? (= Bison priscus), Capra cf. cenomantus $(=C$. ibex), Equus caballus fossilis (= E. ferus przewalskii), Equus caballus fossilis minor (= E. hydruntinus), Rangifer tarandus, Ursus spelaeus, Crocuta (Hyaena) spelaea (= C. c. spelaea)". The hyena remains are represented only by teeth. Kafka (1892) describes the following species from the Holocene ash-rich layer: "Mustela martens sp., Foetorius (Putorius) sp., Sus scropha, Lepus timidus, Sciurus vulgaris, Microtus (Arvicola) arvalis, and Microtus (Arvicola) amphibius, Cricetus frumentarius, Mus sp., Marmota (Arctomys) bobac." These micromammal and other faunal names have been subjected to later revision, and are for the most part no longer valid.

The locality is important for finds of the Pleistocene fauna and the lower jaw of a human with an unclear taphonomy. Discussions about the Pleistocene or Holocene age of the human bone (Vlček 1952b-d; Skutil 1952a, 1953) were resolved by direct $\mathrm{AMS}{ }^{14} \mathrm{C}$ dating (5.0-5.7 ka BP and $1.8 \mathrm{ka}$ BP uncalibrated, Svoboda et al. 2004). The cave was clearly used by humans during the Neolithic and Bronze Ages (Skutil 1952a).

Materials including hyena and prey remains are preserved in the collections of the National Museum in Prague. A total of 221 Upper Pleistocene bones from this cave were used in the present analysis.

\section{Řeporyje-Kalvárie Cave}

This small, horizontal, $16 \mathrm{~m}$ long cave with a vertical chimney (see section and description in Kafka 1903) was discovered in a quarry between Řeporyje and Holyně in 1893 , and was studied in the same year by J. Kafka. The main Pleistocene bone accumulation was located in the back of the cave, behind the chimney, in a 60 to $70 \mathrm{~cm}$ thick layer of reddish clay. The remains include Crocuta spelaea (=C. c. spelaea), Ursus spelaeus, Cervus sp. (= C. elaphus, M. giganteus), Bos sp. (= B. primigenius), and Capra sp. (=C. ibex). The bones show carnivore chewing marks, which were mentioned by Kafka (1900). A few hyena remains from this layer, including an incomplete skull, lower jaws and postcranial bones are preserved in the collections of the National Museum in Prague. Above this fossilife- 


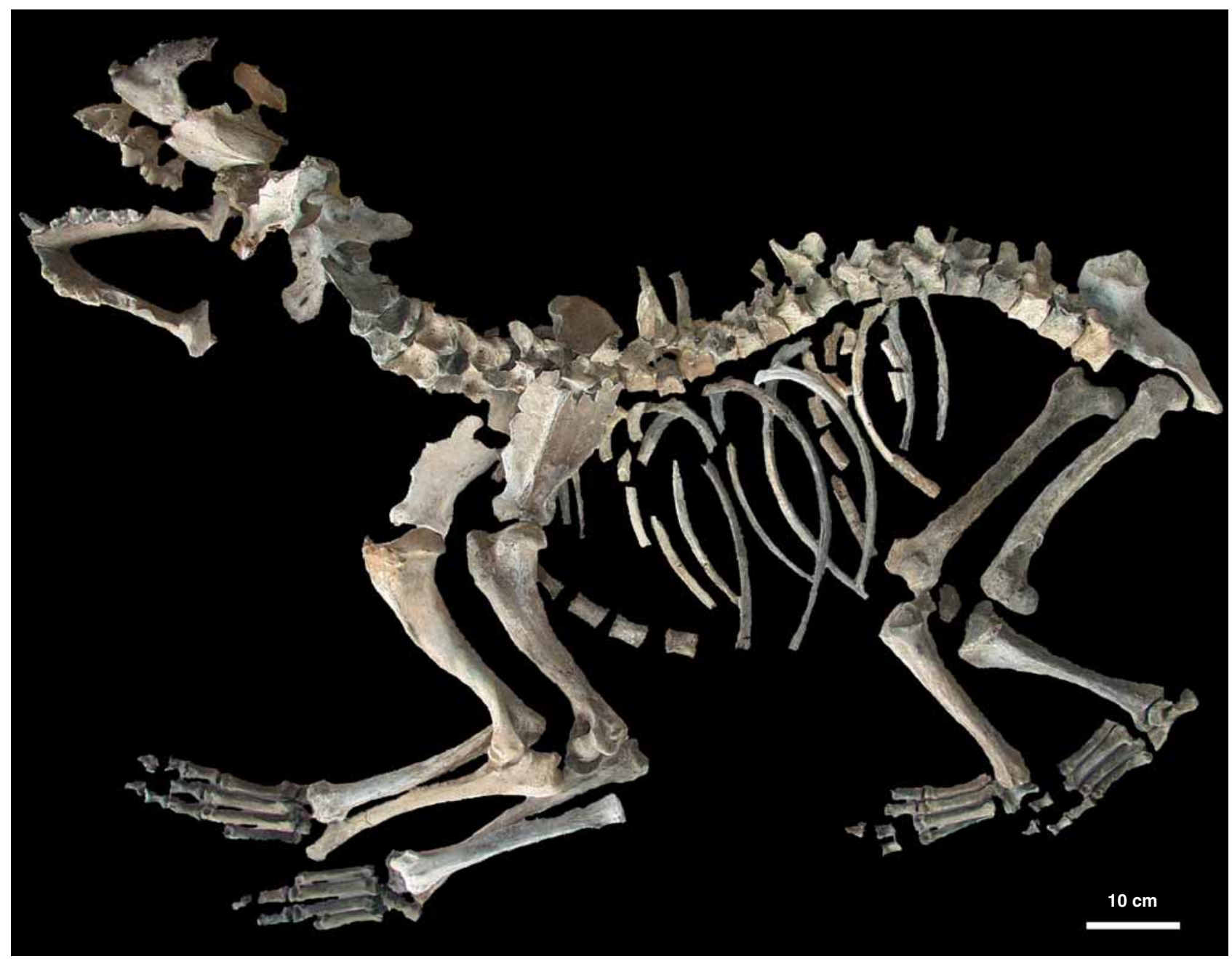

Figure 5. A nearly complete skeleton of a 15-20 year old male Crocuta crocuta spelaea (Goldfuss, 1823) individual from Koněprusy Cave-Prošek Dome (NMP No. Ra 2434). It is the most complete articulated skeleton of that species from Europe.

rous zone there was a layer of limestone debris, which was overlain by a $\sim 1 \mathrm{~m}$ thick layer of dark brown loam, which contained a Holocene macro- and microfauna including unidentified birds (see Kafka 1900). These layers were overlain by about 20 to $30 \mathrm{~cm}$ of bat guano. The cave was destroyed by quarry operations. Only 40 identifiable Upper Pleistocene macrobones are discussed here.

\section{Praha-Podolí-Dvorecká Cave}

This cave was located in the NE part of the limestone quarry in Praha-Podolí (today Praha-Podolí swimming pool), and was well-known in the nineteenth century. It was described under several names, but was most frequently called "Dvorecká Cave". Most of the cave was destroyed by quarrying in 1874 and later (Frič 1875, 1876, Kořenský 1876, Kafka 1909, Skutil 1952b). Only a few $U$. spelaeus, $C$. antiquitatis and $B$. priscus remains, inclu- ding the top skull of a cave bear, were found. A statistical analysis was not possible with the sporadic bone material from this site.

Several other cave localities in the Bohemian Karst also contained bone material (including Srbská Sluj Cave = Ivanova Cave in the Tomáškův Quarry near Korno, Liščí díry Cave and Radvanská Cave at Javorka near Karlštejn). Unfortunately, no Pleistocene bones of large mammals from these localities have survived in the known collections. Some of these sites, such as Srbská Sluj Cave, are clearly without hyena influence. Srbská Sluj Cave contains an unusual faunal assemblage, which seems to be of Upper Pleistocene age. The predominant of Lutra lutra and abundant Canis lupus, Equus hydruntinus and Cervus elaphus remains are of unclear taphonomy. This cavity was possibly a Lutra den, and will be restudied separately. None of these localities are evaluated here in detail. Localities that are either exclusively of pre-Quaternary or of Holocene age are also not discussed here. 


\section{Material and methods}

The studied Pleistocene bone material is housed in the main collection of the National Museum in Prague (abbreviated as NMP). Another smaller collection is stored in the Museum of the Bohemian Karst in Beroun (abbreviated as MBKB). More than 15,000 bones from the Middle to Upper Pleistocene localities of the Bohemian Karst were evaluated during the reorganization of the collections of the NMP. For this detailed study 5,321 Upper Pleistocene bones were selected for faunal analysis. Additionally, about 60 coprolites were identified in the collection, which constitute important evidence for the identification of hyena den sites.

Traces of human activity on the Pleistocene bones, such as cut or hit marks, or evidence of burning, were not recognized within the material considered in the present study.

The estimation of the minimum number of individuals (MNI) and number of identified specimens (NISP, the bone number of each species) was only possible for the hyena remains. Detailed analyses of the MNI and NISP will be possible in future studies, when many of the broken bones will have been restored, and new bone material from further field work will be available for statistical analysis. There are significant problems in using old collections for modern statistical analysis. Therefore only the percentages of identified bones and identified bone fragments are used in the faunal statistics.

Many of the significant bones of these large collections had not been properly and completely identified. Most of this material was collected throughout the twentieth century by J. Petrbok (Fig. 1), F. Prošek, O. Fejfar, J. Beneš, and others, frequently without modern documentation or excavation techniques. These two museum collections were used for an initial overview and revision of the bonerich caves. Thousands of mainly Upper Pleistocene bones from the NMP collection were stored in boxes labelled as "fragmentary". Their fragmented condition is the result of improper excavating techniques and of hyena activities. Many of the bones in these collections lack data about the exact positions in which they were found within the cave sediments, as modern bone distribution mapping techniques were not used. In most cases the stratigraphical information was coarsely given in historical descriptions and "sections" (e.g., Kafka 1903; Petrbok 1956). At some localities, the bone-rich horizons are still preserved and were restudied in situ.

For the reorganization and management of the Bohemian Karst bone collection at the NMP, it was necessary to separate Holocene from Pleistocene bones. In caves with multiple layers, it is sometimes difficult to separate bones from Upper Pleistocene hyena and cave bear dens from Upper Paleolithic deposits, such as in Axamitova Brána Cave, Turská Maštal Cave, Nad Kačákem Cave, and oth- ers. Bones from the Holocene layers (Neolithic, Bronze Age, Iron Age, etc.) are clearly distinguishable from Pleistocene ones. Fortunately, the bones could be separated in most cases by their distinct manner of preservation (mineral impregnations, presence or absence of chewing marks, etc.), and by species identification (see also Klein \& CruzUribe 1984; Cruz-Uribe 1991; Stiner 1991, 1994). The main difficulties of bone separation involve caves that contain archaeological horizons, such as Turská Maštal Cave or Nad Kačákem Cave. Here the Upper Pleistocene bones, which have no cutting or other anthropogenic marks, seem to have been found mainly below the archaeological horizons ( $c f$. Woldrrich 1893; Kafka 1903). Bones showing signs of chewing and cracking that typically indicate hyena den sites enabled the distinction from younger anthropogenic material imported by humans. Despite the possibility of mix-ups, which might have occurred in the Nad Kačákem Cave, cave bear, hyena and prey bones were distinguishable in most cases.

The manner of bone preservation and the degree of calcium carbonate and manganese or limonite impregnation are often helpful in identifying bones from different horizons at a single locality. At some localities the bones are preserved in a unique way and can be separated easily from those of other localities and/or layers.

Middle and Upper Pleistocene mixed bones from single localities, such as Koněprusy Caves-Prošek Dome, were distinguishable in most cases. The bones from the lower cave bear den horizon (Middle Pleistocene) in the Koněprusy Caves-Prošek Dome, are white to orange in colour and are impregnated by limonite. They also show a higher degree of fossilisation, and were often found cemented in sinter. In contrast, the Upper Pleistocene bones of the same locality, such as the hyena skeleton, are white to grey-brownish in colour and much less fossilised (Fig. 5). At Koněprusy-Chlupáčova Sluj Cave, the bones are from the Eemian to Weichselian periods and contain mineral impregnations of manganese and limonite, and are orange or dark brown in colour. This strong fossilisation resulted in a pronounced fragility that caused the material to be strongly fragmented during the digs of J. Petrbok and others. The Upper Pleistocene bones from the Srbsko-Chlum-Komín site are preserved in a unique way. They are nearly non-fossilised, and large bones are generally slightly grey-yellowish in colour (sometimes appearing dark-grey to dark brown under field conditions). Middle Pleistocene bones from the Srbsko-Chlum-Sluj I site are nearly completely white and strongly fossilised. The Middle Pleistocene bones from Srbsko-Chlum-Sluj IV are of a different colour, but are well fossilised and impregnated with minerals. Upper Pleistocene bones from Nad Kačákem Cave, Axamitova Brána Cave or Turská Maštal Cave, Hlubočepy-Svatoprokopská Cave and Reporyje-Kalvárie Cave have different colours, but are generally less fossilised. 


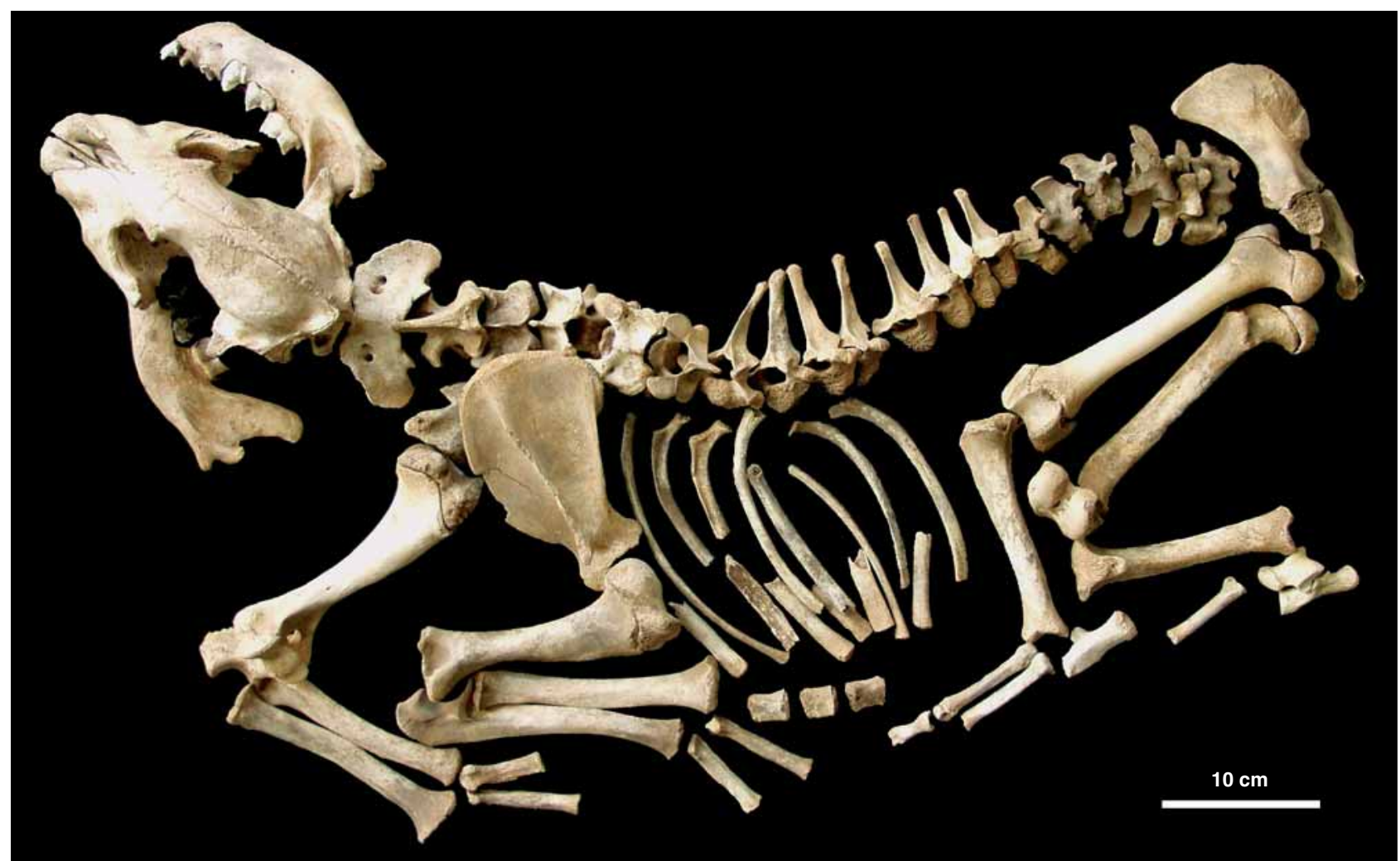

Figure 6. An incomplete skeleton of juvenile hyena Crocuta crocuta spelaea (Goldfuss, 1823) composed from the bones of different individuals from Srbsko-Chlum-Komín (NMP, each bone has its own number). At this age, the last milk teeth are still in the upper jaws and all bone joints are unfused.

The new management of the bone collections at the NMP has enabled some skeletal remains to finally be identified, organised, repaired, and prepared, such as the skeletons of a hyena (Fig. 5) and a steppe lion (see below, Fig. 12). The $C$. c. spelaea skeleton from Koněprusy Caves-Prošek Dome was spread throughout many boxes, for which three old and synonymous locality names were given by different collectors. The non-uniform labelling, collecting and storage of the skeletal material in various collections and boxes made it impossible for earlier workers to identify the skeletons. A similar situation occurred with the material from the Srbsko-Chlum-Komín locality, from which a nearly complete female $P$. leo spelaea skeleton can now be arranged. These bones were not marked as belonging to one individual, and many of them had fresh fractures as a result of unprofessional excavation work. The skeleton is incomplete: the shoulder blades were nearly missing, and only the proximal part of the right scapula was catalogued. After the reorganisation of the Chlum-Komín material, many pieces could finally be matched. For example, the smashed pelvis was fitted together in five pieces. All of the ribs, which were broken into many pieces, had been mixed with those of other macromammals. This rib cage is now the most complete known for European steppe lions, though some pieces are still missing. The left scapula was assembled from
26 pieces. Finally, the present authors discovered one scapula fragment, two rib fragments, and one upper tooth from this lion in dump material that was removed from the locality in 2005 by the Speleological Club of Prague, resulting in one of the most complete Upper Pleistocene steppe lion skeletons in the world.

These two skeletons are two positive results from the many broken and scattered bone fragments from old collections. For the statistical study (discussed below, Fig. 24) it was important to fit the bones together when possible, and to count them only once. Many of the modern-broken bones from the Srbsko-Chlum-Komín sites and Koněprusy Caves-Prošek Dome could be fitted together. The statistics given below are bone number statistics (not animal individual statistics), based on the available material.

Our C. c. spelaea bone material was compared mainly with that from the Perick Caves in Germany, which is spread throughout many museums (such as the British Museum of Natural History in London, the Staatliche Naturhistorische Sammlungen in Dresden, and the Naturkundemuseum in Bielefeld). We also compared our material to that from recent African (Tanzania, Kenya) hyena caves and open-air dens, and bones of $C$. c. crocuta Erxleben from the Sutcliffe collection of the British Museum of Natural History in London (abbreviation $=$ BMNHL). 


\section{Results and discussion}

\section{Mechanisms of bone accumulation in horizontal and vertical caves}

The studied localities with finds of bones of large Pleistocene mammals of the Bohemian Karst can be classified either chronologically (as Middle and Upper Pleistocene), or morphologically (as horizontal caves and vertical caves, the latter including karst depressions). The morphology of the sites predetermines their mechanisms of bone accumulation, i.e. their taphonomy.

Vertical caves of the Bohemian Karst mostly originated in the pre-Quaternary and/or Lower Pleistocene times, as parts of the complex cave systems formed by the slow corrosion and dissolution of the rock, usually below the water level. In the Middle and Upper Pleistocene they could have been opened by roof collapses (assisted by periodic permafrost conditions) or by seeping waters of the vadose zone. Sediment-filled karst depressions (karst pockets, which are very frequent in the entire area) mostly originated in preQuaternary times by corrosion from the surface, below a sedimentary infill. Therefore, most of these depressions in the Bohemian Karst are not typical sinkholes common to karst terrains. Nevertheless, in both cases sediments within the depressions were periodically wet and more plastic than the surrounding karst surface, and therefore constituted sites suitable for hyena prey deposition. The downward movement of the sediment could gradually transport the bone contents deeper into the cave systems. The Chlum I to IV (Middle Pleistocene) localities and pocket $\mathrm{C} 718$ are places at which this probably occurred. In some cases the sediment fell or was washed into larger, deeper chambers or domes in the caves. An example of this occurs in the Chlum I to Chlum IV sites, where a secondary bone-rich accumulation was recently found by the present authors in the Netopýř́ Cave (Rotunda section), located $40 \mathrm{~m}$ below the surface and about $25 \mathrm{~m}$ below the bottom of Sluj I to Sluj III (Fig. 3). Here, over a hundred thousand of years, solifluction has caused the complete disarticulation of what were possibly originally articulated body parts of hyena prey remains.

In the Upper Pleistocene it seems that the bone-rich sediment of the young Chlum-Komín site was not moved downwards, as suggested by the presence of articulated skeletal remains. Hyenas could probably climb into the caves, using either a narrow branching section of the cave or inclined slopes of the sediment infill. The former presence of hyenas in the cave is indicated by abundant fecal pellets (see below). The Koněprusy-Chlupáčova Sluj Cave seems to be another Upper Pleistocene locality of the same type. It has not yet been possible to distinguish hyena prey deposits from dens at some of these sites. At Koněprusy-Zlatý Kůn̆, the hilltop with a karst depression connected to the Prošek Dome is interpreted as a prey deposit (see Fig. 4 for the location, and Fig. 7 for a model of formation). Here, the hyenas had access into the cave and went down to their food storage through the chimneys, which were not completely vertical. Prey remains could also have been stored at a later time in a karst depression above Prošek Dome, and could have subsequently fallen further into the cave, though cannot be proven without further excavations.

The history of the bone accumulations is of considerable interest. The Srbsko and Koněprusy areas must have been repeatedly used during hundreds of thousands of years by Pleistocene hyenas, as they were certainly used by different hyena genera and species (Pachycrocuta brevirostris/Crocuta crocuta spelaea). However, the duration of hyena activity is difficult to estimate. At Koněprusy-Chlupáčova Sluj Cave the macrofauna contains Eemian warm period and Weichselian cold period animals. Hyena clans must have lived in these regions over hundreds of generations and/or in large clans in order to accumulate such a large amount of bones.

Horizontal caves with suitable sizes and access were generally used by the cave bear Ursus spelaeus and the Ice Age spotted hyena $C$. c. spelaea during the Upper Pleistocene. Whereas the cave bears used such simply accessible caves as hibernation and birthing places, the hyenas cleared the caves of cave bear carcasses and occupied them partly or seasonally as den sites (Fig. 8). In many cases they brought in large amounts of prey remains, which were well stored under the cool and humid cave conditions. This prey was also used for the feeding of juveniles who grew up under the protection of the cave den. The bones in these caves are generally much more fragmented and chewed than in the vertical caves. Such sites were found to contain typical nibbling sticks (see definition in Diedrich 2005c, see Fig. 14) from various prey animals ( $c f$. nibbling sticks from the Perick Cave hyena den, Diedrich 2005b-e, g). Unfortunately, such badly preserved bones are not often collected at European cave sites. Upper Pleistocene cave sites of the Bohemian Karst that yielded such hyena nibbling sticks include the Tmaň-Axamitova Brána Cave, Tetín-Turská Maštal Cave, and Hostim-Nad Kačákem Cave. This indicates that these localities were at least periodically used as hyena dens.

The Ice Age spotted hyenas of Europe had a large influence on the bone taphonomy of large Pleistocene mammals. Hundreds of bone deposits in diverse situations have resulted from their activities. These include horizontal caves (e.g., Liebe 1876; Reynolds 1902; Soergel 1937; Diedrich 2005a-f, 2006b), gypsum karst sinkholes (Keller \& Försterling 2002), mud pits in loess (Wernert 1968; Diedrich 2006b), and muddy areas along rivers, which in most cases were not identified as such (Diedrich 2004b). More detailed and systematic research on hyena dens began in southwestern France (Tournepiche et al. 1996, Fosse et al. 1998), where the localities are often mixed with 

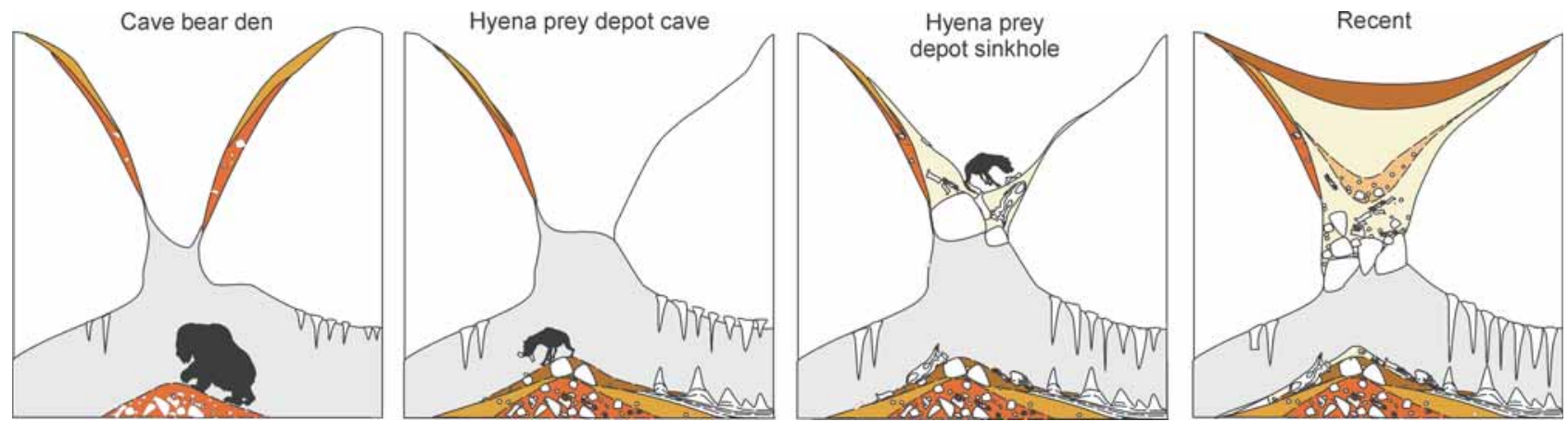

Figure 7. Model of the geological and paleontological history of the hyena prey deposit sites in the Koněprusy Caves-Prošek Dome (left to right). During the Middle Pleistocene parts of the horizontal cave were used by hibernating cave bears, as indicated by U. deningeri bones spread over large areas of Prošek Dome. Middle Pleistocene hyenas scavenged on the carcasses and brought a few prey remains into the cave. The original depositional conditions could have changed significantly, and bear skeletons could have become disarticulated by solifluction. Weichselian permafrost reaching several tens of meters below the surface is indicated in the Bohemian Karst by the study of Žák et al. (2004b). In the Upper Pleistocene, the chimney above Prošek Dome was possibly periodically open and used as a hyena prey deposit. Here, hyena prey remains were deposited for bad feeding times over some decades or centuries.
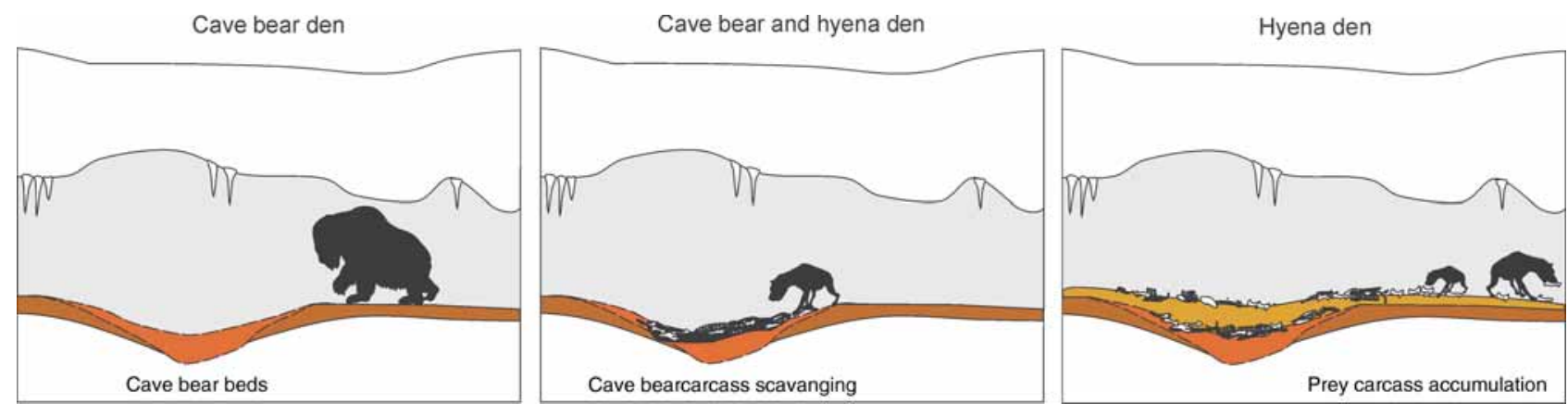

Figure 8. Model of the paleontological history of the cave bear and hyena prey deposit sites, such as the Turská Maštal or Nad Kačákem horizontal caves (left to right). During the Upper Pleistocene, a cave system was used by cave bears for hibernation and giving birth. Here hyenas cleared the caves of animals that did not awaken from hibernation. These caves were used by both bears and hyenas, at least in different periods. Many prey remains were stored here by hyenas over thousands of years.

Paleolithic human sites. The techniques used in the French excavations produced detailed information ( $c f$. Tournepiche et al. 1996). Data of such quality is lacking for the Upper Pleistocene hyena den sites in the Czech Republic because of amateur bone collecting and insufficiently detailed documentation from past excavations. Further overlapping of hyena and human activity has been shown at the Weinberg Caves in southern Germany. At this Paleolithic site, hyenas scavenged mammoth vertebral columns that had been left as waste by humans (Koenigswald 1983, Diedrich 2005c). A non-anthropogenically influenced hyena site in northern Germany that has recently been excavated and well documented contains a hyena prey depot in a gypsum sinkhole, in which hyena coprolites and articulated woolly rhinoceros legs were found among other bone remains and owl pellets (Keller \& Försterling 2002).

During the Ice Age, hyenas used a number of localities for food storage, as shown at various localities in Germany (Diedrich 2004b, 2005g). This is similar to the behaviour of modern African spotted hyenas ( $c f$. Sutcliffe 1970, Avery et al. 1984). The cave-rich Sauerland region of northern Ger- many was one of the first hyena den cave areas to be studied in that country (Diedrich 2005a). The main hyena den sites of this region have been described, the most important of which is the Perick Cave system at Hemer, at which numerous chewed, gnawed and cracked hyena prey bone remains were studied. All these localities are in horizontal caves that were frequented by hyenas who used them as food storages and for protecting their cubs. The same can be observed at four horizontal caves in the Bohemian Karst: Hostin-Nad Kačákem, Tetín-Turská Maštal, Tmaň-Axamitova Brána, and Hlubočepy-Svatoprokopská. The present study is the first to demonstrate that vertical caves served as important, well protected food storage sites, whereas the use of more easily accessible horizontal caves has been recognised since the last century (e.g., Liebe 1876).

\section{Hyena populations}

At least 700 Upper Pleistocene hyena bones, including two skulls of Crocuta crocuta spelaea Goldfuss, were found in 


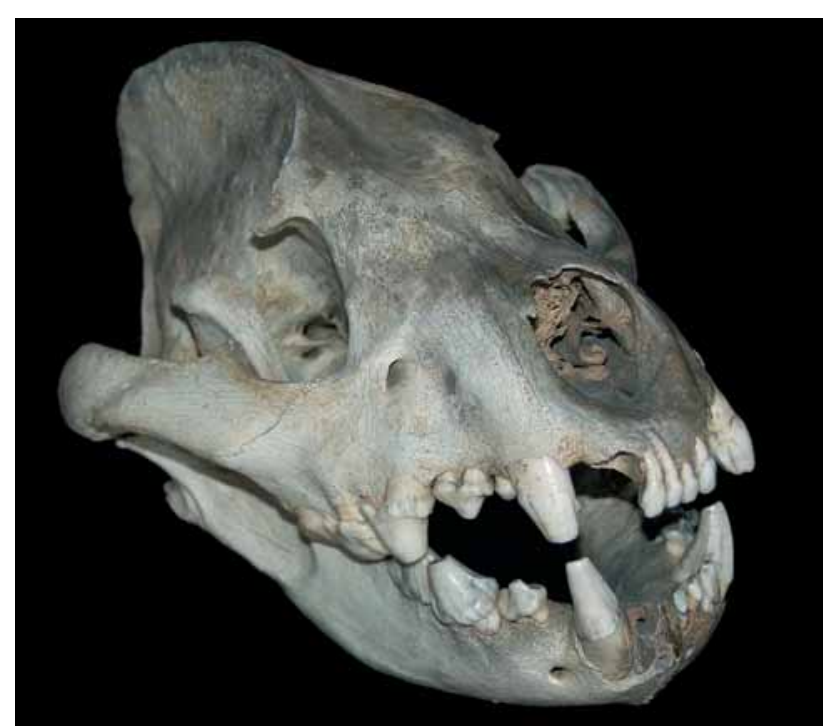

Figure 9. A nearly complete top skull of a high adult hyena Crocuta crocuta spelaea (Goldfuss, 1823) from Srbsko-Chlum-Komín. It is one of the few complete skulls in Europe (NMP No. Ra 1066-mandible/1067-skull).

the seven main cave localities. The minimum number of individuals represented by these bones can be estimated at about 48. The articulated hyena skeletons that were found at Prošek Dome of the Koněprusy Caves and the Srbsko-Chlum-Komín locality are of considerable interest. The most well known material is from the Srbsko-Chlum-Komín site ( 358 hyena bones, MNI = 7 Individuals, estimated on the right humerus). Incomplete skeletal remains of one young adult female and a fully adult male (top skull, Fig. 9) are unique finds from this site. In this cave, some incomplete skeletal remains of juvenile individuals (Fig. 6) can be separated only by finds of long bone material. A nearly complete skeleton (Fig. 5) was collected by J. Petrbok and J. Kovanda in 1950/51 from Prošek Dome of Koněprusy Cave, which was not identified as such and was distributed among several storage boxes. This is one of the most spectacular hyena finds in Europe. Other isolated bones and many coprolites were also collected from the same site, which indicate a MNI of no more then 3 animals (estimated by the left ulnae). About 80 hyena bones and teeth from both Koněprusy-Chlupáčova Sluj and Tetín-Turská Maštal are present in the collections. Furthermore, 40 specimens of bones and teeth from Nad Kačákem Cave, and about 25 from both Reporyje-Kalvárie Cave and Hlubočepy-Svatoprokopská Cave, have been collected in historical times.

Bones of hyenas have been found in many other caves in Europe (e.g., Cuvier 1805, Liebe 1876, Reynolds 1902, Soergel 1937, Heller 1960, Cardoso 1993, Currant 2004, Diedrich 2005a). The paleobiogeographic information described here from the hyena den sites of the Bohemian Karst can be added to future maps of hyena den and prey deposit sites in Europe. At Upper Pleistocene open air sites, such as those of northern Germany, hyena remains are quite rare (Diedrich 2004b, 2006c). The males of C. c. spelae $a$ are slightly smaller than the females, as was described from the German Perick Cave Ice Age spotted hyena population (Diedrich 2005f). A comparison of the Koněprusy Caves-Prošek Dome skeleton (Fig. 5) to the German material indicates that the Koněprusy hyena must have been male (for sexual dimorphism in the Hyaenidae in general see Werdelin \& Solounias 1991; for C. c. spelaea in particular see Diedrich 2005f). The Koněprusy hyena population must have been smaller than that of Srbsko-Chlum-Komín, at which site the largest population of the Bohemian Karst has been found. Recent hyena clans include up to 80 individuals, but in most cases are comprised of about 25 . Usually only about five animals go hunting at a time, and mainly during the night ( $c f$. Kruuk 1970, 1972, Bateman 1987). The recent hyena can smell carcasses from many kilometres away. From the view point on top of Zlatý Kůn̆ Hill near Koněprusy, or at Chlum Hill near Srbsko, hyenas could smell and even watch their prey during the day. The highly exposed nature of the localities seems to have enabled the enormous accumulation of prey bones starting in the Middle Pleistocene (Koněprusy C718 pocket, Koněprusy Cave Prošek Dome, Srbsko Chlum Sluj II-IV).

Two open air sites were partly studied at Münster Bay in northern Germany, a flatland region north of the Sauerland cave-rich mountains. Here, thousands of bones were found in gravel pits at various localities of mostly Upper Pleistocene (Weichselian) age. At two well known Upper Pleistocene sites, Herten-Stuckenbusch and Selm-Ternsche, it became apparent that hyenas were partly or mainly responsible for the large bone accumulations along the Lippe and Emscher Rivers (Diedrich 2004b, 2005d). As with the hyena skeletal remains (Diedrich 2004b), many prey bones are similarly "badly" preserved, such as those found in the hyena den in the Perick Caves. Strongly chewed woolly rhinoceros bones are a good marker for identifying hyena scavenging or den sites, which were later found at the Weser River in northern Germany (Diedrich 2004a). Similarly chewed woolly rhinoceros bones have been observed in Beroun in the Berounka River valley, but also at some places along the Vltava River around Prague, which indirectly indicates the former presence of hyenas.

\section{Carcass import, destruction and bone accumulation}

Upper Pleistocene hyenas dismembered prey carcasses mostly outside of their prey depots, but they also scavenged body parts which were imported into the dens. In some cases they left articulated remains of the prey, which they did not feed on anymore. At the Srbsko-Chlum-Komín 


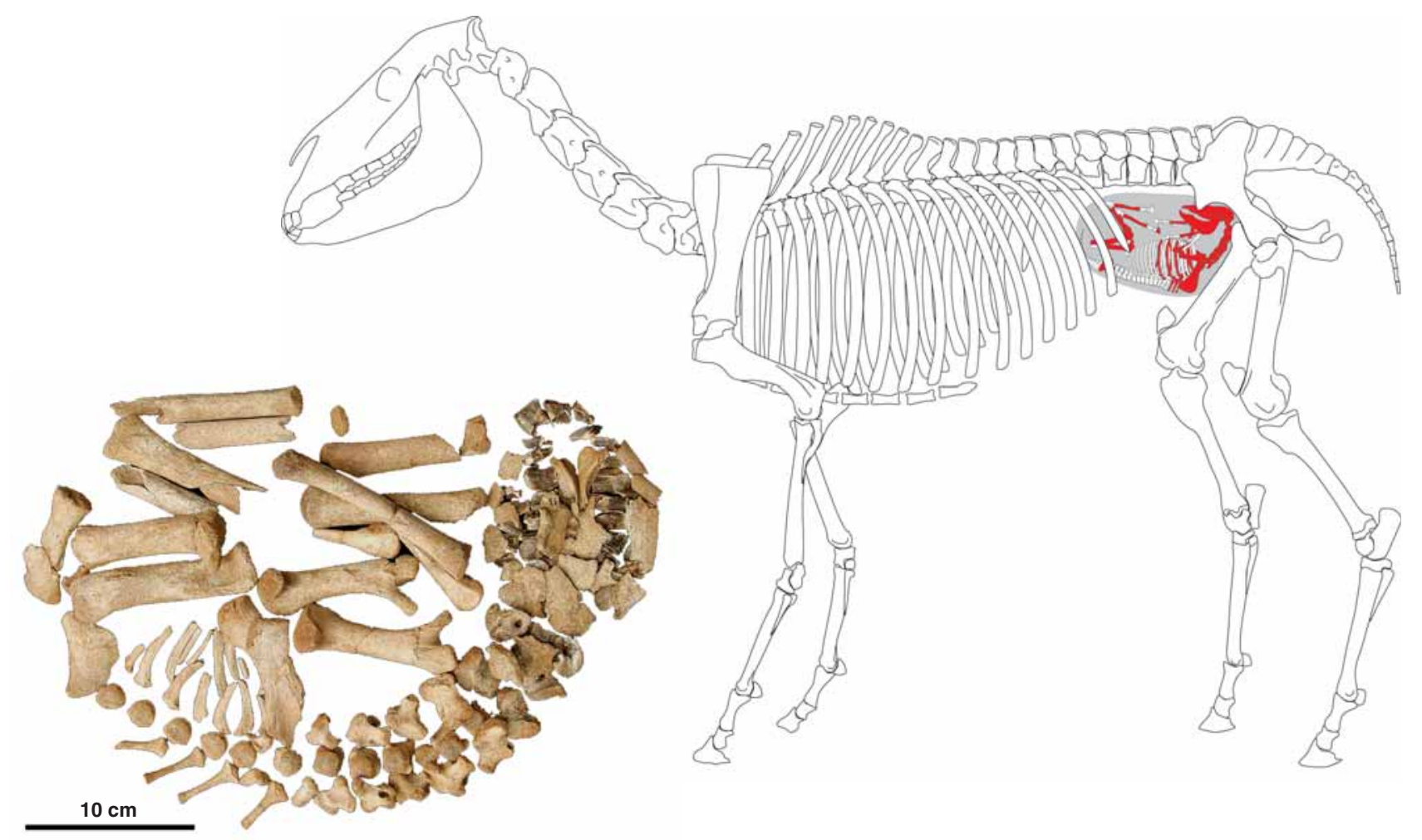

Figure 10. Articulated neonate horse of Equus ferus przewalskii Poljakoff (NMP No. Ra 4211) found in 1969-1971 at the Srbsko-Chlum-Komín hyena den. The top skull is broken into many pieces, including the teeth. The presence of the canines indicates a male individual. This embryo skeleton confirms the active and successful hunting of pregnant horses by hyena clans in late winter to early spring. Adult horses were among the main prey of predators in the Bohemian Karst (cf. Fig. 24A-F).

site, many articulated legs and other body parts (such as vertebral columns) of the following prey were found: $C$. antiquitatis, $B$. priscus, $R$. tarandus, $R$. rupricapra, and mainly E.f. przewalskii.

A complete lower left fore-leg (Fig. 11A) was found well preserved in the Koněprusy Cave-Prošek Dome prey deposit. This leg, and many other bones including the top of the skull, seems to belong to an adult steppe bison, whose carcass was distributed throughout the cave. Quite often the lower legs (metapods and phalangae) of bovids, cervids and equids are found not to have been further cracked by hyenas. In some cases they destroyed the metapods (Fig. 11B, C). Whereas many articulated prey remains were found in vertical caves, the skeletal remains in horizontal caves are nearly all disarticulated. Upper Pleistocene adult horses must have been hunted actively by hyena clans in the Bohemian Karst. It appears that mostly legs were brought into the prey depots, which is typical of hyena activity (Brugal et al. 1997, Fosse 1999, Pickering 2002). Such behaviour is very similar to that of recent African spotted hyenas that hunt mostly zebras, which are sometimes the main food resource (Kruuk 1972, Bateman 1987). Horses seem to have been the main prey in the Upper Pleistocene of the Bohemian Karst, as they are well represented in the prey fauna at all Bohemian caves (cf. Fig. 24A-F). The lower leg bones are quite massive and contained little meat, therefore the hyenas left many of them (partly ulna/radius, and mostly metapods, phalangae and metacarpalia/-tarsalia) untouched and articulated in the hyena den at Srbsko-Chlum-Komín and other sites. They are very common in contrast to femora and humeri, which are often lacking the joints due to hyena feeding activities. The massive metapods were particularly difficult to crack, and also the phalangae were not of much nutritional value. A large accumulation of prey remains could have been produced by hyenas during good hunting seasons. Horse skulls, which are very thin, were easily destroyed, as were the mandibles. This explains why only a large amount of horse teeth were left after the scavenging activity at many hyena den sites in the Bohemian Karst or German Sauerland ( $c f$. Diedrich 2005b).

Finds of nearly complete, articulated skeletons of prey are very rare. The most spectacular find is a nearly complete neonate horse skeleton (Fig. 10). This find, along with very few remains of three other neonate individuals, provides information about the hunting season (late winter to early spring) and the feeding habits (kills of pregnant females) of the hyenas.

Nearly complete steppe lion skeletons at the Srbsko-Chlum-Komín site and Kobyla-Chlupáčova Sluj 

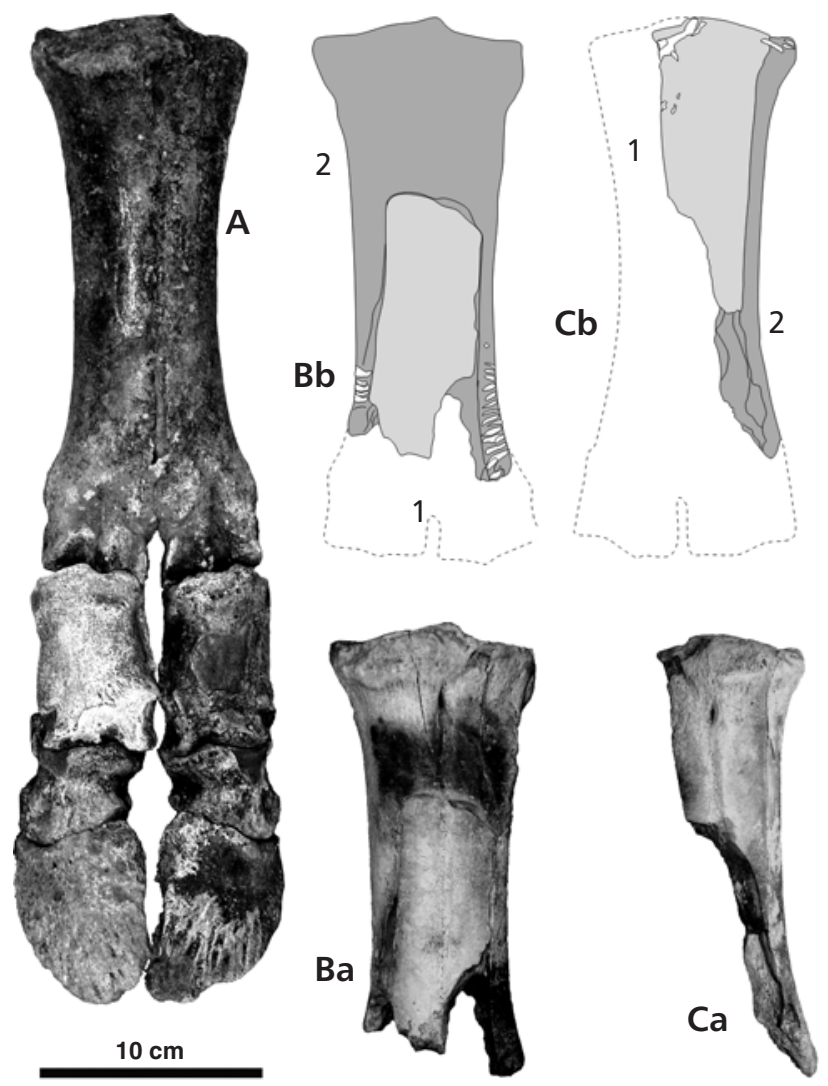

Figure 11. Steppe bison Bison priscus Bojanus forelimb remains. $\bullet$ A articulated left forelimb from Koněprusy Caves-Prošek Dome (left metacarpal NMP No. R 2450, right phalanx 1 NMP No. R 2450, left phalanx 1 MBKB No. Ra 4216, right phalanx 2 NMP No. R 3296, left phalanx 2 NMP No. Ra 4217), right phalanx 3 NMP No. R 3317, left phalanx 3 NMP No. R 3316. - B-C - cracked metacarpal bones from Srbsko-Chlum-Komín, which seem to be from one scavenged bison. The long bones were crushed into pieces by hyenas and found in the den. They confirm the bone cracking activities in the vertical cave itself. - B cracked, left metacarpal (NMP No. R 5417). • C - right cracked metacarpal (NMP No. Ra 4207). a-photo, b-redrawing. 1 and 2 bone fragments which are fitting together.

Cave are unique finds. At the first site, an adult female lion was found with a strong cranial fracture, which was in the process of healing (Fig. 12). Such an injured lion would have been an easy kill for a hyena clan. A juvenile individual from that site is also nearly complete. At Chlupáčova Sluj Cave the remains of a very young steppe lion were formerly misidentified. Questions as to why articulated, nonscavenged steppe lion remains are found in hyena den sites gave rise to the out-dated "cave lion" interpretation (cf. e.g., Dawkins \& Sandfort 1900). These lions never used caves, though $P$. leo spelaea bones have been found in caves all over Europe (e.g., Kafka 1903, Schütt 1978, Gross 1992, Baryshnikov \& Boeskorov 2001, Diedrich 2004c). Their taphonomy in most cases is not well understood. It is interesting that steppe lion remains mostly occur at hyena den sites, such as those of the Sauerland region

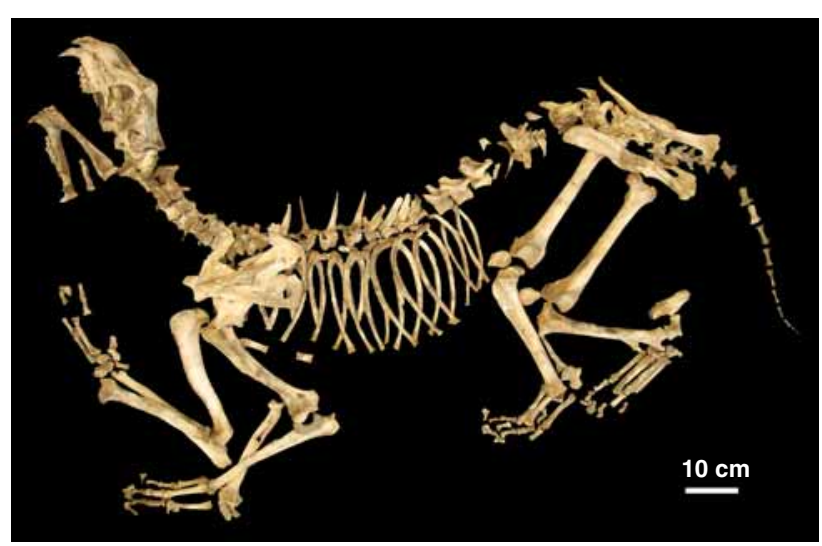

Figure 12. Articulated female steppe lion Panthera leo spelaea (Goldfuss, 1810) skeleton found mainly in 1969 by the excavations of the Speleoclub in Srbsko-Chlum-Komín (NMP No. R 4406). The cranium has a pronounced pathology, which was in the process of healing. This injured, early adult lion would have been easy prey for a hyena clan. Otherwise is could have been moved postmortally into the hyena den, though shows no hyena scavenging marks. It is possible that the animal climbed down into the vertical cave and became trapped; the cave was full of hyena prey, on which the injured lion could have fed. This female lion survived the brain case fracture for several weeks.

(cf. Diedrich 2004c, 2005f). The actuopaleontological comparison to the conflicts between modern spotted hyenas and lions gives a possible answer. In the Serengeti, $50 \%$ of hyena kills are caused by lions, and most lion kills result from conflicts with hyena clans over fresh carcasses or the protection of their young (Kruuk 1970, 1972; Bateman 1987). Hyenas never kill the stronger male animals, whereas females are sometimes the victims of a hyena clan. The female lion skeleton that was found among the remains in the hyena prey deposit of Srbsko-Chlum-Komín might prove such a conflict.

Hyenas and lions do kill each other, but they mostly do not scavenge the carcasses. There are therefore two possibilities as to why Upper Pleistocene steppe lion skeletons (or remains thereof) are commonly found in hyena den sites and prey deposits. First, they could have been killed by hyena clans directly at the den sites as a result of defending their prey. This could have happened to the female lion with the injured skull (Srbsko-Chlum-Komín find). The fracture of the parietal also caused a partial fusing of the sutures between the parietal and frontal. Such an injury would have prevented this steppe lion from being able to hunting successfully, causing it to search for carcasses on which to feed. Secondly, the lions could have been killed elsewhere by the hyena clan, and their carcasses were brought into the prey deposit sites, but not scavenged. This scenario may be especially likely for the juvenile lions. Though carnivorous mammals do not generally feed on other carnivores, hyenas are an exception, and are even cannibalistic ( $c f$. Bateman 1987, Frank 1994). Either way, these three steppe lions - two juveniles 
and one injured adult female - must have been easy prey for hyena clans.

In the Bohemian Karst, thousands of bones of mainly non-cave animals were found in the main Upper Pleistocene localities the Srbsko-Chlum-Komín, Kobyla-Chlupáčova Sluj Cave, Koněprusy Caves-Prošek Dome, Hostim-Nad Kačákem Cave, and Tetín-Turská Maštal Cave sites. All other caves have delivered less than about one hundred bones. Human influences on bone accumulations in the caves seem to have been minor before the Magdalenian period. Reports on the presence of earlier human groups (e.g., Gravettian) have been partly revised, and are confirmed only in a few cases (Fridrich \& Sklenář 1976). Many open air and cave sites from the Late Paleolithic (18,000-14,000 BP) have been described from the Bohemian Karst (Vencl 1995). The layers containing artefacts mostly occur above the bone rich layers from hyena and cave bear times (Middle and Upper Pleistocene).

The hyenas played the most important role in the destruction and accumulation of bones during the Pleistocene in the Bohemian Karst region. In some cases it is unclear whether the hyenas stored prey in karst depressions above vertical caves, or if they climbed more deeply into the steeper cave sections. The taphonomy of bones and feeding habits of hyenas from the Late Weichselian becomes clearer with the study of the gnawing, nibbling and cracking marks on bones.

The "bone habits" of the recent African spotted hyenas C. c. crocuta Erxleben, which have been well studied (e.g., Kruuk 1970, 1972; Bateman 1987; Frank 1986a, b; Hofer \& East 1995; Brugal et al. 1997), seem to be analogous in many ways to the activities of the Upper Pleistocene $C$. c. spelaea (Goldfuss), such as the storing of prey in caves and open air sites, the manner of bone destruction during feeding, and the moving of prey remains to cubs at the den sites. Prey and bone accumulations by the recent spotted hyena $C$. c. crocuta are very well known from open air sites in Africa (Sutcliffe 1970, Henschel et al. 1979, Behrensmeyer \& Boaz 1980, Brain 1980, Scott \& Klein 1981, Avery et al. 1984, Skinner et al. 1986, Cooper 1993, Brugal et al. 1997, Di Silvestre et al. 2000). For the Upper Pleistocene of Europe, such accumulations are not often mentioned. This is the case at some German open air loess sites such as Achenheim (Wernert 1968), Bad Wildungen-Biedensteg (Diedrich 2006b-d), and the Morschen-Konnefeld gypsum karst sinkhole site (Keller \& Försterling 2002). Many hyena dens and deposits have been described in a small cave-rich region of southwestern France (Fosse et al. 1998). In the Sauerland of northern Germany, many hyena den sites have only recently been identified as such (Diedrich 2005a). Finally, a few hyena den cave sites from southern England are mentioned by Reynolds (1902), and were recently restudied by Currant (2004).
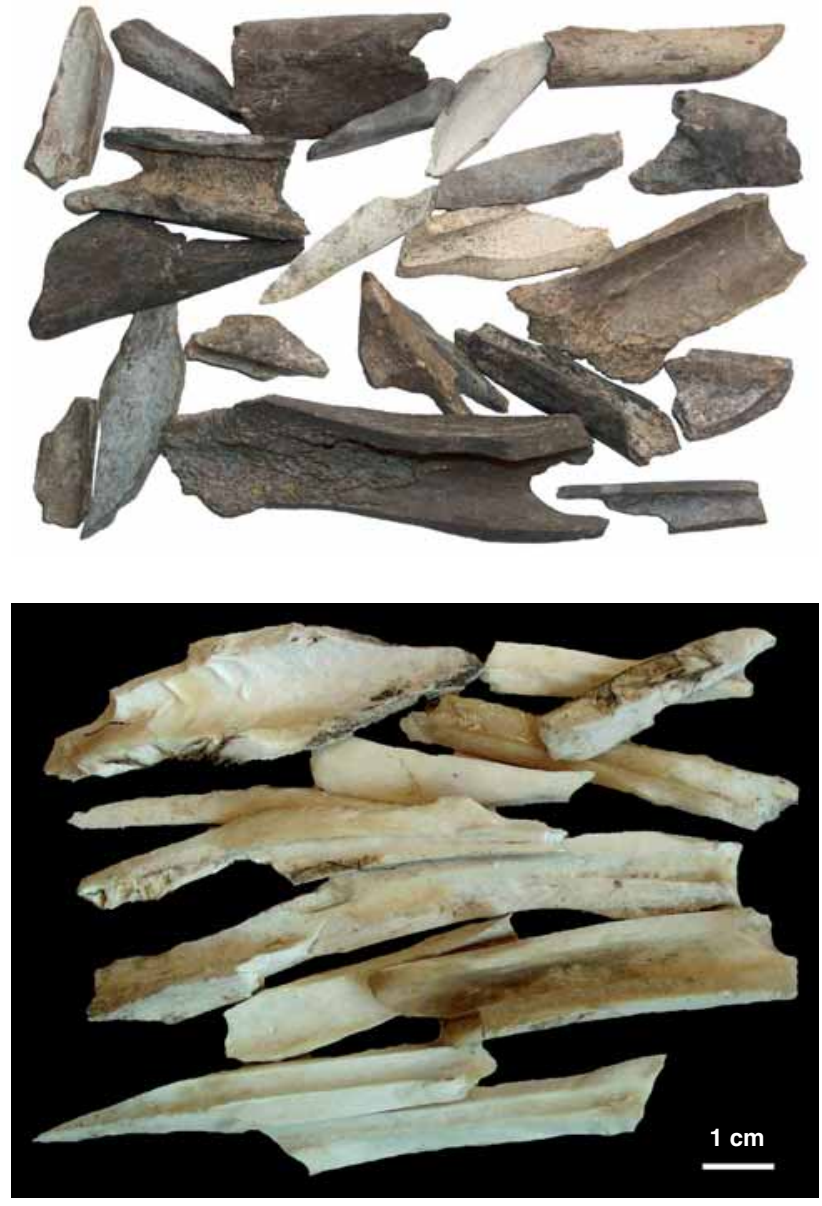

Figure 13. The results of bone cracking by hyenas. The main reason for cracking the bones is to obtain the marrow as nutrition, but small bone fragments can also be digested by hyenas. Upper: Cracked bones of $R$. $t a-$ randus, E. f. przewalskii, M. giganteus and other animals from the Upper Pleistocene hyena den at Koněprusy Caves-Prošek Dome, Czech Republic (NMP No. Ra 4213). Lower: Cracked zebra and antelope and other long bone fragments from a recent hyena den in the Ngorongoro Crater, Tanzania (Sutcliffe, coll. BMNHL).

\section{Bone cracking and chewing}

Large amounts of bone fragments are very typical of hyena dens, such as those of Upper Pleistocene fauna found at the Koněprusy Caves-Prošek Dome and Nad Kačákem Cave. In some cases, as at Srbsko-Chlum-Komín, the ratio between cracked bones and complete bones is inverted. At that locality, only a few percent of the bone material are fragments. The documentation and further study of such fragments are important for the understanding of prey deposit sites and the identification of hyena dens.

Bones showing bite marks and cracking structures are very common in the Upper Pleistocene material from the Bohemian Karst, as was recognized in some cases by Fejfar (1958, 1961a, 1961b). They are comparable to cave and open air sites in Germany. Detailed studies of chewed 
and cracked bones from a bone rich hyena den cave in the Sauerland of northern Germany have shown the typical prey bone taphonomy ( $c f$. Diedrich 2005a, b, 2006b), which is important for identifying hyena-related bone accumulations. The bones show the feeding habits of the hyenas, which seem to vary according to prey group (bovids, cervids, proboscids, carnivores, rhinocerids) and their bone types. Prey bones of cervids and bovids, and even of other hyenas, could be cracked easily by the Ice Age spotted hyenas (Fig. 13), which is well documented in the Perick Caves (Diedrich 2005b, d, e). Such bone cracking can be observed in recent hyena populations and den sites in Africa, such as in the Ngorongoro Crater of Tanzania (Fig. 13). The hyenas destroyed the bones to obtain the marrow, used bone fragments as nibbling sticks, and even swallowed bone pieces completely (see Fig. 25). Only hyenas can digest bone collagen and use it as a nutrition source (Kruuk 1972). The bone-cracking activities of $P$. brevirostris in the Middle Pleistocene, and of $C$. c. spelaea in the Upper Pleistocene, resulted in the fragmented bones found at most cave sites in the Bohemian Karst. Bone-cracking activities inside a den are demonstrated by a steppe bison femur and two metacarpals that are cracked into pieces (Fig. 11B, C). These fragmented bones from the Upper Pleistocene by can be partly fitted together, as can other bone fragments representing scavenged reindeers and other hyenas. These examples provide impressive demonstration of the bone-cracking activity inside the
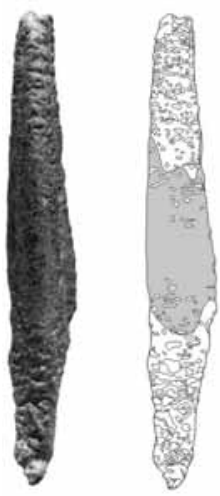

$\mathrm{Aa}$

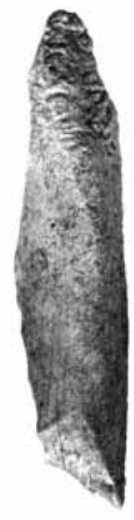

$\mathrm{Ba}$

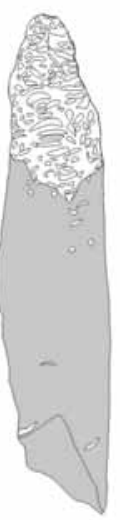

$\mathrm{Bb}$

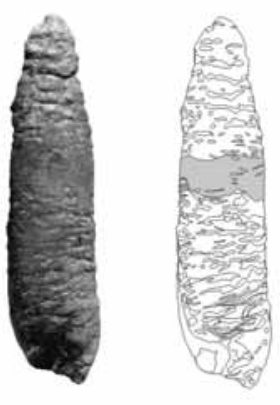

Ca

$\mathrm{Cb}$

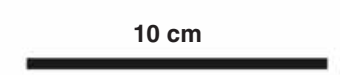

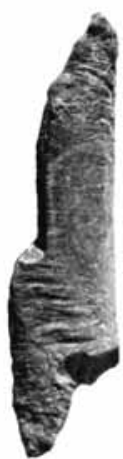

$\mathrm{Da}$

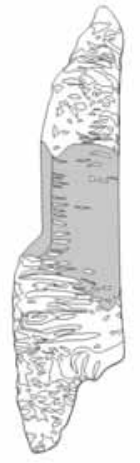

Db

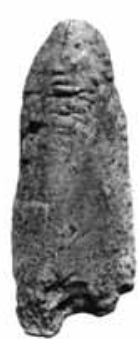

Ea

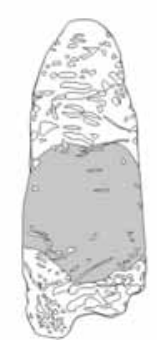

$\mathrm{Eb}$

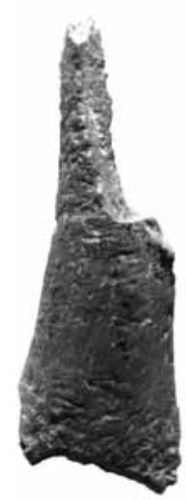

$\mathrm{Fa}$

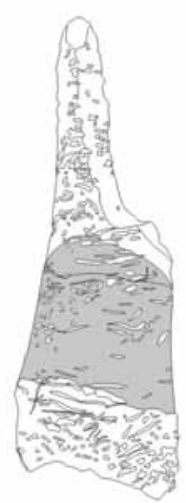

$\mathrm{Fb}$

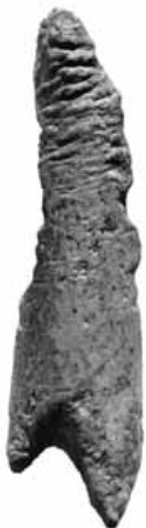

Ga

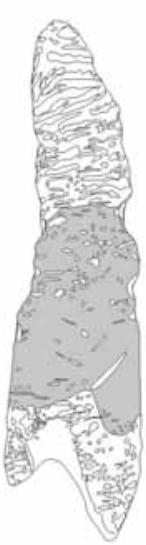

Gb

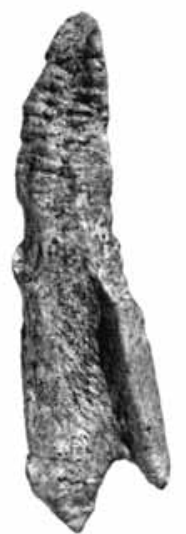

Gc

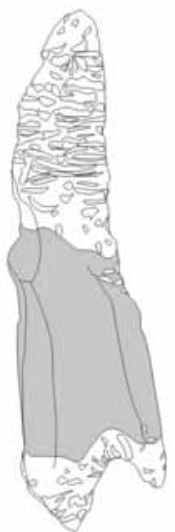

Gd
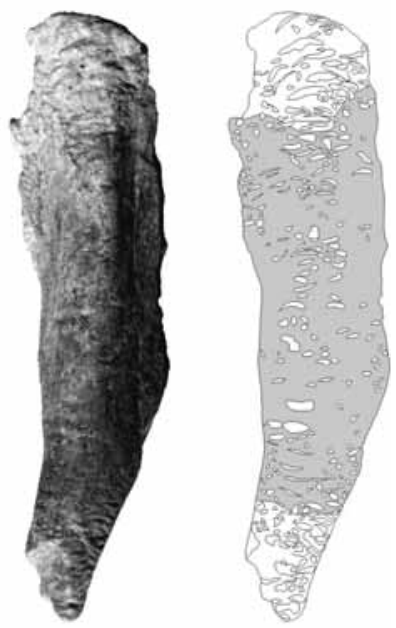

$\mathrm{Ha}$

$\mathrm{Hb}$

Figure 14. Nibbling sticks: intensively chewed bone fragments from the hyena den Nad Kačákem Cave. Such bone pieces are more common in horizontal cave den sites, where juvenile hyenas chewed on the bones for nutrition and for teething. $\bullet$ A - long bone fragment of a bovid/cervid (NMP No. Ra 4198). • B - tibia fragment of Equus ferus przewalskii (NMP No. Ra 4205) • C - metapod fragment from Equus ferus przewalskii (NMP No. Ra 4201). D - metapod fragment from Equus (NMP No. Ra 4200). E - non-identified long bone fragment (NMP No. Ra 4197). $\bullet$ - ? B. priscus humerus fragment (NMP No. Ra 4203). $• \mathrm{G}$ - femur fragment of Ursus spelaeus (NMP No. Ra 4199). H - radius fragment of Coelodonta antiquitatis (NMP No. Ra 4196). 
Srbsko-Chlum-Komín den site, and explain the bone fragment accumulations in hyena den cave sites generally.

The comparison of horizontal hyena den caves to vertical caves in the Bohemian Karst show a general difference in the bone preservation. As hyenas generally grew up in horizontal caves, its stands to reason that prey remains in such places would show a higher degree of destructive activity, which is documented at the Hostim-Nad Kačákem Cave and Tetín-Turská Maštal. In contrast, hyenas were unable to destroy all the prey remains in vertical caves, such as at Srbsko-Chlum-Komín. The various remains from these sites were probably found in anatomical context (Fig. 12), but were collected without proper documentation. The study and reorganization of the NMP bone collec- tion has shown that many of the haphazardly collected bones fit together into articulated lower fore- and hindlimb remains.

\section{Bone nibbling}

Nibbling sticks are bone fragments that were strongly chewed from one or two sides (see definition in Diedrich 2005c). Hyenas they left abundant nibbling sticks in horizontal caves, though they are mostly absent in vertical caves (as documented at Srbsko-Chlum-Komín).

Various bone fragments were used for this purpose, apparently with little selectiveness. Long bone fragments

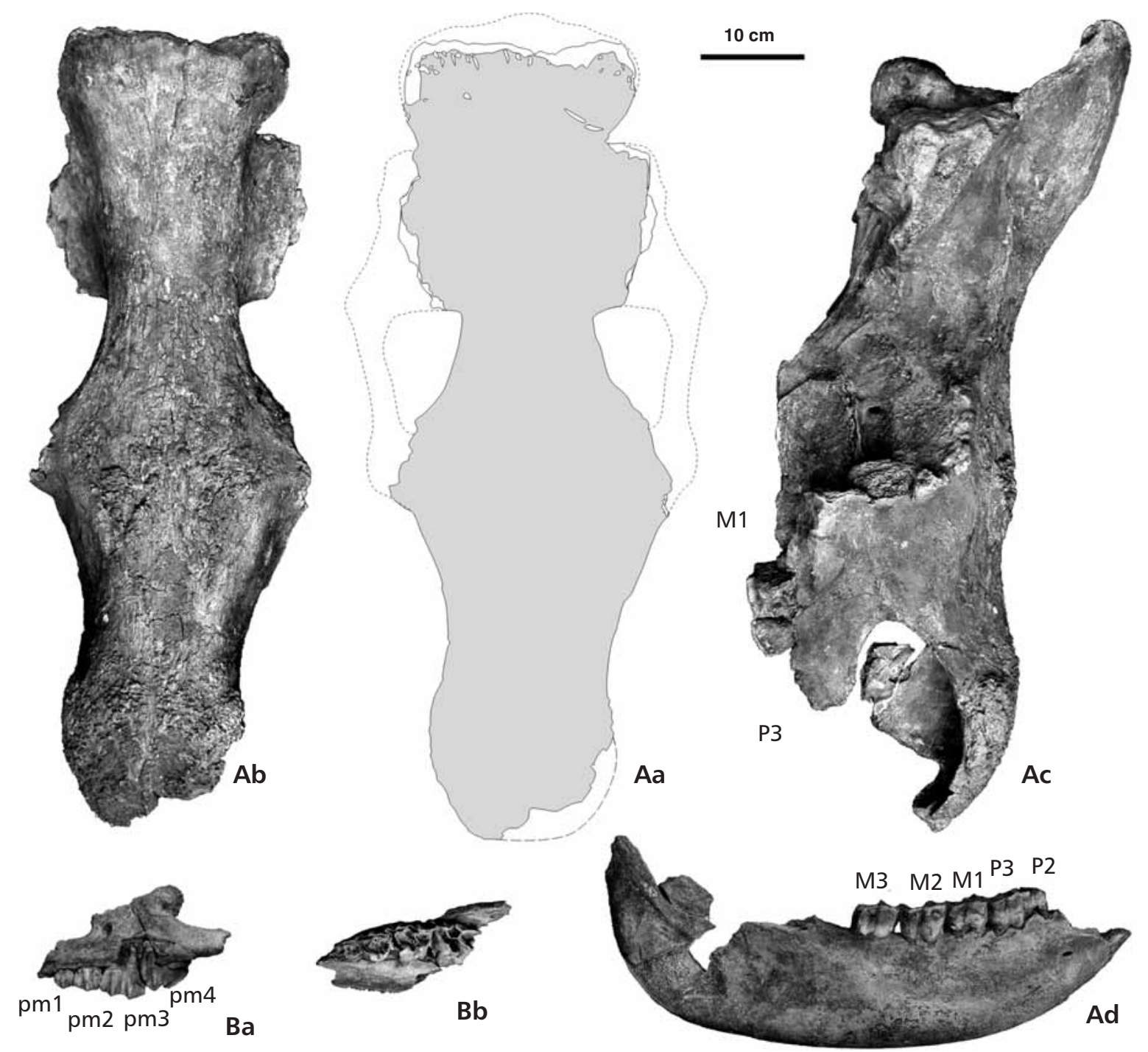

Figure 15. Examples of skulls of the woolly rhinoceros Coelodonta antiquitatis Blumenbach with hyena chewing and nibbling marks. These were found at various hyena den and prey depot cave sites in the Bohemian Karst. $\bullet$ A - top skull with right mandible which was chewed at the occipital, from Koněprusy Caves-Prošek Dome (NMP No. R 2054). Both jugals were also cracked and chewed off. a-b - top skull, dorsal, c - top skull, lateral right, d right mandible, lateral right. • B - fragment of the left maxillary with full milk dentition of a juvenile woolly rhinoceros from Turská Maštal Cave (NMP No. R 2517). a - lateral, b - ventral. 
of Equus ferus przewalskii (Fig. 14C, D), Bison priscus (Fig. 14F), Coelodonta antiquitatis and even Ursus spelaeus were used as nibbling sticks in the Nad Kačákem Cave. However, favourites for such purposes seem to have been the medium massive longbone fragments of cervids (M. giganteus, C. elaphus, but rarely $R$. tarandus, $c f$. Diedrich 2005e), and bovids (B. priscus, cf. Diedrich 2005d). Due their structure, the bones of the woolly rhino were hearly impossible to crack, and bone fragments or nibbling sticks from Coelodonta (Fig. 14H) are therefore quite rare. The use of cave bear bones for nibbling has been discerned in Nad Kačákem Cave (Fig. 14G), which is also documented from $U$. spelaeus bones in the Perick Cave hyena den (Diedrich 2005g). Such chewed prey bone fragments are abundant in the Nad Kačákem Cave (Fig. 14).

The coincidence of a high number of nibbling sticks in hyena den sites and the presence of many bones of juveniles, e.g., at Nad Kačákem Cave and Turská Maštal Cave, led us to believe the cubs to be the main producer of such characteristic bone fragments. In hyena prey depots such as Srbsko-Chlum-Komín, where thousands of bones and even fragments are present, not one nibbling stick was found. Though prey was stored in vertical caves, it seems that cubs did not have easy access to them. In the Nad Kačákem Cave, hyena cubs grew up and seem to have used bone fragments to chew on intensively. Such chewing is very typical for all kind of carnivores, especially when growing new teeth. The milk dentition of hyenas can produce long, deep scratches, whereas the posterior teeth can produce triangular to oval shaped grooves on the bone surface. Both types of bite mark occur frequently on the nibbling sticks figured here.

\section{Killers and scavengers of the woolly rhinoceros}

Hundreds of Coelodonta antiquitatis bones were found in the hyena den sites in the Bohemian Karst. The most well known accumulations were discovered at the localities of Srbsko-Chlum-Komín, Koněprusy Caves-Prošek Dome, and Kobyla-Chlupáčova Sluj Cave. In some cases long bones could be fitted together (Figs 17, 18), which indicate originally articulated legs. Even three skulls had articulated lower jaws. A skull (Figs 15, 16) was found in one piece in the Koněprusy Caves-Prošek Dome (cranium with lower jaw, adult animal). There were two other finds of crania with lower jaws at Srbsko-Chlum-Komín (an adult and a late juvenile), and one with a fragmented skull top from the Hlubočepy-Svatoprokopská Cave. The woolly rhinoceros material is generally incomplete and strongly chewed. The chewing activities of the hyenas are demonstrated best on woolly rhinoceros bones, and such bones are typical markers for hyena den/prey depot sites in caves and open air areas. Therefore this material is figured here in detail for the first time, showing typical chewing marks and missing joints.

Hyenas must have removed a few complete skulls with jaws from carcasses of $C$. antiquitatis (Figs 15, 16). Juvenile skull remains from the Turská Maštal Cave are interpreted as hunted prey (Fig. 15B). This woolly rhino calf had full milk dentition and was less then one year old. A very similar find of a woolly rhinoceros skull of the same age was found at the open air hyena den site Bad Wildungen-Biedensteg in Germany (Diedrich 2006b). Both animals and additional postcranial finds at both of the above-mentioned hyena den sites support the conclusion that hyena clans hunted woolly rhino calves. Impressively, hyenas must have moved even complete skulls of adult individuals into their den sites, as shown at the Koněprusy Caves-Prošek Dome (Fig. 15A) and the Srbsko-Chlum-Komín (Fig. 16) site. It is unclear, however, if the rhino skulls came from hunted or scavenged victims.

The skull found at Koněprusy shows typical chewing on the occipital region. Such bite marks could indicate the cutting of the skull from the postcranial outside the cave. Additionally the jugals are chewed off completely. The destruction of the jugals by hyenas is very common on all kinds of prey, even on the skulls of hyenas that the others preyed upon ( $c f$. Diedrich 2005f, 2006c). The lower jaws must be cracked or chewed out of their joints. In this case the chewing must have happened in the prey deposit cave itself, where the lower jaws were also found. A similar situation occurs with two top skulls of differently aged individuals from the Srbsko-Chlum-Komín Cave.

The adult animal skull (Fig. 16A) lacks the left jugals, which were clearly chewed away. The left lower jaw that fits this skull lacks the ramus, which was chewed off, but also shows signs of proximal nibbling. These skulls prove that hyenas repeatedly removed the lower jaws in the same way. Such impressive skull importation into hyena dens and the feeding strategy on $C$. antiquitatis skull tops is shown here for the second time in Europe.

A juvenile skull with lower jaws and braincase opened for feeding on the brain marrow was recently described from the hyena open air prey deposit site at Bad Wildungen-Biedensteg (Diedrich 2006b). Additionally, some strongly chewed woolly rhino skull remains were described by Heller (1962) from other German cave sites.

At many hyena deposit and den sites of the Bohemian Karst, and at open air loess sites around Prague, articulated longbones, such as the ulna/radius or tibia/fibula (Figs 17, 18), indicate body parts brought into the den sites in an originally complete condition. Such taphonomical situations are known from hyena den and prey deposit sites in Germany (Keller \& Försterling 2002, Diedrich 2006b). The longbones are filled with bone spongiosa and the compacta is thick in the bone shaft, so that even hyenas 

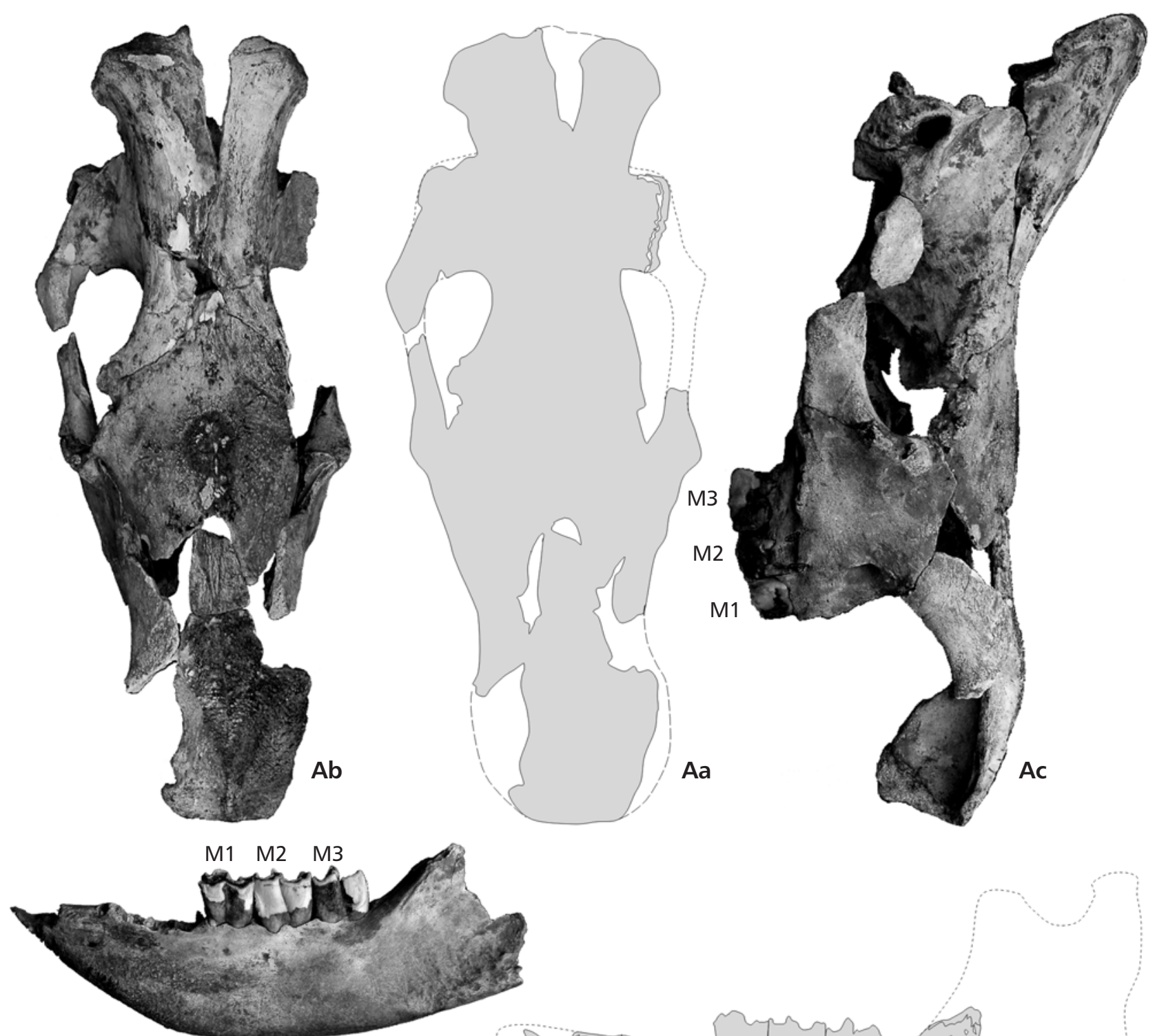

$\mathrm{Ad}$
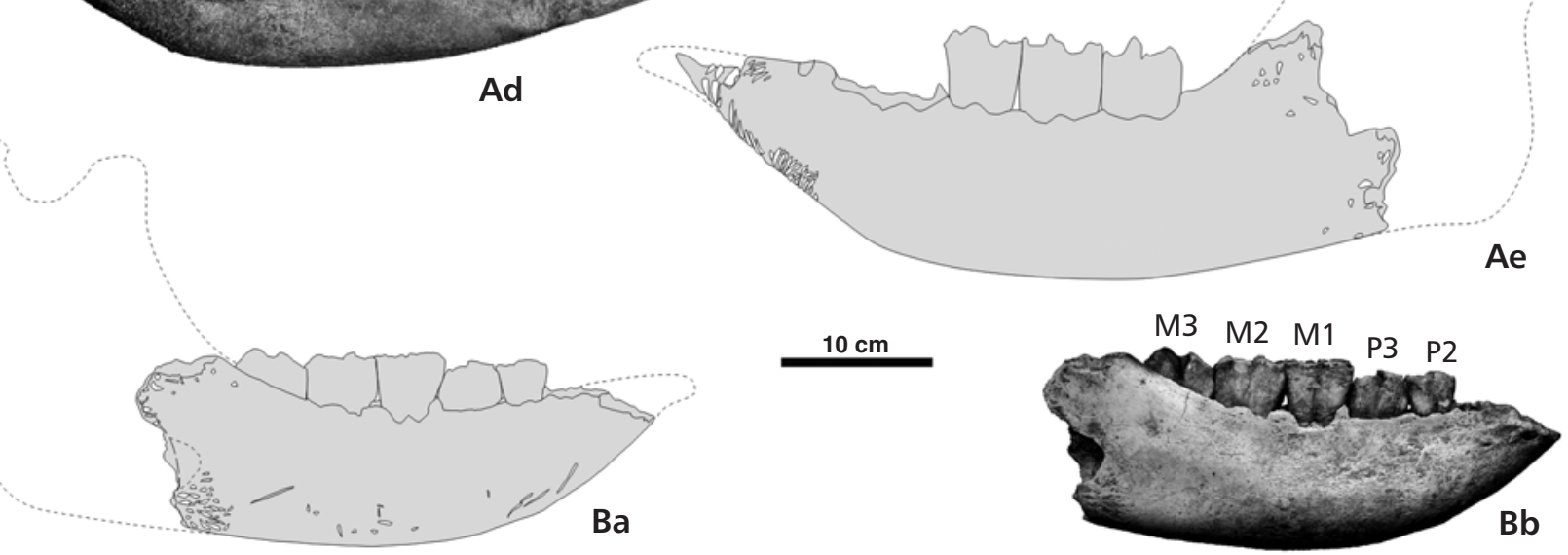

Figure 16. Skulls of the woolly rhinoceros Coelodonta antiquitatis Blumenbach with hyena chewing and nibbling marks. These were found at various hyena den and prey depot cave sites in the Bohemian Karst. • A - top skull, fragmented during the excavations from Srbsko-Chlum-Komín (NMP No. Ra 3383). The left jugals were chewed off. The ramus of the mandible was cracked and chewed, and the anterior part shows nibbling marks. a-b - top skull, dorsal, c - top skull, lateral right, d-e - left mandible, lateral left. $-\mathrm{B}$ - mandible of a juvenile animal in tooth change of the P3 and M3 from Srbsko-Chlum-Komín Cave (NMP No. Ra 3356). The top skull to this jaw is present, but is fragmented. a-b - lateral, c - dorsal. 
were generally unable to crack them. This is why hyenas only chewed on the joints and left the middle bone shaft of the long-bones of the humerus (Fig. 17A-C), ulna and radius (Fig. 17D-H).

The same incomplete preservation of bones missing their joints occurs with the femora (Fig. 18A, B) and tibia or fibula (Fig. 18C-F), and with the massive acetabular part of the pelvis (Fig. 18I). Clear chewing marks are often found on the astragals, represented here by two finds in Axamitova Brána Cave and Srbsko-Chlum-Komín (Fig. 18G, H). Even articulated metapods are present in three caves (Turská Maštal, Koněprusy Caves-Prošek Dome, Srbsko-Chlum-Komín), of which metacarpals of from Srbsko-Chlum-Komín are figured here (Fig. 17I). Such typically chewed woolly rhino prey remains were found in the seven Bohemian Karst hyena den and prey deposit caves, and at many open air loess sites around Prague that also seem to have been of hyena prey deposit origin (Fig. 2). Many well chewed bones are present from Srbsko-Chlum-Komín and the Koněprusy Caves-Prošek Dome, and smaller numbers from Nad Kačákem and Turská Maštal, Řeporyje-Kalvarie and Hlubočepy-Svatoprokopská Cave. These longbones are in exactly the same condition as bones from the Perick Caves and Bad Wildungen-Biedensteg sites (Diedrich 2006a, b). Such typically chewed woolly rhinoceros bones were also found at open air sites in Beroun and Karlštejn along the Berounka river valley in Bohemia (unpublished material in the MBKB collection), and at some loess sites around Prague along the Vltava River valley (Fig. 2, NMP material). Bones that have been recently accumulated by the African hyena $C$. c. crocuta were found in their cave dens, and show exactly the same incomplete preservation (Fig. 19) as the Pleistocene material described above. The missing joints and irregular margins of the bone shafts, and the massive left central bone part of recent and fossil rhinoceroses are identical. The modern humerus in Fig. 19 and the Pleistocene humerus in Fig. 17C show typical and repeating stages of chewing. Both the Upper Pleistocene and recent hyenas seem to show the same feeding strategy concerning rhinoceroses. The presence of neonate animal remains in modern African hyena den caves (Fig. 19) fits the hunting interpretations of the Pleistocene hyenas of the Bohemian Karst.
Hyenas fed mainly on woolly rhinoceros carcasses in the Bohemian Karst and throughout central Europe. In the open air site at Bad Wildungen-Biedensteg, carcasses of a young adult female and a calf were found in a completely disarticulated state. The bones must have been partly articulated and were strongly chewed, as in many of the Bohemian Karst caves. Additionally, the remains of at least eight individuals have been found in loess sediment at Bad Wildungen-Biedensteg in exactly the same incomplete state as the woolly rhinoceros remains from all seven Bohemian hyena prey deposit and den caves described here. Similar finds have been made at many European caves and open air hyena dens or scavenging sites (Wernert 1968, Keller \& Försterling 2002, Diedrich 2006b).

\section{Cave bear scavengers}

At the Tmaň-Axamitova Brána, Tetín-Turská Maštal, and Hostim-Nad Kačákem Caves, many bone fragments, nibbling sticks, chewed longbones, and vertebrae or jaws of Ursus cf. spelaeus were found (Fig. 20). Cave bears must have hibernated at these localities, where articulated skeletal remains were left. Some connected bones, such as a vertebral column, were found in articulation (Fig. 20C). Further confirmation of the use of these caves as bear dens comes from the large number of juvenile remains, indicated by the teeth and jaws, in the museum collections.

Whether the cave was used by different carnivores during the same time is unclear, but it is apparent that hyenas fed on cave bear carcasses in the caves, or brought carcass remains into open air karst depressions or mud pits (cf. Diedrich 2005g). Hyenas must have scavenged cave bears in various caves throughout Europe, as was recently indicated by finds at the Perick Caves (Diedrich 2005g). They also fed on cave bears and possibly imported carcass remains into open air prey deposit sites, which is documented at Bad Wildungen-Biedensteg (Diedrich 2006d). The longbones found at open air and cave sites are typically without joints or are cracked into many pieces. In a few cases, hyenas used them as nibbling sticks (Fig. 14G). At some bone deposits in the Bohemian Karst, such as at the vertical cave and hyena den Koněprusy-Chlupáčova Sluj, it seems that bear carcass remains were not often car-

Figure 17. Examples of chewed woolly rhinoceros Coelodonta antiquitatis Blumenbach fore limb bones found at various hyena den and prey depot cave sites in the Bohemian Karst. The joints of the long bones were generally chewed off, often completely at both sides. Hyenas left characteristic bone remains at all localities. Articulated limb bones indicate the bringing of limbs and body parts into the den/prey depot sites. a - photo, b - redrawing. • A - right humerus from Koněprusy Caves-Prošek Dome (NMP No. Ra 4194). • B - right humerus from Turská Maštal Cave (NMP No. Ra 4277). • C - right humerus from Srbsko-Chlum-Komín (NMP No. Ra 3389). • D - articulated right ulna/radius from Koněprusy Caves-Prošek Dome (NMP No. Ra 4153-radius/4152-ulna). • E - articulated left ulna/radius from Srbsko-Chlum-Komín (NMP No. Ra 3385/3381). • F - right ulna from Nad Kačákem Cave (NMP No. R 9379). • G - right radius from Nad Kačákem Cave (NMP No. R 9378). • H - left radius from Turská Maštal Cave (NMP No. Ra 4276). I - articulated right metacarpals of one animal from Srbsko-Chlum-Komín (NMP No. mc IV-R 5077, mc III-R 5012, mc II-R 5075). 
Cajus G. Diedrich \& Karel Žák • Prey deposits and den sites of the Upper Pleistocene hyena
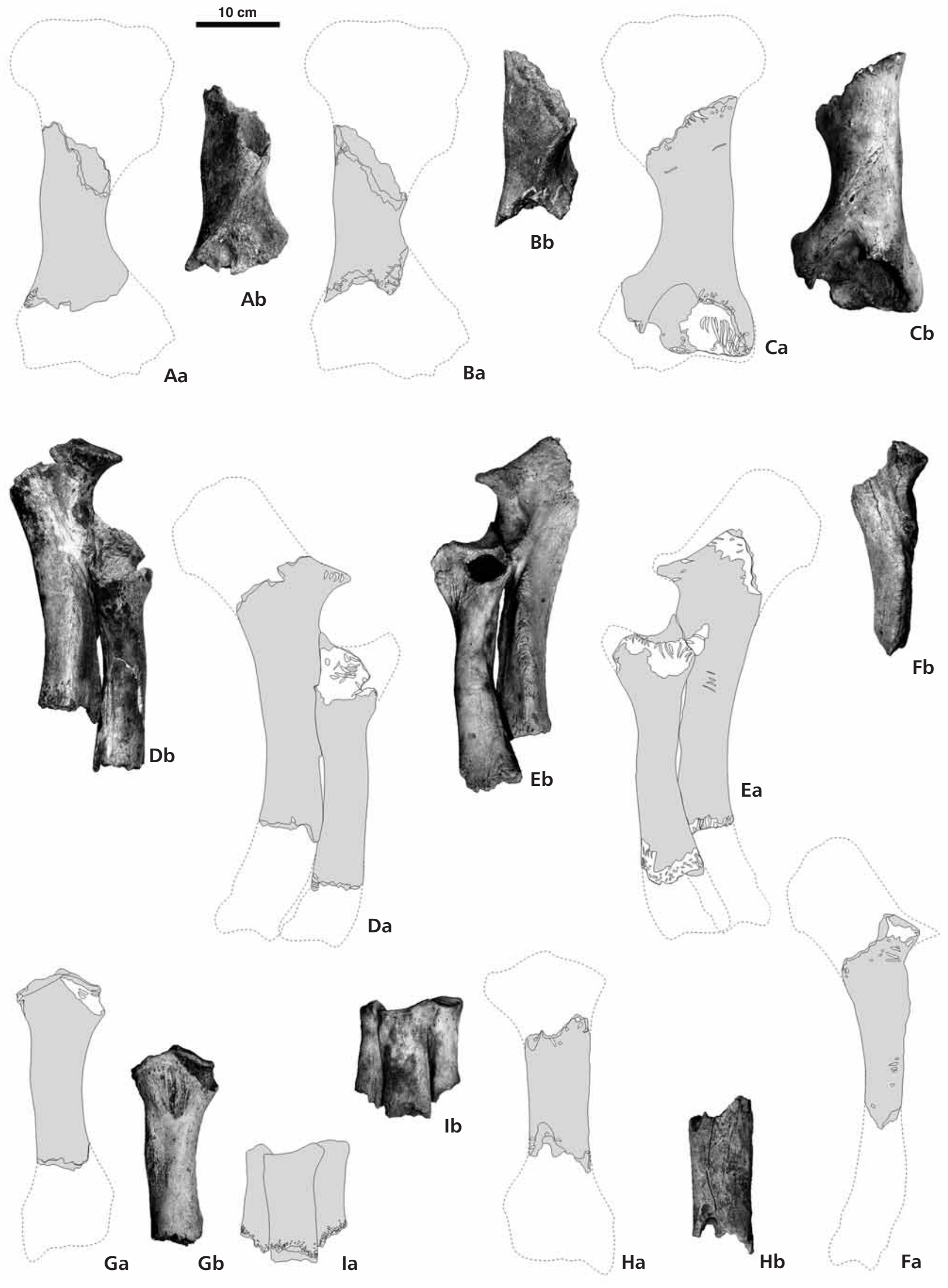


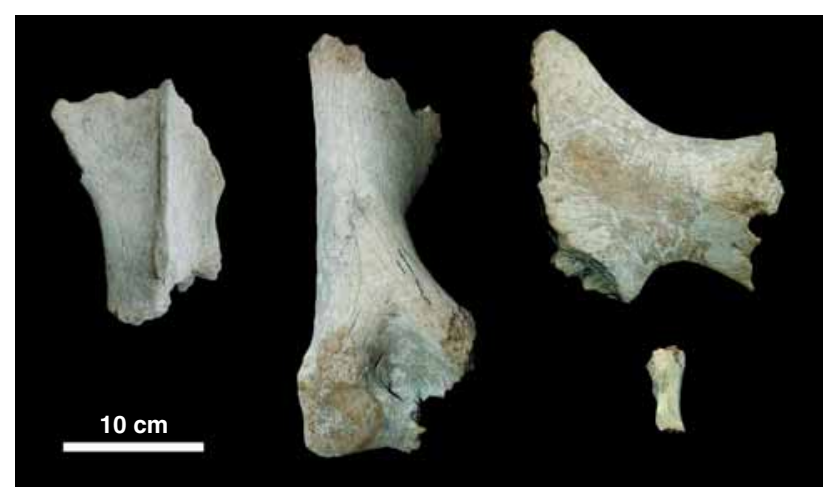

Figure 19. Recent rhino bones that were found inside the Kayanya C. c. crocuta hyena den cave and the Ngorongoro lakeside C. crocuta hyena den cave in eastern Africa. Left: scapula, Kayanya Cave. Middle: humerus, Kayanya Cave. Right top: Pelvis, Kayanya Cave. Right bottom: Ulna of a neonate animal, Ngorongoro Lakeside Cave. The bones are in exactly the same chewed condition as the Upper Pleistocene woolly rhinoceros bones ( $c f$. Figs 17, 18; Sutcliffe coll. BMNH).

ried by the hyenas into their food storage. In the horizontal caves at Tmaň-Axamitova Brána, Tetín-Turská Maštal, and the Hostim-Nad Kačákem Caves, the incomplete cave bear bone preservation (Fig. 20) is exactly the same as that found at the Perick Caves in Germany. The Turská Maštal and Nad Kačákem Caves can be interpreted as the most important cave bear den sites in the Bohemian Karst, at which cave bears sometimes did not survive their hibernation. Such large carcasses were an optimal food resource for the hyenas, especially at the end of the winter/beginning of spring, when fresh food was rare.

It seems that hyenas "cleaned up" the caves periodically, and that they are mainly responsible for the disarticulation and destruction of cave bear skeletons. They even cracked the lower jaws (Fig. 20A), and generally chewed off the joints of long bones (Fig. 20B).

Additional skeletal disarticulations may have been caused by the remains being trampled over by other cave bears, but this would have resulted in much less bone cracking, as has long been believed. As shown in the Perick Caves, the high degree of cave bear bone destruction in cave bear dens is a result of hyena and not cave bear activities ( $c f$. Diedrich $2005 \mathrm{~g}$ ). Frost breakage or sediment compaction might have damaged some bones, but the presence of backflaking, cracked bone pieces that fit together, and bones with chew marks argue against abiotic and non-hyenid bone destruction. The Upper Pleistocene material of the Bohemian horizontal caves was not significantly transported by solifluction or high sediment pressure. In the Middle Pleistocene, especially at the Srbsko-Chlum localities, solifluction and the vertical falling of the material might have caused additional fragmentation of already damaged bones.

\section{Antler collectors}

Antler remains with chewing marks were collected in the Bohemian Karst, but are quite rare in hyena den caves in this region. Most of the red deer antlers were collected at Koněprusy-Chlupáčova Sluj Cave (Eemian to Weichselian age, Fig. 21B). One reindeer antler was found at Hlubočepy-Svatoprokopská Cave (Fig. 21A). The lack of giant deer antlers in the Bohemian Karst hyena den sites indicates the rarity of that animal in this region during the Upper Pleistocene.

C. c. spelaea collected the antlers of all kind of cervids, which were of interest because the hyenas could digest the bone collagen. They were also used as "nibbling bones" in the den sites. Gnawed and chewed antlers from Megaloceros giganteus, Rangifer tarandus, and Cervus elaphus have been found at various hyena den and prey deposit sites in central Europe. The remains of antler bases of $M$. giganteus and $C$. elaphus from the Perick Caves are well figured (Diedrich 2005e, accepted a). In most cases, hyenas left only the "rose" part of the antler. In the Perick Caves and at the open air hyena den site at Bad Wildungen-Biedensteg, typical basal antler remains of the reindeer $R$. tarandus were found (Diedrich accepted $b$ ) that are similar to those from the Hlubočepy-Svatoprokopská Cave.

\section{Hyena cannibalism}

The most incomplete Upper Pleistocene C. c. spelaea remains found in the Bohemian Karst are from the Hostim-Nad Kačákem Cave and the Tetín-Turská Maštal Cave. Tooth and jaw material is mainly present at these sites, whereas postcranial bones are strongly fragmented and less frequent. In Koněprusy Caves-Prošek Dome only a few of such bones show chew marks (Fig. 22A, $\mathrm{B}, \mathrm{D}, \mathrm{G})$, and the abundant bone material from the Srbsko-Chlum-Komín is mostly complete. However, cracked and chewed bones from the skeleton of an adult individual (Fig. 22C, E, F) indicate hyena cannibalism at this prey depot site. In contrast to the degree of bone destruc-

Figure 18. Examples of chewed woolly rhinoceros Coelodonta antiquitatis hind limb and pelvic bones. A - left femur from Koněprusy Caves-Prošek Dome (NMP No. Ra 4193). • B - right femur from Turská Maštal Cave (NMP No. Ra 4278). • C - right tibia from Srbsko-Chlum-Komín (NMP No. Ra 4215). D - articulated right tibia/fibula from Koněprusy Caves-Prošek Dome (NMP No. Ra 4192). • E - left tibia from Turská Maštal Cave (NMP No. Ra 4275). • F - left tibia shaft from Axamitova Brána Cave (NMP No. R 1678). • G - left astragal from Axamitova Brána Cave (NMP No. R 1631). • H - left astragal from Srbsko-Chlum-Komín (NMP No. Ra 3387). • - right pelvic remains (acetabular) from Nad Kačákem Cave (NMP No. R 2311). 
Cajus G. Diedrich \& Karel Žák • Prey deposits and den sites of the Upper Pleistocene hyena
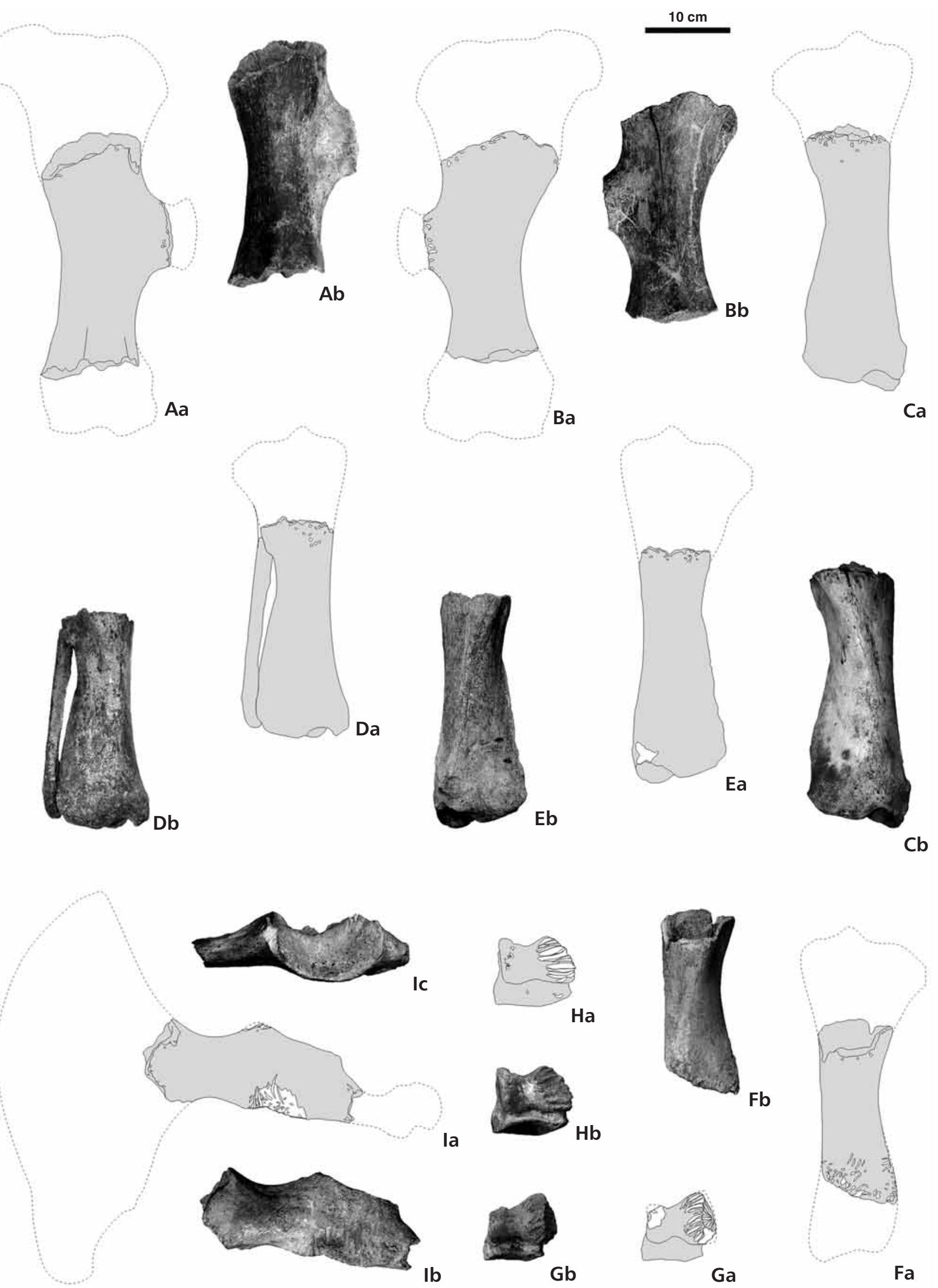

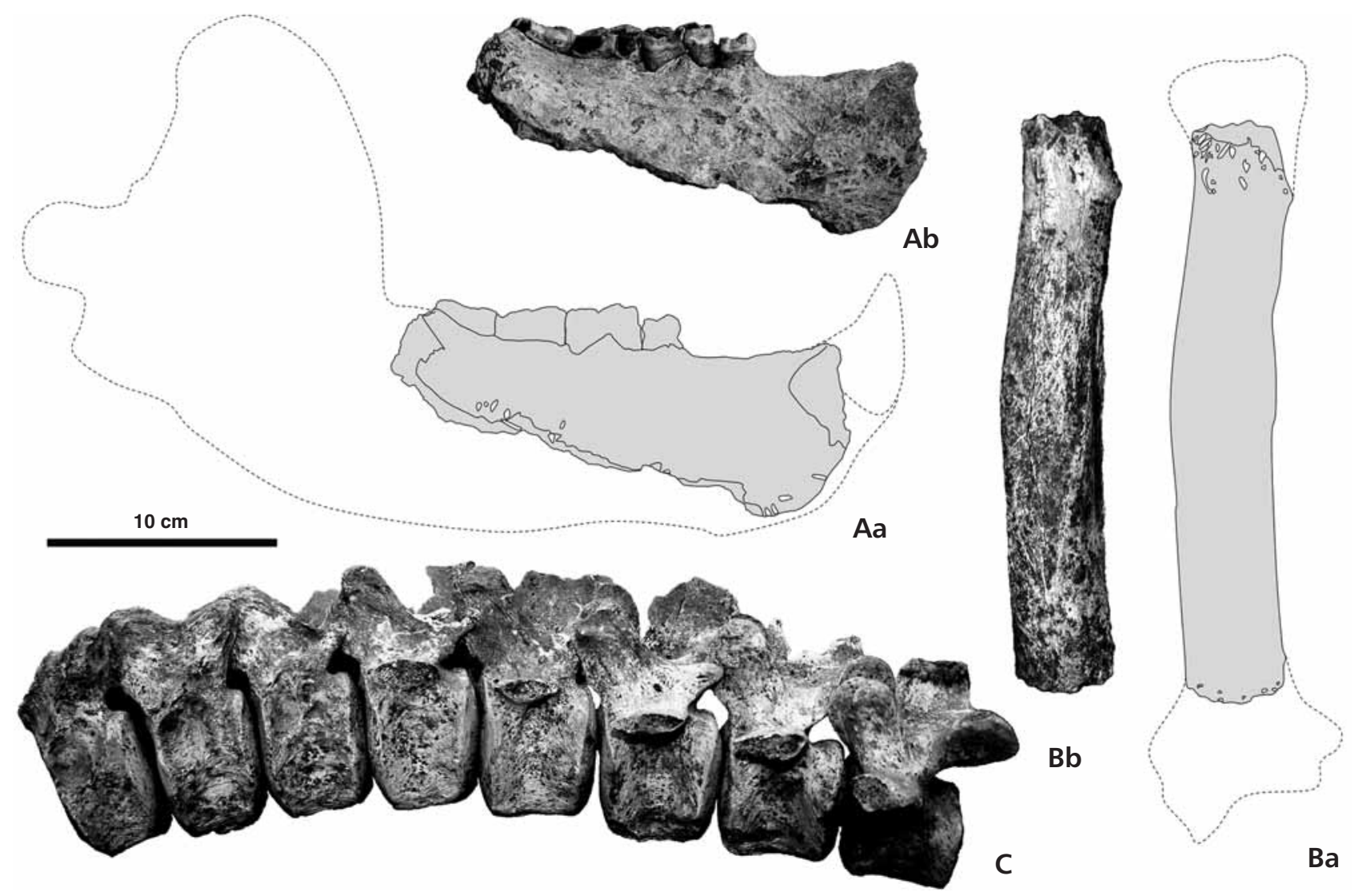

Figure 20. Bone remains of the cave bear Ursus cf. spelaeus Rosenmüller from the hyena den at Nad Kačákem and Turská Maštal Caves. • A - cracked right mandible from Nad Kačákem Cave (NMP No. R 3328). • B - chewed ulna shaft from Turská Maštal Cave (NMP No. Ra 4212). • C - articulated posterior thoracic to last lumbar vertebra column of an adult male cave bear from Nad Kačákem Cave (NMP No. R 3482-3488). The bones indicate cave bear dens and hyena scavenging.

tion typical of hyena feeding activities, none of the C. c. spelaea bones of the skeleton from Prošek Dome (Fig. 5) were destroyed by hyenas. Furthermore, all the incomplete adult and juvenile skeletal remains from the Srbsko-Chlum-Komín site are generally well preserved and were possibly disarticulated by being trampled instead of scavenged.

Cannibalism is very common for the recent hyena Crocuta c. crocuta Erxleben (cf. Frank 1994), as it was for their Pleistocene relatives (Goldfuss) (cf. Diedrich 2005f, 2006c). Recent hyenas leave many bones of juveniles at their den sites (Fig. 23), including cracked longbones. The accumulation of bones and remains of their own species at den sites is also observed in the recent African spotted hyena C. c. crocuta (Cooper 1993, East et al. 1989). Evidence of hyena cannibalism is also present in the Sutcliffe bone collection from hyena cave dens of Tanzania and Kenya (BMNH London). Cracked, chewed and nibbled hyena bones are well figured from the Upper Pleistocene Perick Caves hyena den (Diedrich 2005f). Such cannibalism is the cause of the enrichment of hyena bones, which comprise between 4-23\% of the prey bones at the studied Bohemian cave sites (Fig. 24A-F). These bones make up an average of $12 \%$ of the prey remains, which is comparable to hyena den cave sites in Germany ( $c f$. Diedrich 2005f).

\section{Hyena prey percentages}

Altogether 5,321 identifiable Upper Pleistocene bones from the main caves of the Bohemian Karst were used for the NISP analysis. A detailed analysis of the MNI will not be possible until all the bone material is prepared and re-assembled, which will take years of future work. Many small fragments, which were not included in the statistics, fit into freshly broken bones. The bone assemblages do not really reflect the percentage of hunted or scavenged prey, and is more a result of taphonomy. Large massive woolly rhinoceros bones survived in many cases, but bones of smaller prey are under-represented. More of this material will be found among the bone fragments, especially cervid bones which crack easily.

Though the prey fauna analyses must therefore be viewed critically, it is so far the only way to get an impres- 
sion of the hyena "prey assemblages". In this study no animals smaller than a fox are represented, because we cannot yet be sure they were the prey of Ice Age spotted hyenas. It seems that hyenas hunted or fed on the carcasses of all large Pleistocene mammals. Their main prey in the Bohemian Karst was Equus ferus przewalskii, which is represented by 16 to $51 \%$ of the hyena prey. Its dominance at the Srbsko-Chlum-Komín site is very impressive (Fig. 24A). The largest animal preyed upon by hyenas in the Bohemian Karst was the woolly rhinoceros Coelodonta antiquitatis, the bones and skulls from which were found in all caves. Rhino remains can comprise 25 to $30 \%$ of the prey bone material, as at Koněprusy Caves-Prošek Dome (Fig. 24B) and Tmaň-Axamitova Brána Cave (Fig. 24E). The sites at Koněprusy-Chlupáčova Sluj Cave, Koněprusy Caves-Prošek Dome, and Srbsko-Chlum-Komín were important for the storage of rhino prey remains. Rangifer tarandus comprises 7 to $15 \%$ of the prey, and was therefore another important food source which is documented at four sites: Srbsko-Chlum-Komín, Koněprusy Caves-Prošek Dome, Tetín-Turská Maštal and Hostim-Nad Kačákem. At the other caves reindeers are much less represented. The steppe bison Bison priscus comprises only 1 to $6 \%$ of the prey fauna at the studied caves. Perhaps, in common with the mammoths (e.g. Mammuthus primigenius), these bisons were not abundant in the hilly landscape of the Bohemian Karst. The nearly complete absence of $M$. primigenius as typical prey on which hyenas scavenged in flatland regions (Diedrich 2005c) seems to be a result of the specific topography. Mammoths are nearly absent in the hilly region of the Bohemian Karst (known finds are mostly along rivers). Only a few mammoth remains are available from the Hlubočepy-Svatoprokopská Cave (Fig. 24F); they suggest possible contact with the Vltava River valley, in which larger animals could seasonally move more easily. This topographic situation is similar to the Sauerland Caves and hyena den sites (Diedrich 2005a). Mammoth remains from Turská Maštal Cave (some long bones, jaw and vertebrae material) have no chew or hyena destruction marks, and are preserved differently than the bones from the hyena den period. Cervus elaphus comprises up to $3 \%$ of the remains at the studied caves, and is absent in some bone assemblages. Megaloceros giganteus is quite rare in the bone material and only represented at two cave sites: Hlubočepy-Svatoprokopská Cave and Koněprusy Caves-Prošek Dome. In the latter, the bones are very cracked and difficult to identify. The Bohemian alpine fauna including Rupricapra rupricapra and Capra ibex is typical for this region and is absent in some places, like the northern German Sauerland hyena den sites (Diedrich 2005f). Because of their fragility, they are represent less then $3 \%$ of the prey at the Bohemian Karst hyena den sites. They are more abundant only at Hostim-Nad Kačákem, which could reflect mixed material from the Magdalenian horizon. In the Upper Pleistocene there seems

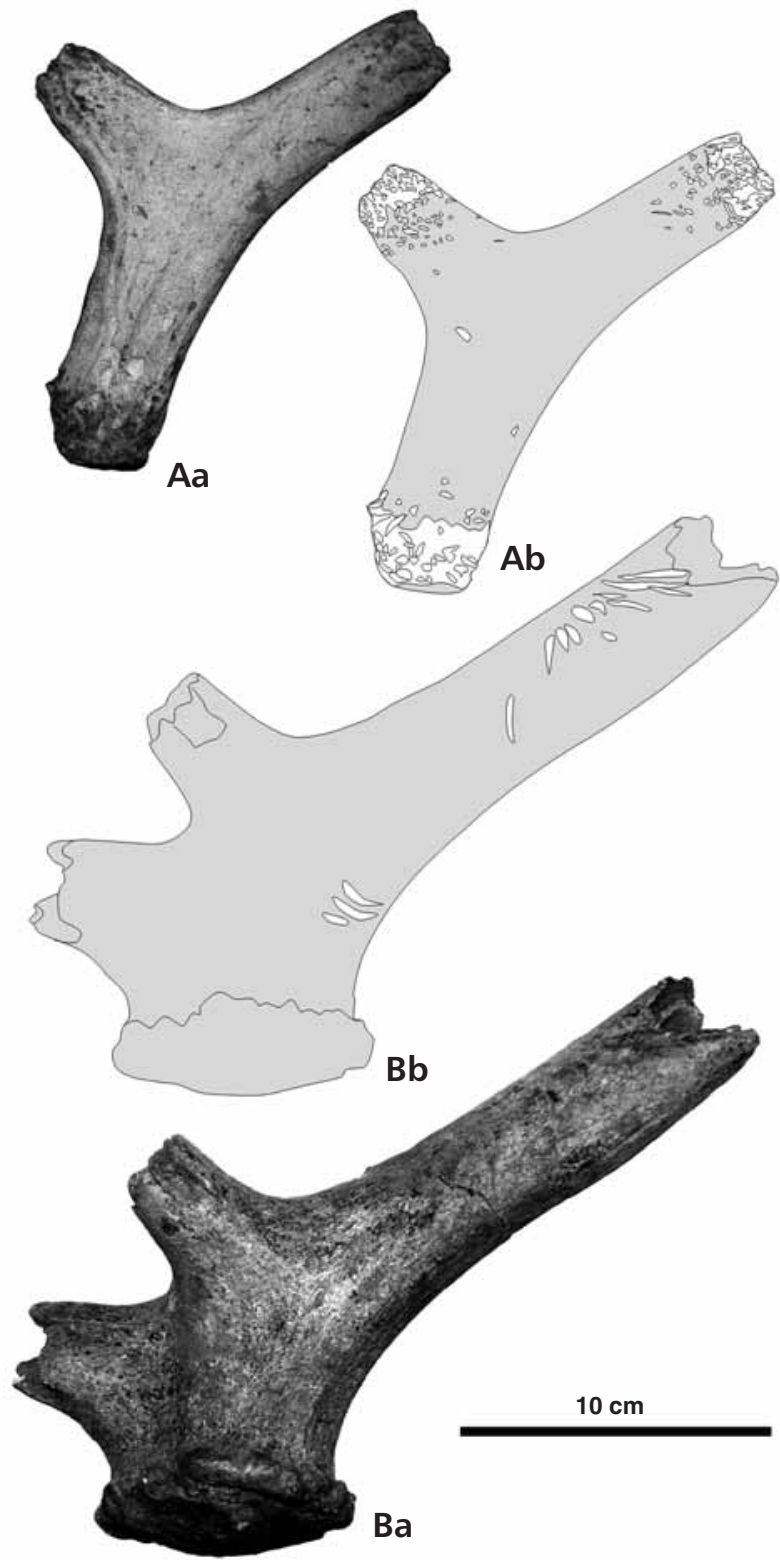

Figure 21. Discarded cervid antlers. Hyenas brought antlers into their dens, where they left only the basal part. $-\mathrm{A}$ - right antler base of $R$. $t a$ randus from the hyena den Hlubočepy-Svatoprokopská Cave (NMP No. $\mathrm{R}$ 2370). - B - right antler base of C. elaphus from the hyena den Chlupáčova Sluj Cave (NMP No. R 2889). All inner view. a - photo, b redrawing.

to be a specialisation on cave bear carcass feeding in cave-rich hilly areas, including the Bohemian sites described here (Fig. 24C-F). The high proportion of the cave bear remains ( 25 to $43 \%$ ) at four different Bohemian caves does not reflect this animal's percentage in the prey. In most cases, only fragments and bones with bite marks were used for the statistical analysis. For the prey analysis it is sometimes difficult to distinguish non-scavenged cave bear bone material from the scavenged one, especially in the case of cranial material, and free teeth finds (Fig. 20A). Signs of 


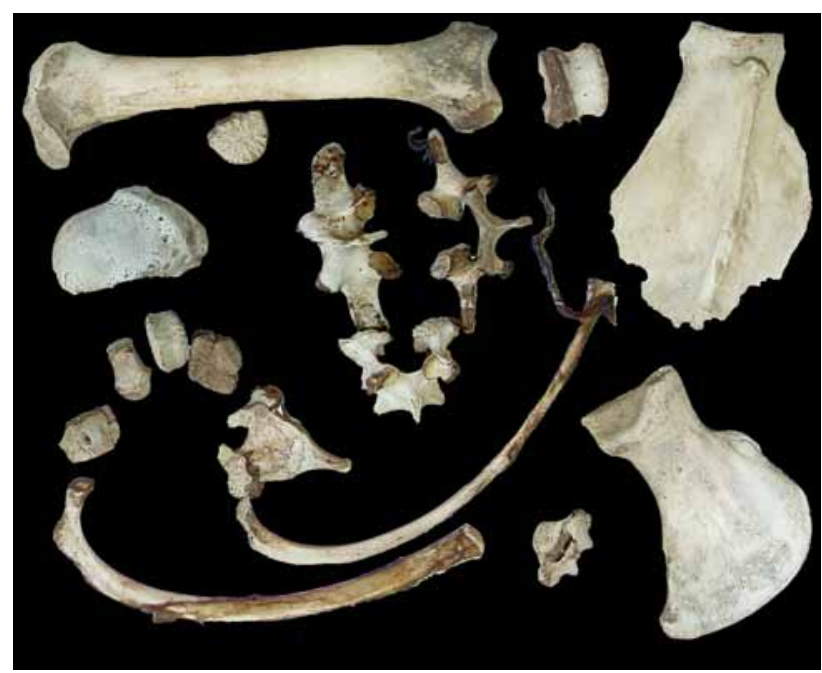

Figure 23. Juvenile remains from the recent African spotted hyena Crocuta crocuta crocuta Erxleben, which were found in front of the Kajiado 46 Mile hyena cave den (Sutcliffe coll., BMNHL).

chewing or cracking can be observed more easily on the postcranial bones. Therefore, the percentage of the cave bear as prey might really be less than is indicated in the diagrams of Fig. 24. Finally the carnivores Panthera leo spelaea, Canis lupus and Gulo gulo are also represented in the prey fauna. It is not clear whether the wolverines are hyena prey remains, or simply remains of individuals that also periodically used the caves as dens. The percentage of hyenas that were preyed upon was discussed in the section on hyena cannibalism. The faunal analyses (Fig. 24C-F) distinguish between two main den types with distinct taphonomic records: the hyena prey depots, and the hyena and cave bear dens. A large amount of $U$. cf. spelaeus bones are present at mixed hyena and cave bear dens (Fig. 24C-F). At hyena-only den sites or prey depot, cave bear remains are absent or very rare (Fig. 24A-B).

Distinguishing between hyena and hominid-influenced bone accumulations in the Bohemian Karst caves is possible at some sites, based on a lack of artefacts, cutting marks or burned bones. The Srbsko-Chlum-Komín locality, which is the most important hyena prey depot site, has no evidence of Paleolithic influence, and seems to be one of the most definitive hyena prey depot sites in Europe.

In contrast, Nad Kačákem Cave, Turská Maštal Cave, and Axamitova Brána Cave are influenced by Magdalenian (and earlier) humans. However, based on stratigraphy, it seems that the caves were used by humans after the hyena/cave bear use. Hyenas seem to have become extinct in Bohemia and central Europe at about 24000 BP, i.e., before the Magdalenian period, which could be the reason for their rarity in cave art (Leroi-Gourhan 1965, Lorblanchet 1995, Diedrich 2005f).

The main criterion for distinguishing hyena and hominid bone sites is a high percentage of carnivore material, which should be more then 20\% for hyena caves (Brugal et al. 1997, Fosse 1999, Pickering 2002). The remains at the Srbsko-Chlum-Komín site contain $25.1 \%$ carnivores, but no cave bears. The Koněprusy Caves-Prošek Dome cave site has a similar carnivore percentage (18\%). Both seem to be non-human influenced bone accumulations. Tetín-Turská Maštal has 25\% carnivores, but includes a large amount of cave bear material. The high proportion of $44 \%$ carnivores at Axamitova Brána and 53.1\% at Praha-Hlubočepy is a result of cave bear presence. The remains at the $\mathrm{Nad}$ Kačákem Cave contain only $13 \%$ carnivores, which might reflect the mixing of Magdalenian bones with older remains from hyena/cave bear den periods.

The argument of Fosse (1999), that more cranial than postcranial elements are present in hyena dens, is consistent only for the remains found in the horizontal caves (hyena dens) such as Tetín-Turská Maštal Cave and Nad Kačákem Cave. In the approximately vertical SrbskoChlum-Komín cave, the postcranial material is mostly well preserved and much more dominant. The same situation applies to Koněprusy Cave-Prošek Dome, but this fact results from articulated skeletal remains that were not scavenged. In vertical caves, which seem to have been used as hyena prey deposits, articulated skeletons and postcranial bones of $C$. c. spelaea are more frequent. In the den sites of horizontal caves, hyena cannibalism and other destructive activities left mainly tooth and other cranial material, such as at Tetín-Turská Maštal Cave and Nad Kačákem Cave. Even in some open air den sites, such as Bad Widlungen Biedensteg, cranial bones outnumber the postcranial ones (Diedrich 2006c).

An abundance of prey limb bones are present in all Bohemian caves used by hyenas. The metapods and phalangae of horses and bisons are mostly non-chewed. The femora and humeri in contrast lack their joints in many cases. The large amount of articulated horse legs found at Srbsko-Chlum-Komín is very remarkable.

\section{Den marking by fecal pellets}

Aside from the many hyena bones and other skeletal remains, coprolite material from the Ice Age carnivores must also have been quite common at the Bohemian Karst cave localities described here. Only a few fecal pellets were found in the old collections, mostly among the bone fragments. Coprolites were only collected by J. Petrbok and J. Beneš, but were not identified or labelled as such. About 60 coprolites were rediscovered in the material from the cave sites Kobyla-Chlupáčova Sluj Cave (6 pellets), Koněprusy Caves-Prošek Dome (50 pellets), SrbskoChlum-Komín (3 pellets), and Tetín-Turská Maštal Cave ( 2 pellets). Sediment sieving performed by the present authors during the clearing activities of the Speleoclub at the 


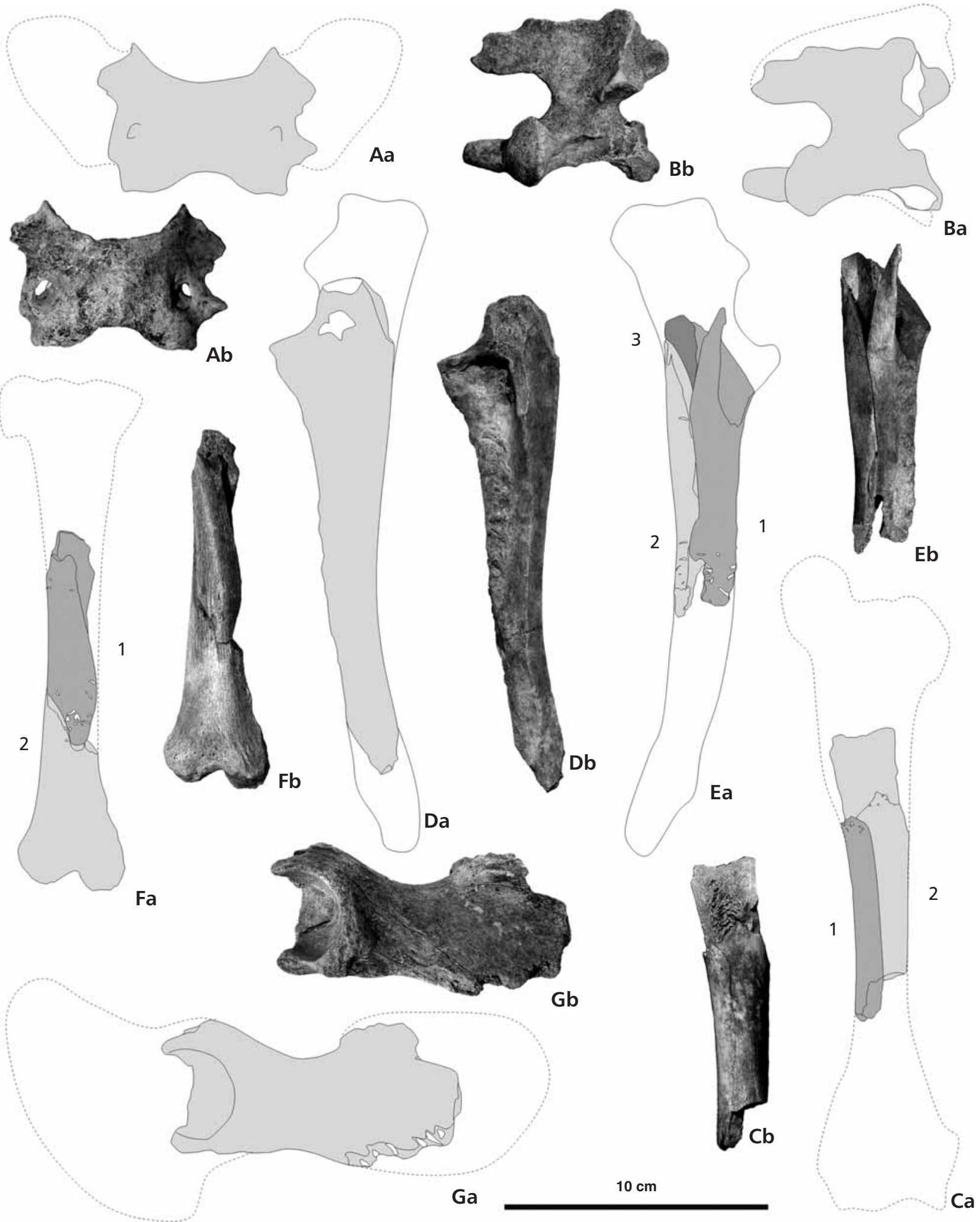

Figure 22. Cracked and chewed postcranial bones of adult Crocuta crocuta spelaea (Goldfuss) individuals from the Bohemian Karst. • A, B, D, and G from Koněprusy Caves-Prošek Dome. $\bullet$ C, E, and F from Srbsko-Chlum-Komín (white $=$ bite marks). a - redrawing, $b-$ photo. $\bullet$ A - chewed atlas $($ NMP No. Ra 4048), dorsal. • B - chewed axes (NMP No. Ra 4050), lateral. • C - right humerus shaft cracked in two pieces (NMP No. Ra 4138), caudal. $\bullet$ D chewed left ulna (NMP No. Ra 4045), lateral. $\bullet$ E - right ulna cracked in three pieces (NMP No. Ra 4136), lateral. $\bullet \mathrm{F}$ - right cracked tibia cracked in two pieces (NMP No. Ra 4141). $\bullet \mathrm{G}$ - right chewed pelvis fragment (NMP No. Ra 4047), lateral. 
Srbsko-Chlum-Komín site in 2005/6 resulted in the recovery of six more pellets (Fig. 25J, N). Sediment samples from Srbsko-Chlum-Komín consist of very high proportions of small coprolite fragments, which seems to be the result of trampling and destruction by the hyenas themselves. Similar small and abundant coprolite fragments were found in the sediment that was stuck to a strongly chewed woolly rhinoceros femur shaft at the hyena den in Turská Maštal Cave (Fig. 18B). This indicates an originally large amount of fecal pellets in the of the hyena den horizon at this site. Small bone fragments of large prey are often contained within the phosphate-cemented hyena excrements found at the sites Koněprusy Caves-Prošek Dome, Srbsko-Chlum-Komín, and Tetín-Turská Maštal Cave (Fig. $25 \mathrm{G}-\mathrm{I}, \mathrm{N})$. Many more pellets must have originally been present at all hyena den sites described here.

Recent spotted hyenas use fecal pellets (Fig. 26) to mark their territory and especially their den sites (Bearder \& Randall 1978). The Ice Age spotted hyenas must have done the same. There are well documented examples of this at the German open air sites Bad Wildungen-Biedensteg (Diedrich 2006c) and Morschen-Konnefeld (Keller \& Försterling 2002), as well as in France (Fosse 1999). The hyena pellets found at these sites were important markers for defining hyena activity zones or den sites (Fosse 1999). Large amounts of coprolites were also found among the bones at a hyena prey depot site in southwestern France (cf. Fosse et al. 1998, Fosse 1999). The number of the pellets from the Koněprusy Caves-Prošek Dome seems to be representative compared to the total number of bone finds. Some sites, such as Turská Maštal, contain no more material for further excavations. In contrast, new excavations at the Srbsko-Chlum-Komín and the Nad Kačákem Caves could produce more pellet material. It will be important to map and collect the pellets during any future field research. Also the percentages of pellet fragments in the sediment will be of importance for discerning frequented hyena dens, where pellets were trampled and destroyed by the hyenas themselves.

\section{The use of caves by other animals}

The sites of hyena bone deposits were also often used in the Upper Pleistocene as dens or food storage of common foxes Vulpes vulpes, which resulted in the accumulation of bones from smaller animals such as the snow hare (Lepus timidus) or willow grouse (Lagopus lagopus). The snow owl Nyctea scandiaca or other owls must have also used caves such as the Srbsko-Chlum-Komín or Koněprusy Caves-Prošek Dome. In the latter, some snow owl bones were found, while the remains of thousands of micromammals contained in pellets provide further, indirect evidence. Marmots (Marmota marmota) also used caves as their dens at the end of the Pleistocene, which can be de- monstrated for the Srbsko-Chlum-Komín, Nad Kačákem, and Turská Maštal Caves.

The common fox (Vulpes vulpes) and badger (Meles meles) moved into caves or sinkholes during the Holocene. They were responsible for the accumulations of Holocene animal bones such as roe deer, hares, wild pigs and even modern house animals. Skeletons of the Holocene brown bear Ursus arctos and the wolf Canis lupus were found at Koněprusy Caves-Prošek Dome. Finds of Holocene brown bears are also known from other caves in the area (such as Menglerova Cave, Beneš 1983).

\section{Conclusions}

During the Middle to Upper Pleistocene, several vertical caves in the Bohemian Karst became filled with hyena prey bone remains, mainly where vertical cavities are connected to larger horizontal caves, such as the Koněprusy Caves and the Srbské Caves-Netopýří Caves at Chlum near Srbsko. Several thousands of bones resulting from imported prey careasses were accumulated by numerous generations of hyena clans. The most important cave localities are Koněprusy-Kobyla-Chlupáčova Sluj Cave, Koněprusy Caves-Prošek Dome, Srbsko-Chlum-Komín, and Srbsko-Chlum-Sluj II-IV. The vertical chimneys were accessible at various times ranging from the Early Middle to Upper Pleistocene. Middle Pleistocene prey deposits must have been moved by solifluction and/or sediment collapses, which caused some bone material to fall about $40 \mathrm{~m}$ below the surface. Upper Pleistocene prey deposits seem to be redeposited to a lesser degree, but are considerably bioturbated by the activities of hyenas and other animals. The large amount of hyena den and prey deposit sites in the Bohemian Karst indicate the occupation by clans of $P$. brevirostris (Middle Pleistocene) and C. c. spelaea (Upper Pleistocene) over hundreds of thousands of years. The hyena clans all had similar paleoecological habits: prey storage in karst depressions and caves and in mud pits along rivers, but also in bringing food to the juveniles that grew up in and around the den sites.

Two different taphonomical situations can be distinguished for the Upper Pleistocene Bohemian cave localities, depending on cave type and accessibility: vertical caves, and horizontal caves. To the first cave type belongs the Srbsko-Chlum-Komín site, Koněprusy Caves-Prošek Dome (which has a vertical chimney above the southern part of the dome), and Koněprusy-Kobyla-Chlupáčova Sluj Cave. Hyenas temporarily had direct access into these caves through the narrow chimneys. They used these places for protecting their juveniles and for food storage. They also scavenged in the den sites on the imported prey animals. The principal prey in the Bohemian Karst during the Upper Pleistocene was the horse Equus ferus przewalskii, and the woolly rhi- 
A

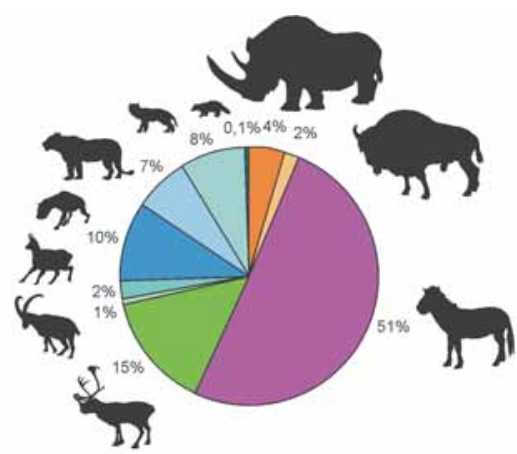

C

E

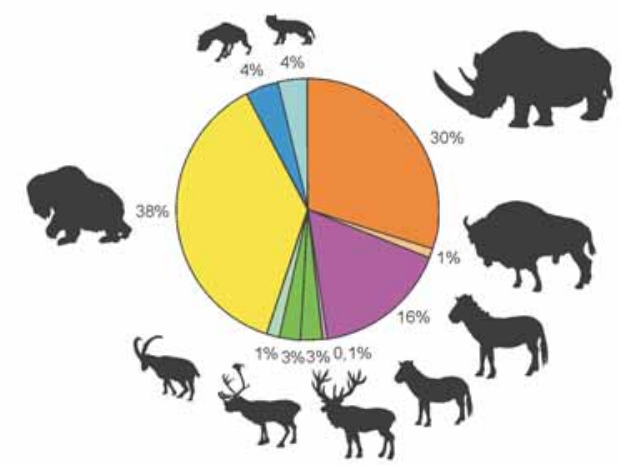

B

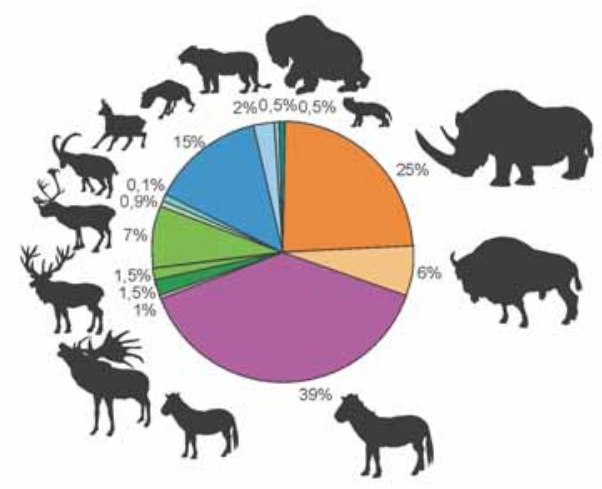

D

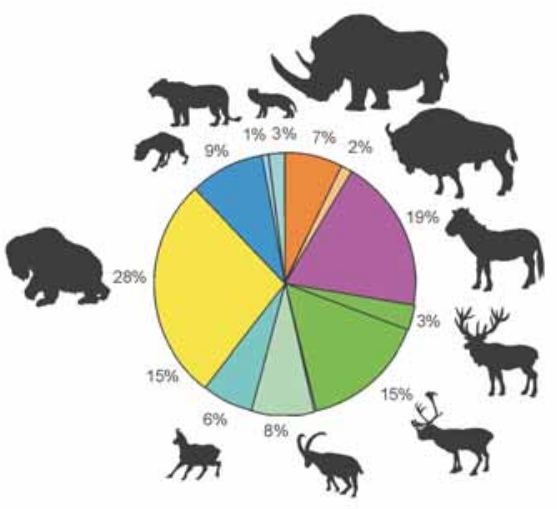

$\mathbf{F}$

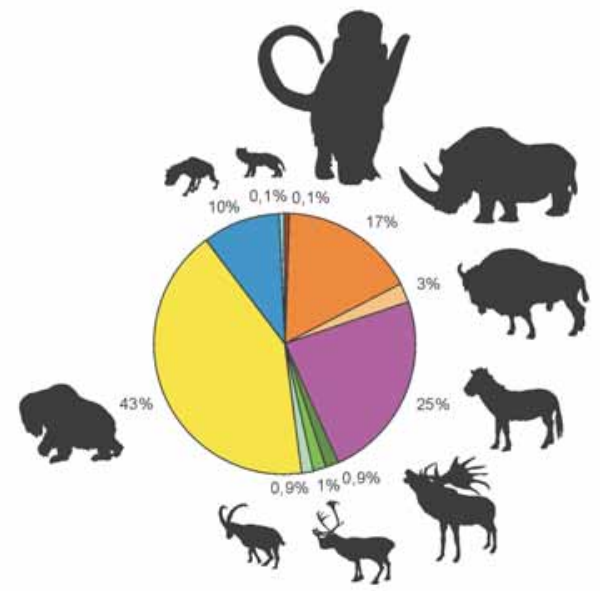

Rupricapra rupricapra

Ursus spelaeus

Crocuta crocuta spelaea
Panthera leo spelaea

Canis lupus

Gulo gulo

Bison priscus

\section{.}

Equus hydruntinus

Megaloceros giganteus
Rangifer tarandus

Capra ibex

Figure 24. Proportions of prey remains (estimated for the NISP) from the den and prey deposit sites of the hyena Crocuta crocuta spelaea (Goldfuss) in the Bohemian Karst. • A - Srbsko-Chlum-Komín site (NISP = 3,569 bones). The large amount of horses, including the skeletal remains of neonate to adult animals, is unique. Steppe lions are represented by two skeletons, and hyenas by five partial skeletal remains. $\bullet$ B - Koněprusy Caves-Prošek Dome (NISP $=711$ bones). Large amounts of the hyena remains are typical of hyena den sites. The dominant prey is the horse and the woolly rhinoceros. In this hilly region, alpine animals such as $C$. ibex and $R$. rupricapra are also present in the prey remains, whereas the giant deer and the Ice Age donkey are quite rare. $\bullet \mathrm{C}$ - Tetín-Turská Maštal Cave (NISP $=357$ bones). The high proportions of hyenas indicate a frequented den site, in which hyenas also scavenged and fed on dead cave bears that did not survive hibernation. Cave bears were scavenged here by hyenas that left many chewed and cracked bones. $\bullet$ D - Hostim-Nad Kačákem Cave (NISP = 423 bones). The high percentages of $R$. rupricapra and C. ibex, and even R. tarandus, could be the result of bone

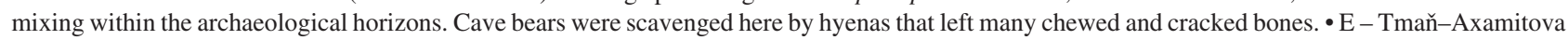
Brána (NISP $=221$ bones). Hyena and cave bear den, and repeatedly used archaeological site. Cave bears hibernated here and were also scavenged by hyenas that left many chewed and cracked bones. $\bullet F-$ Praha-Hlubočepy-Svatoprokopská Cave (NISP $=221$ bones). Hyena and cave bear den. The mammoth prey remains could indicate their former presence in the nearby Vltava River valley. 


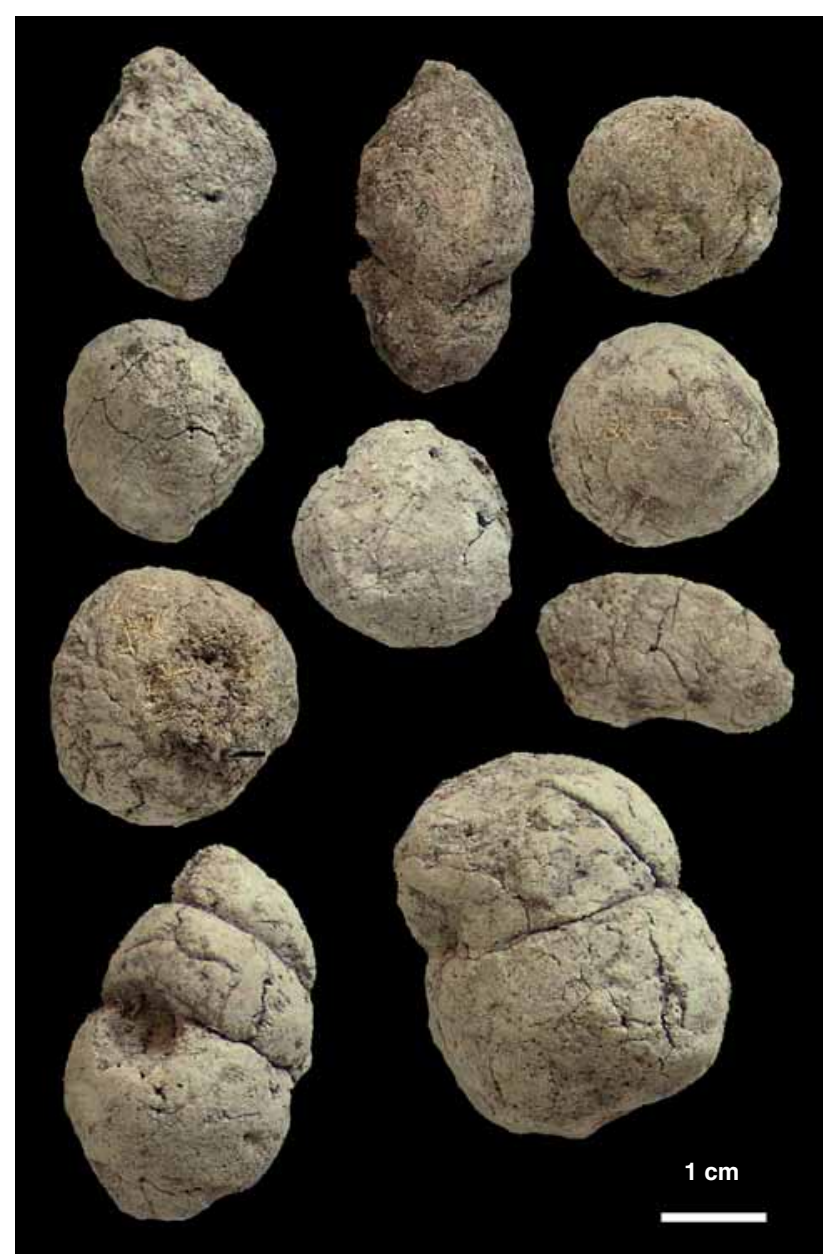

Figure 26. Fecal pellets from the recent African spotted hyena Crocuta crocuta (Erxleben). These phosphatic droplets were found inside the Kayanya Cave hyena den (Sutcliffe coll., BMNHL). The consistency and shapes of recent and fossil coprolites of spotted hyenas are identical.

noceros Coelodonta antiquitatis. For the latter, hyena feeding strategies were clearly indicated on cranial and postcranial bones. Additionally, hyenas fed on the steppe bison Bison priscus, the reindeer Rangifer tarandus, the red deer Cervus elaphus, the giant deer Megaloceros giganteus, the Ice Age donkey Equus hydruntinus, and the Bohemian alpine fauna including Rupricapra rupricapra and the ibex Capra ibex. Even carnivores such as the cave bear Ursus spelaeus, the steppe lion Panthera leo spelaea, the wolf Canis lupus, and possibly the wolverine Gulo gulo were rarely scavenged. Conflicts between hyenas and lions probably occurred, which resulted in the presence of complete steppe lion skeletons in hyena den caves such as Srbsko-Chlum-Komín. The large accumulation of macrobones were caused the feeding habits of C. c. spelaea, who were bringing food to the cubs in the dens or were hiding prey in caves or open-air mud pits. Massive bones of the woolly rhinoceros, and the massive leg bones of other large animals, such as horses, were not destroyed or eaten com- pletely. Older carcass remains were eventually discarded, resulting in an enormous accumulation of bones (e.g., more then 3,500 in the Srbsko-Chlum-Komín). Hyena cannibalism resulted in the accumulation of a large amount of hyena bones among the remains of other prey. These vertical caves were also used during the Upper Pleistocene, possibly by wolverines ( $G$. gulo), but surely by common foxes ( $V$. vulpes), badgers, (M. meles) marmots (M. marmota) and owls ( $N$. scandiaca), which left their own bones among those of smaller animals, such as micromammals, fish, reptiles, and frogs. The most undamaged prey remains were found in the vertical caves.

Some horizontal caves of the Bohemian Karst were used by U. spelaeus for hibernation, but hyenas and other animals also used them as dens. Hyenas and young cubs had easy access to the horizontal caves, where bones are found in highly fragmented conditions. Nibbling sticks are very typical at such localities, while coprolites offer evidence for defining the den sites. Middle Paleolithic people, and later, more numerous Magdalenian, Neolithic, Bronze Age and younger Iron Age people also used these caves. They were also used during the Holocene by wolves, brown bears, common foxes, and badgers. Such multi-used sites with rich bone accumulations in the Bohemian Karst include the Tmaň-Axamitova Brána Cave, Tetín-Turská Maštal Cave, Hostim-Nad Kačákem Cave, Praha-Hlubočepy-Svatoprokopská Cave, and Řeporyje-Kalvárie Cave.

\section{Acknowledgements}

We would like to thank V. Cílek from the Academy of Sciences (Institute of Geology) for historical information about J. Petrbok, and for support for this project. The localities at Koněprusy-Prošek Dome, Dědkova Díra, and the present-day Petrbokova Sluj Cave were visited with the permission of A. Komaško. J. Kovanda was very helpful with many questions about the collecting activities and the history of J. Petrbok. Access to the collection of bone material at the Museum of the Bohemian Karst in Beroun was made possible by I. Jančaříková, and the head of the Natural History Museum in Prague, J. Litochleb. The head of the Department of Palaeontology of the National Museum in Prague K. Zágoršek supported our work in the large Pleistocene collection. Information on the human remains was given by the anthropologists P. Veleminský and V. Kuželka of the National Museum in Prague. The Prague Speleological Club, especially K. Ryšánek, made cave trips at Srbsko-Chlum possible. The curator of the Pleistocene collection in the British Museum of Natural History in London, A. Currant, was very helpful in the study of the recent African spotted hyena material of the Sutcliffe Collection. He also gave access to Pleistocene hyena material of Reynolds at the Taunton Museum in Summerset, and the Pleistocene hyena material from the Perick Caves. Finally, we thank M. Diedrichová for the rediscovery of some important hyena bones and coprolites at the Srbsko-Chlum-Komín site in 2005/6. The study was supported by the research program AV0Z30130516 of the Institute of 


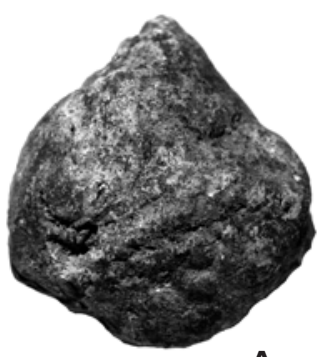

A
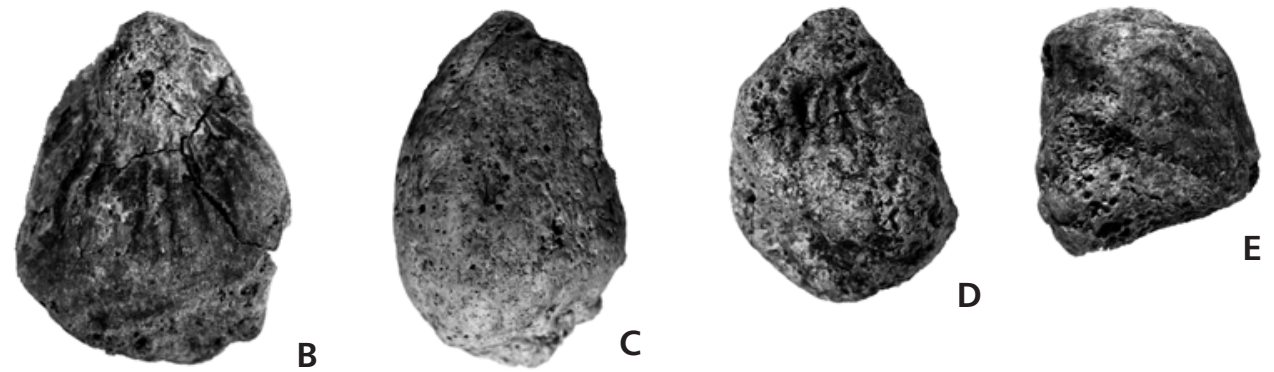

\section{B}
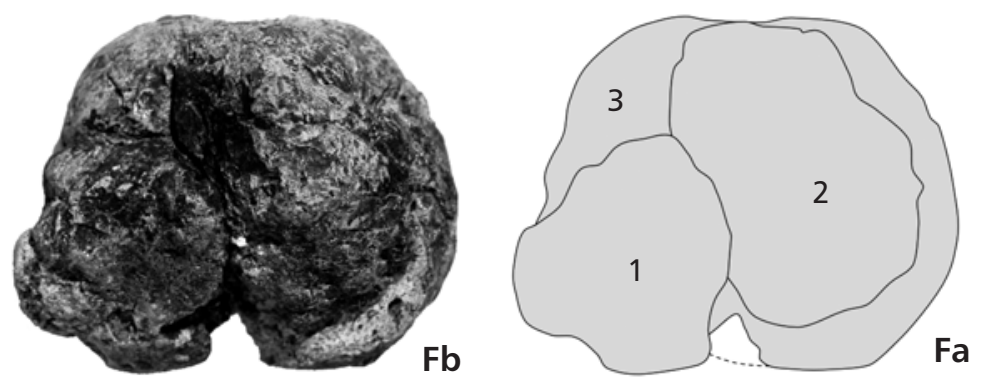

Bone
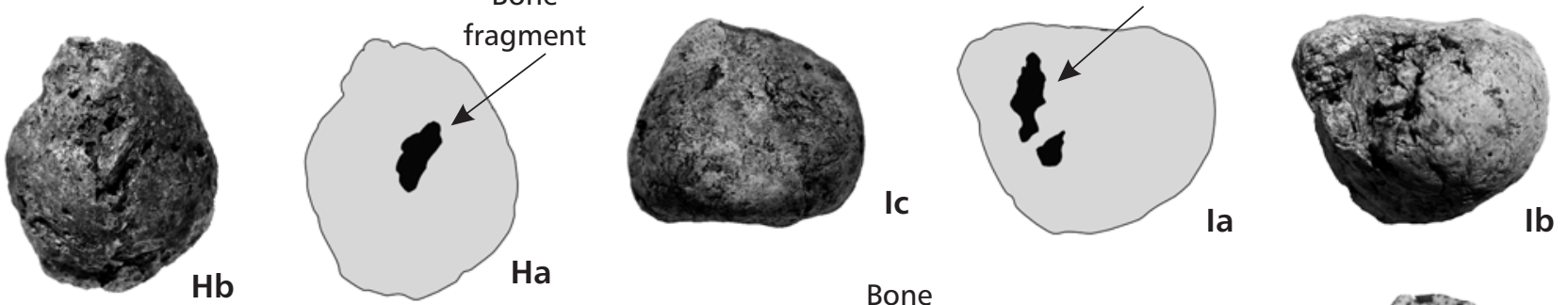

$\mathrm{Hb}$
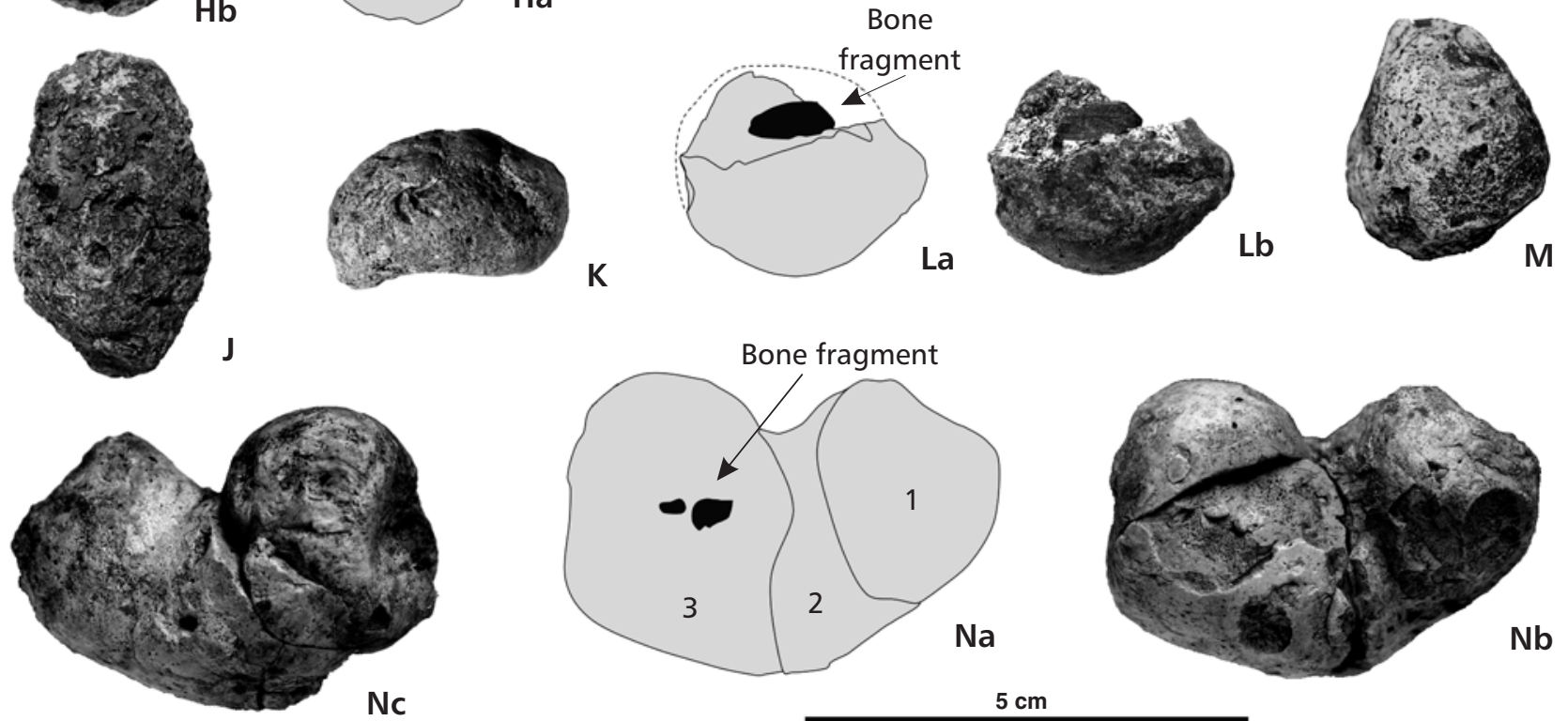

Figure 25. Coprolites of Crocuta crocuta spelaea (Goldfuss) from the hyena dens of the Bohemian Karst (Czech Republic). a - redrawing (bone fragments in black), b - photo. • A-I - Koněprusy Caves-Prošek Dome. • J-L, and N-Srbsko-Chlum-Komín. • M - Tetín-Turská Maštal. • A - single drop shaped pellet (No. Ra 4071). B - irregular shaped pellet with radial wrinkles, which was attached to other pellets (No. Ra 4069). $\bullet$ C - long-oval pellet (No. Ra 4073). D - irregular pellet with radial wrinkles, which was attached to other pellets (No. Ra 4076). $\bullet$ - irregular pellet (No. Ra 4067). $\bullet$ F - three (1-3) articulated pellets (No. Ra 4068). $\bullet \mathrm{G}$ - round pellet with bone fragment (No. Ra 4089). • H - oval pellet with bone fragment (No. Ra 4072). • I - drop shaped pellet containing bone fragments, which was attached to other pellets (No. Ra 4066). $\bullet J-$ long-oval pellet (No. Ra 4130). $\bullet \mathrm{K}-$ single flat pellet, which was attached to other pellets (No. Ra 4131). $\bullet \mathrm{L}-$ single flat pellet, which was attached to other pellets containing a bone fragment (No. Ra 4032). $• \mathrm{M}$ - irregular pellet, which was attached to other pellets (No. Ra 4270). $\bullet \mathrm{N}-$ three (1-3) articulated pellets (No. Ra 4281). 
Geology, Academy of Sciences of the Czech Republic. The comments of two anonymous reviewers significantly improved the manuscript and are highly appreciated. The authors are grateful to J. Norris for language correction of the manuscript.

\section{References}

Avery, G., Avery, D.M., Braine, S. \& Loutit, R. 1984. Bone accumulation by hyenas and jackals a taphonomic study. South African Journal of Science 80, 186-187.

BABOR, J.F. 1904. Diluviální člověk. 35 pp. Zeměpisná knihovna, Praha.

BAryshnikov, G.F. \& Boeskorov, G. 2001. The Pleistocene cave lion, Panthera spelaea (Carnivora, Felidae) from Yakutia, Russia. Cranium 18, 7-24.

BAtemAn, G. 1987. Raubtiere der Welt. 159 pp. Orbis-Verlag, München.

BEARDER, S.K. \& RANDALL, R.M. 1978. The use of fecal marking sites by spotted hyaenas and civets. Carnivore 1, 32-48.

BeHRENSMEYER, A.K. \& BoAZ, D. 1980. The recent bones of Amboseli Park Kenya in relation to east African paleoecology, 72-92. In BeHRENSMEYER, A.K. \& HiLl, A.P. (eds) Fossils in the making: vertebrate taphonomy and paleoecology. University of Chicago Press, Chicago.

BENEŠ, J. 1970. Pleistocenní savci z Chlumu u Srbska (Čechy). Časopis Národního muzea, Oddíl přirodovědný 137(3/4), 17-26.

BENEŠ, J. 1983. Medvědi z Menglerovy jeskyně. Český kras 8 , 41-49.

Beneš, J. \& Kovanic, P. 1964. Patologický nález na kosti soba. C̆asopis pro mineralogii a geologii 8(2), 220.

BRAIN, C.K. 1980. Some criteria for the recognition of bone collecting agencies in African caves. 107-130. In BEHRENSMEYER, A.K. \& HILL, A.P. (eds) Fossils in the making: vertebrate taphonomy and paleoecology. University of Chicago Press, Chicago.

Brugal, J.P., Fosse, P. \& Guadeli, J.P. 1997. Comparative study of bone assemblages made by recent and Plio-Pleistocene Hyaenids (Hyena, Crocuta), 158-187. In HANnUS, L.A., Rossum, L. \& Winham, R.P. (eds) Proceedings of the 1993 Bone Modification conference, Hot Springs, South Dakota, Occasional Publication 1(1). Arachaeological Laboratory, Augustana Collegue, Sioux Falls.

Cardoso, J.L. 1993. La Hyène des "Oubliettes" de Gargas, Crocuta crocuta spelaea (Mammalia, Carnivora). Bulletin de la Musée Naturelle et Histoire Naturelle, Section C, Science de la Terre, Paléontologie, Géologie, et Minéralogie 4(15), 79-104.

CíleK, V. 1993. K otázce aktivního toku v Prokopské jeskyni. Speleo 11, 18-19.

CíleK, V. 1995. Podzemni Praha. 58 pp. Knihovna České speleologické společnosti 27. Česká speleologická společnost a nakladatelství Zlatý Kůň, Praha.

CoOPER, S.M. 1993. Denning behavior of spotted hyaenas (Crocuta crocuta) in Botswana. African Journal of Ecology 31, 178-180.

CRUZ-URIBE, K. 1991. Distinguishing hyena from hominid bone accumulations. Journal of Field Archaeology 18, 467-486.

CuRrant, A. 2004. The Quaternary mammal collections at the
Somerset County Museum, Taunton, 101-108. In SCHREve, D.C. (ed.) The Quaternary mammals of southern \& eastern England. Quaternary Research Association, Field guide.

Cuvier, G. 1805. Sur les ossements fossiles des Hyènes. Annales de Musée Histoire Naturelle Paris 6, 127.

DAwKInS, W.D. \& SANDFORT, A. 1900. A monograph of the British Pleistocene Mammalia. Volume I. The British Pleistocene Felidae. Palaeontographical Society Monographs 1866-1872, $1-194$.

DiEDRICH, C. 2004a. Ein Schädelfund und von Hyänen angenagter Oberschenkelknochen des Wollnashorns Coelodonta antiquitatis Blumenbach 1807 aus den pleistozänen Weserkiesen bei Minden (Norddeutschland). Philippia 11(3), 211-217.

DIEDRICH, C. 2004b. Oberpleistozäne Fleckenhyänenreste [Crocuta crocuta spelaea (Goldfuss, 1823)] aus Flussterrassenablagerungen in der Münsterländer Bucht (NW Deutschland). Philippia 11(3), 227-234.

DIEDRICH, C. 2004c. Freilandfunde des oberpleistozänen Höhlenlöwen Panthera leo spelaea Goldfuss, 1810 in Westfalen (Norddeutschland). Philippia 11(3), 219-226.

DiEDRICH, C. 2005a. Eiszeithyänen. Bisonknochen in der Kühlkammer. National Geographic Deutschland 2005(Mai), 9.

Diedrich, C. 2005b. Benagte und zerknackte Knochen des eiszeitlichen Pferdes Equus ferus przewalskii Poljakoff, 1881 aus einem oberpleistozänen Fleckenhyänenhorst des Nordsauerlandes und westfälischen Freilandfundstellen. Philippia 12(1), 47-62.

DIEDRICH, C. 2005c. Von eiszeitlichen Fleckenhyänen benagte Mammuthus primigenius (Blumenbach, 1799) -Knochen und -Knabbersticks aus dem oberpleistozänen Perick-Höhlenhorst (Sauerland) und Beitrag zur Taphonomie von Mammutkadavern. Philippia 12(1), 63-84.

DIEDRICH, C. 2005d. Von eiszeitlichen Fleckenhyänen eingeschleppte Reste des Steppenwisents Bison priscus Bojanus, 1827 aus dem oberpleistozänen Fleckenhyänenhorst des Perick-Höhlensystems (NW Deutschland). Philippia 12(1), 21-30.

DIEDRICH, C. 2005e. Von oberpleistozänen Fleckenhyänen gesammelte, versteckte, verbissene, zerknackte Knochen und Geweihe des Riesenhirsches Megaloceros giganteus (Blumenbach, 1799) aus den Perick-Höhlen im Nordsauerland (NW Deutschland). Philippia 12(1), 31-46.

DiEDRICH, C. 2005f. Eine oberpleistozäne Population von Crocuta crocuta spelaea (Goldfuss, 1823) aus dem eiszeitlichen Fleckenhyänenhorst Perick-Höhlen von Hemer (Sauerland, NW Deutschland) und ihr Kannibalismus. Philippia 12(2), 93-115.

DIEDRICH, C. 2005g. Cracking and nibbling marks as indicators for the Upper Pleistocene spotted hyena as a scavenger of cave bear (Ursus spelaeus Rosenmüller, 1794) carcasses in the Perick caves den of Northwest Germany. Abhandlungen der Naturhistorischen Gesellschaft Nürnberg 45, 73-90.

DiEDRICH, C. 2006a. Cave bear open air site remains and den caves from the Upper Pleistocene of Central Bohemia (Czech Republic). Abstract. 12 International Cave Bear Symposium, Aridéa/Loutrá (Greece) 2006, 35-36.

DiEDRICH, C. 2006b. By Ice Age spotted hyenas removed, cracked, nibbled and chewed skeleton remains of Coelodonta antiquitatis (Blumenbach 1799) from the Lower Weichselian (Upper Pleistocene) freeland prey deposit site Bad Wil- 
dungen-Biedensteg (Hessia, NW Germany). Journal of Taphonomy, in press.

DIEDRICH, C. 2006c. The Crocuta crocuta spelaea (Goldfuss 1823) population from the Upper Pleistocene hyena freeland prey deposit site Biedensteg near Bad Wildungen (Hess, NW Germany) and contribution to their coprolites. Cranium, in press.

DiEDRICH, C. 2006d. Ice Age spotted hyenas ?hunting or only scavenging on a female cave bear Ursus spelaeus Rosenmüller at the Crocuta crocuta spelaea Goldfuss freeland den and prey deposit site Bad Wildungen-Biedensteg (Hessia, Germany). Abstract. 12 International Cave Bear Symposium, Aridéa/Loutrá (Greece) 2006, 33-34.

DIEDRICH, C. Accepted a. Von oberpleistozänen Fleckenhyänen benagte Geweihe und Knochen des Rothirsches Cervus elaphus (Linné, 1758) aus den Perick-Höhlen (NW Deutschland). Philippia, accepted.

DiEDRICH, C. Accepted b. Von eiszeitlichen Fleckenhyänen angenagte Geweihe und vom Vielfraß eingeschleppte Kadaverreste von Rangifer tarandus Linné, 1758 aus dem PerickHöhlensystem von Hemer im Sauerland (NW Deutschland). Philippia, accepted.

Di Silvestre, I., Novelli, O. \& Bogliani, G. 2000. Feeding habits of the spotted hyaena in the Niokolo Koba National Park, Senegal. African Journal of Ecology 38, 102-107.

EAST, M.L., HofER, H. \& TÜRK, A. 1989. Functions of birth dens in spotted hyaenas (Crocuta crocuta). Journal of Zoology London 219, 690-697.

FEJfAR, O. 1956a. Zpráva o výzkumu pleistocénních ssavců v roce 1954. Anthropozoikum 5, 359-362.

FEJFAR, O. 1956b. Seznam druhů fosilních savců z jeskyně C 718 na Zlatém koni u Koněprus. Věstník Ústředního ústavu geologického v Praze 31, 274-276.

FEJFAR, O. 1958. Einige Beispiele der Benagung fossiler Knochen. Anthropozoikum 7, 145-149.

FEJFAR, O. 1961a. Review of Quaternary Vertebrata in Czechoslovakia. Prace Instytutu geologicznego 34, 103-118.

FEJFAR, O. 1961b. Výsledky výzkumu fossilních obratlovců. Zprávy o geologických výzkumech v roce 1960, 170-172.

FEJFAR, O. 1964. Výzkum fosilních obratlovců v ČSSR v roce 1963. Zprávy o geologických výzkumech v roce 1963(1), 350-352.

FEJFAR, O. 1966. Výzkum fosilních obratlovců. Zprávy o geologických výzkumech $v$ roce 1964(1), 375-376.

FeJfAR, O. 1973. Fosilní savci v krasu Československa. Geologický průzkum 7, 213-215.

FeJfar, O. \& HeInRICH, W.-D. 1983. Arvicoliden. Sukzession und Biostratigraphie des Oberpliozäns und Quartärs in Europa. Schriftenreihe für Geologische Wissenschaften, $H$. 19/20, 61-109.

Fejfar, O., HorÁČek, I., Čermák, S., \& Wagner, J. 2004. Shrnutí současného stavu poznání stáří sedimentární výplně středního patra Koněpruských jeskyní na základě studia fosilních savců. In IvANOV, M. \& ÁBELOVÁ, M. (eds) Sborník přispěvkủ 10. kvartér 2004. Masaryk University, Brno.

FOSSE, P. 1999. Cave occupation during Palaeolithic times: man and/or hyena?, 73-87. In TURNER, E. \& GAUDZINSKI, S. (eds) The role of Early humans in the accumulation of European Lower and Middle Palaeolithic Bone Assemblages. Habelt, Mainz.

Fosse, P., Brugal, J.P., Guadelli, J.L., Michel, P. \& Tour-
NEPICHE, J.F. 1998. Les repaires d' hyenes des cavernes en Europe occidentale: presentation et comparisons de quelques assemblages osseux, 44-61. In BRUgal, J.-P., MEIGnEN, L. \& Patou-Mathis, M. (eds) Economie préhistorique: les comportements de substance au Paléolithique. XVIII Rencontres internationales d'Archeologie et d'Historie d'Antibes 18, Editions APDCA, Sophia-Antipolis.

FRANK, L.G. 1986a. Social organization of the spotted hyaena (Crocuta crocuta). I. Demography. Animal Behavior 34, 1500-1509.

FRANK, L.G. 1986b. Social organization of the spotted hyaena Crocuta crocuta. II. Dominance and reproduction. Animal Behavior 34, 1510-1527.

FrANK, L.G. 1994. When hyenas kill their own. New Scientist 141, 38-41.

FRIČ, A. 1875. Untersuchung über die Dvoretzer Höhle bei Prag. Sitzungsberich der königlich böhmischen Gesellschaft der Wissenschaften 1875, 151-153.

FRIČ, A. 1876. Prabydlitelé země české. Vesmír 5, 27-28.

FRIDRICH, J. \& SKLENÁŘ, K. 1976. Die Paläolitische und Mesolitische Höhlenbesiedlung des Böhmisches Karstes. Fontes Archeologici Pragenses 16, 1-120.

Gross, C. 1992. Das Skelett des Höhlenlöwen (Panthera leo spelaea Goldfuss, 1810) aus Siegsdorf/Ldkr. Traunstein im Vergleich mit anderen Funden aus Deutschland und den Niederlanden. 129 pp. PhD thesis. Veterinary Faculty, Maximilians-University, Munich, Germany.

HájeK z LibočAn, V. 1541. Kronika česká. Výbor historického čtení. 736 pp. J. Kolár (ed.), Odeon, Praha 1981.

Heller, F. 1960. Höhlen-Hyänen-Reste aus jungdiluvialen Ablagerungen Westfalens. Abhandlungen des Landesmuseums für Naturkunde Münster 22(3), 3-8.

HELLER, F. 1962. Hyänenfraß-Reststücke von Schädeln des Wollhaarigen Nashorns Coelodonta antiquitatis Blumenbach. Quartär 14, 89-93.

Henschel, J.R., Tilson, R. \& Von Blottnitz, F. 1979. Implications of a spotted hyaena bone assemblage in the Namib Desert. South African Archaeological Bulletin 34, 127-131.

HofER, H. \& EAST, M. 1995. Population dynamics, population size, and the commuting system of Serengeti spotted hyenas, 332-363. In Sinclair, A.R.E. \& ARCeSe, P. (eds) Serengeti II: Dynamics, Management, and Conservation of an Ecosystem. University of Chicago Press, Chicago.

Homola, V. 1945. Nová jeskyne na Chlumu u Srbska. Sborník České společnosti zeměpisné 50, 93-95.

HoRÁČEK, I. 1976. Přehled kvartérních netopýrů (Chiroptera) Československa. Lynx, n.s., 18, 35-58.

HORÁČEK, I. 1979. Výplně 4. sluje na Chlumu u Srbska a jejich význam pro kvartérní stratigrafii. Český kras 4, 19-34.

HORÁČEK, I. 1982. Výzkum fosilních obratlovců v CHKO Český kras. Památky a přiroda 1982, 106-111.

HoRÁČEK, I. 1984. Obratlovčí mikrofauna z fosilních výplní Koněpruských jeskyní (Review of the vertebrate microfauna from the Koněprusy Caves). Český kras, 9, 68-75.

HORÁČEK, I. 1990. On the community context of the arvicolid Quaternary evolution, 201-222. In FEJFAR, O. \& HEINRICH, W.-D. (eds) International Symposium Evolution, Phylogeny and Biostratigraphy of Arvicolids (Rodentia, Mammalia). Czech Geological Survey, Prague. 
HoRÁČEK, I. 2000. Nálezy mladocenozoické fauny v Českém krasu a jejich význam pro poznání morfogeneze této oblasti, 40-48. In CíleK, V. \& BosÁK, P. (eds) Zlatý kůñ. Knihovna České speleologické společnosti, svazek 36. Česká speleologická společnost, Praha.

HorÁČEK, I. \& LOŽEK, V. 1988. Palaeozoology and the MidEurpean Qaternary past: scope of the approach and selected results. Rozpravy Československé akademie věd, $\breve{R} a d a$ matematických a př́rodních věd 98(4), 1-102.

KAFKA, J. 1890. Jeskyně svatoprokopská. Vesmir 19, 145-146.

KAFKA, J. 1892a. Člověk pravěký v Čechách. Vesmír 21, 253-254.

KAFKA, J. 1892b. Hlodavci země české žijící i fossilní. Archiv pro přirodovědecký výzkum Čech 8(5), 1-96.

KAFKA, J. 1893. Turecká či Turská Maštal pod Tetínem. Vesmír 22, 208-210.

Kafka, J. 1900. Šelmy (Carnivora) země české, žijící i fosilní. Archiv pro přirodovědecký výzkum Čech 10(6), 1-104.

KAFKA, J. 1903. Fossile und Recente Raubthiere Böhmens (Carnivora). Archiv der Naturwissenschaftichen Landesdurchforschung von Böhmen 10(6), 1-124.

KAFKA, J. 1909, 1916. Kopytníci země české žijící a vyhynulí. Archiv pro přirodovědecký výzkum Čech, Oddíl I 1909, 14(5), 1-66; Oddíl II 1916, 16(3), 1-79.

Keller, T. \& FöRSTERLING, G. 2002. Unterbrochene Mahlzeit? Eiszeitliche Knochenfunde aus dem Gipskarst von Morschen-Konnefeld, 18-21. In Archäologische und Paläontologische Bodendenkmalpflege des Landesamtes für Denkmalpflege Hessen (ed.) Hessen Archäologie 2002, Stuttgart.

KLEIN, R.G. \& CRUZ-URIBE, K. 1984. The analysis of animal bones from archaeological sites. 266 pp. University of Chicago Press, Chicago.

Koenigswald, W. vON 1983. Die Säugetierfauna des süddeutschen Pleistozäns, 167-216. In MÜLLER-BECK, H. (ed.) Urgeschichte in Baden-Württemberg. Stuttgart.

KolČAva, M. 2005. Fialová jeskyně na Chlumu. Český kras 31, $22-24$.

KovANDA, J. 1973. Výzkumy výplně Chlupáčovy sluje u Koněprus. Sborník geologických věd, Antropozoikum 9, 131-148.

KovAnDA, J. 2002. Jaroslav Petrbok a objev Koněpruských jeskyní. Český kras 28, 19-26.

KOŘENSKÝ, J. 1876. Geologické vycházky po okoli smíchovském. 24 pp. České školy na Smíchově, Praha.

KoŘENSKÝ, J. 1883a. O diluviální zvířeně jeskyně Svatoprokopské. Zprávy královské české společnosti nauk 1883, 229-230.

KoŘENSKÝ, J. 1883b. V údolí Svatoprokopském. Vesmír 12, 219-223.

KOŘENSKÝ, J. 1888. O nových osteologických nálezech z jeskyně svatoprokopské. Měsíčni zprávy o činnosti královské české společnosti nauk, leden 1888, 30.

KOŘENSKÝ, J. 1890. Jeskyně svatoprokopská, 55-60, 190-191, 644. In HANZL, F. (ed.) Smíchovsko a Zbraslavsko. Fr. Hanzl, Smíchov.

KRUUK, H. 1970. Interactions between populations of spotted hyaenas (Crocuta crocuta Erx.) and their prey species, 359-374. In WATson, A. (ed.) Animal populations in relation to their food resources. Blackwell, Oxford.

KRUUK, H. 1972. The spotted hyena. A story of predation and social behavior. 335 pp. The University of Chicago Press, Chicago.
KUČERA, B. 1985. Jeskyně skupiny 23 v Českém krasu. Československý kras 36, 26-61.

KuČERA, B., HROMAS, J., \& SKŘIVÁNEK, F. 1981. Jeskyně a propasti $v$ Československu. 252 pp. Academia, Praha.

KuKLA, J. 1952. Zpráva o výsledcích výzkumů jeskyní na Zlatém koni u Koněprus v roce 1951, prováděných Krasovou sekcí Přírodovědeckého klubu v Praze. Československý kras 5, 49-68.

KuKLA, J. 1953. Výplně kapes na Zlatém koni. 85 pp. Master thesis, Faculty of Science, Charles University, Prague, Czech Republic.

KUŽELKA, V. 1997. The postcranial skeletal remains of Pleistocene man from Zlatý kủň near Koněprusy (Bohemia). Anthropologie 35(3), 247-249.

Leroi-Gourhan, A. 1965. Préhistoire de l'art occidental. 482 pp. Citadelle/Mazenod.

LIEBE, K.T. 1876. Die Lindentaler Hyänenhöhle und andere diluviale Knochenfunde in Ostthüringen. Archiv des Anthropologischen Organs der deutschen Gesellschaft für Anthropologie, Ethnographie und Urgeschichte 9, 155.

LoRblanchet, M. 1995. Les grottes ornées de la Préhistoire. 288 pp. Nouveaux regards, Errances.

LOŽEK, V. 2000. Malakostratigrafie kvartéru koněpruské oblasti, p. 22-40. In CílEK, V. \& BosÁK, P. (eds) Zlatý kůň. Knihovna České speleologické společnosti, svazek 36. Česká speleologická společnost, Praha.

LYSENKO, V. 1976. Př́ispěvek ke stratigrafii sedimentů v Koněpruských jeskyních. Český kras 1, 18-27.

MACH, V. 1951. Objev nejkrásnější české krápníkové jeskyně v pražském okolí. Vesmír 29(5), 114-115.

MatoušEK, V., Beneš, J., LOŽEK, V. \& HoRÁČEK, I. 1985. Zpráva o 1. sezóně archeologického výzkumu na Axamitově bráně. Český kras 11, 7-35.

MosteCKÝ, V. 1961. Pleistocenní savci z „Chlupáčovy sluje“ na Kobyle u Koněprus (Berounsko). Časopis Národního muzea 130(1), 22-25.

MosteCKÝ, V. 1963. Der pleistozäne Bär Ursus taubachensis RODE aus der Schlucht „Chlupáčova sluj“ bei Koněprusy. Sborník Národního muzea 19B(2), 75-101.

MosteCKÝ, V. 1964. Pleistozäne Säugetiere aus dem Steinbruch auf "Chlum". Sborník Národního muzea 20B, 153-186.

MosteckÝ, V. 1966. Rhinocerotidae aus der Höhle "Chlupáčova sluj” bei Koněprusy. Sborník Národního muzea 22B(4), $143-161$.

MosteCKÝ, V. 1969. Jungpleistozäne Säugetiere der "ChlupáčHöhle" auf Hüger "Kobyla" bei Koněprusy (Böhmischer Karst). Sborník Národního muzea v Praze 25B(1), 1-55.

PetrвoK, J. 1920. Měkkýši Turské maštale u Tetína. Časopis Muzea království českého 94, 118-121.

PetrboK, J. 1932. Nejnovější výsledky z výzkumu „Turských maštalí“ u Tetína. Časopis Národního muzea, Oddíl př́rodovědný 106, 157-158.

PetRBoK, J. 1938a. První nález Machairoda v českém plistocénu. Př́roda 31, 296-297.

PetRBoK, J. 1938b. Trogontherium sp. cf. cuvieri Fischer v českém plistocénu. Př́roda 31, 241-242.

PetrBoK, J. 1939a. Equus caballus sp.? cf. robustus Pommel z trogontheriové fauny u Srbska nad Berounkou. Př́roda 32, 76-77.

Petriok, J. 1939b. Ursus sp. cf. spelaeus v trongotheriové vrstvě u Srbska. Př́roda 32(9), 317-318. 
PetrboK, J. 1939c. Význam jeskyní na Chlumu pro určení stáří Českého krasu. Př́roda 32, 243.

PetRBOK, J. 1940a. Rys (Lynchus lynx L.) v. trongotheriové fauně na Chlumu u Srbska. Př́roda 33, 249.

PetrioK, J. 1940b. Nově objevená paleolitická stanice jeskyně Nad Kačákem u Srbska nad Berounkou. Př́roda 33 (2), 169-176.

PetRBoK, J. 1941. Sus scrofa ferus v českém riss-würmu. Př́roda 34, 188-189.

PetrioK, J. 1942. Čtvrtá sluj jeskyně na Chlumu u Srbska (Zpráva předběžná). Zprávy Geologického ústavu pro Čechy a Moravu $17,97-100$.

Petriok, J. 1943a. Pátá sluj jeskyně na Chlumu u Srbska. Sborník české společnosti zeměpisné 48, 85-86.

PetrioK, J. 1943b. Stopy po hlodání Trogontheria na kostech z jeskyní Českého krasu. Př́roda 35, 31.

PetrBoK, J. 1944a. Lepus sp. v trongotheriové fauně IV sluje na Chlumu u Srbska. Přiroda 36, 137.

PetrboK, J. 1944b. Stratigrafická chronologie paleolitických vrstev ,Jeskyně nad Kačákem“. Rozpravy II. tř́dy České akademie věd 53(2), 1-16.

PetrboK, J. 1947. Paleolitický nález ve „Čtvrté sluji“ kopce Clumu u Srbska. Časopis Národního muzea, Oddíl duchovědný 116(1), 21-26.

PetrboK, J. 1950a. Noví měkkýši českého plistocenu z tzv. „Chlupáčovy sluje“ u Koněprus. Československý kras 3, 262.

PetrioK, J. 1950b. Paleolithikum v Turských maštalích u Berouna v Čechách. Československý kras 3, 254-255.

PetrboK, J. 1952. „Chlupáčova sluj“ u Koněprus. Lidé a Země 1(3), 90-95.

PetrboK, J. 1953. Kostěné podložky paleolitické z „Prvni sluje“ na kopci Chlumu u Srbska nad Berounkou. Anthropozoikum 3, 325-226.

PetrboK, J. 1954. Profil na stráni u Chlupáčovy sluje na Kobyle. Československý kras 7, 140-141.

PetrioK, J. 1956. Český kras ve výzkumu do roku 1950. Anthropozoikum 5, 9-46.

PICKERING, T.R. 2002. Reconsideration of criteria for differentiating faunal assemblages accumulated by hyenas and hominids. International Journal of Osteoarchaeology 12, 127-141.

Píč, J.L. 1891. Archaeologický výzkum ve středních čechách II. Jeskyně „Turské maštale“ pod Tetínem. Památky archeologické 15, 383-388.

PROŠEK, F. 1947. Paleolitické osídlení Čech ve světle novějších výzkumů. Časopis Národního muzea, Oddíl duchovědný 66, 11.

REYNOLDS, S.H. 1902. A monograph of the British Pleistocene Mammalia. Volume II, Part II. The Cave Hyena. Palaeontological Society Monographs 1902, 1-25.

SCHUBERT, R.J. 1900. Ueber eine neu entdeckte Höhle bei Konieprus (Beraun). Lotos, Neue Folge 20, 247-250.

SCHÜtT, G. 1978. Zur Evolution des Löwen (Panthera leo L.) im europäischen Pleistozän. Neues Jahrbuch für Geologie und Paläontologie, Monatshefte 4, 228-255.

SCOTT, L. \& KLEIN, R.G. 1981. A hyena accumulated bone assemblage from late holocene deposits at Deelpan, Orange Free State, South Africa. Annals of the South African Museum 86, 217-227.

Skinner, J.D., Henschel, J.R. \& VAN JAARSVEld, A.S. 1986. Bone-collecting habits of spotted hyaenas Crocuta crocuta in the Kruger National Park. South African Journal of Zoology 21, 303-308.

SKLENÁR̆, K. 1991. Kdo byl Lothar Zotz. Speleo 16, 16-20.

SKřIVÁNEK, F. 1954. Jeskyně na Chlumu v Českém krasu. Československý kras 7, 25-34.

SKŘIVÁNEK, F. \& LOŽEK, V. 1953. Šestá sluj na Chlumu u Srbska. Československý kras 6, 63-65.

SKUTIL, J. 1952a. Ještě k domněle pleistocenním anthropologickým nálezům ze Svatoprokopské jeskyně u Prahy. Československý kras 5, 76-78.

SkUTIL, J. 1952b. Pražská jeskyně v Podolí-Dvorcích. Československý kras 5, 211-213.

SkUTIL, J. 1953. Ještě k otázce domněle pleistocenního stáří antropologických nálezů ze Svatoprokopské jeskyně u Prahy. Československý kras 6, 68.

SoERGEL, W. 1937. Die Stellung der Hyaena spelaea Goldf. aus der Lindentaler Hyänenhöhle bei Gera. Beiträge zur Geologie von Thüringen 4(5), 171-189.

StÁrka, V., ProšeK, F., HrdličKa, L., Hokr, Z., LOŽEK, V. \& DoHNAL, Z. 1952. Výzkum jeskyně Zlatého koně u Koněprus. Zpráva za I. výzkumné období r. 1951. 2. část. Československý kras 5, 161-179.

STEHLíK, A. 1935. Nález Equus cf. hemionus foss. Nehring z jeskyně Kačáku u Prahy. Př́roda 28, 10.

STINER, M.C. 1991. Food procurement and transport by human and non-human predators. Journal of Archaeological Science $18,455-482$.

STINER, M.C. 1994. Honour among thieves: a zooarchaeological study of Neandertal ecology. 447 pp. Princeton University press, Princeton.

SuTCLIFFE, A.J. 1970. Spotted Hyena: crusher, gnawer, digester and collector of bones. Nature 227, 110-113.

SvobodA, J. 2000. The depositional context of the Early Upper Paleolithic human fossils from the Koněprusy (Zlatý kůň) and Mladeč Caves, Czech Republic. Journal of Human Evolution 38, 523-536.

Svoboda, J.A., Plicht, J. van DER \& KuŽELKA, V. 2002. Upper Palaeolithic and Mesolithic human fossils from Moravia and Bohemia (Czech Republic): some new ${ }^{14} \mathrm{C}$ dates. Antiquity 76, 957-962.

SvobodA, J.A., KuŽElKA, V. \& VLČEK, E. 2003. Koněpruské jeskyně: nálezová situace lidského skeletu a první radiokarbonové datování. 278-284. In HAŠEK, V., NEKUDA, R. \& UnGER, J. (eds) Ve službách archeologie, Sborník k 75. narozeninám Prof. PhDr. Vladimíra Nekudy, DrSc. Muzejní a vlastivědná společnost v Brně, Brno.

Svoboda, J.A., VAN deR Plicht, J., VlČEK, E. \& KuŽElKa, V. 2004. New radiocarbon datings of human fossils from caves and rockshelters in Bohemia (Czech Republic). Anthropology 42(2), 161-166.

Tournepiche, J.-F., Couture, C., Guadelli, J.-L. \& Michel, P. 1996. Les restes neandertaliens du repaire d'hyènes de la grotte de Rochelot (Saint-Amant-de-Bonnieure, Charente, France). Paleontologie Humaine 332(2a), 429-435.

TYRÁČEK, J. 2001. Upper Cenozoic fluvial history in the Bohemian Massif. Quaternary International 79, 37-53.

TYRÁČEK, J., WESTAWAY, R. \& BRIDLAND, D. 2004. River terraces of the Vltava and Labe (Elbe) system, Czech Republic, and their implications for the uplift history of the Bohemian 
Massif. Proceedings of the Geologists' Association 115, 101-124.

Vencl, S. 1995. Hostim - Magdalenian in Bohemia. Památky archeologické, Supplementum 4, 1-264.

VLČEK, E. 1952a. Nález pleistocenního člověka v jeskyních Zlatého koně. 3. část. Československý kras 5, 180-191.

VLČEK, E. 1952b. Pleistocenní člověk z jeskyně Sv. Prokopa. Anthropozoikum 1, 213-226.

VLČEK, E. 1952c. První nález pleistocenního člověka v Českém krasu. Československý kras 5, 2-9.

VLČEK, E. 1952d. Důkaz pleistocenního stáří svatoprokopského nálezu. Československý kras 5, 139-140.

VLČEK, E. 1957. Pleistocenní člověk z jeskyně na Zlatém koni u Koněprus. Anthropozoikum 6, 283-311.

WAGNER, J. 2003. Taxonomické určení nálezů rodu Ursus (Mammalia, Ursidae) z vybraných biharských lokalit České a Slovenské republiky. 133 pp. Master thesis, Institute of Geology and Palaeontology, Faculty of Science, Charles University, Prague, Czech Republic.

Werdelin, L. \& Solounias, N. 1991. The Hyaenidae: Taxonomy, systematics and evolution. Fossils and Strata 30, 1-104.

WERNERT, P. 1968. Beutestücke der Höhlenhyänen im anatomischen Verband aus Achenheimer Lössen. Quartär 19, 55-64.

WoldřICH, J.N. 1893. Fossilní zvířena „Turské Maštale“ u Berouna v Čechách a rozsedliny louvérneské ve Francii. Rozpravy České akademie pro vědy, slovesnost a umění, Tř́ida II 2(15), 1-16.
WOLDřICH, J.N. 1889. Beiträge zur Urgeschichte Böhmens. Mitteilungen der Antropologischen Gesellschaft Wien 19, 72-108.

WolDřICH, J.N. 1919. Das Prokopital südlich von Prag. Jahrbuch der kaiserlich-königlichen geologischen Reichsanstalt A68, 64-112.

ZÁzvorka, V. 1954. Pažní kost lva jeskynního - Panthera (Leo) spealaea, Goldfuss - z „Chlupáčovy sluje“ na Kobyle u Koněprus (Berounsko). Časopis Národního muzea 123(2), $168-175$.

ŽÁK, K., KolČAvA, M., JÄGER, O. \& ŽIVOR, R. 2005. Evidence jeskyní Českého krasu - stav k 1. říjnu 2005. Český kras 31, 19-21.

ŽÁK, K., TÁBORSKÝ, Z., KADLEC, J. \& CíleK, V. 2004a. Jeskynní sedimenty a vývoj krasových jevů v údoli řeky Berounky $v$ Českém krasu. Unpublished project report. Archive of the Czech Geological Survey, Prague.

ŽÁK, K., Urban, J., Cílek, V. \& Hercman, H. 2004b. Cryogenic cave calcite from several Central European caves: age carbon and oxygen isotopes and a genetic model. Chemical Geology 206, 119-136.

Žák, K., TÁborský, Z., Kadlec, J., Cílek, V., Hercman, H., OSBORNE, R.A.L., BrUTHANS, J., VYSOKÁ, H. \& TEODORIDIS, V. Submitted. Vývoj říční sítě a vznik jeskyní Českého krasu. Czech Geological Survey Special Papers.

ZoTZ, L.F. 1942. Die Nachausgrabung der Katschakhöhle. Nachrichtenblatt für Deutsche Vorzeit 17, 233-237. 